NICOLE SCASSIOTTA NEVES

\title{
PLANEJAMENTO NORMATIVO DO TRANSPORTE COLETIVO POR ÔNIBUS NA REGIÃO METROPOLITANA DE SÃO PAULO
}

Dissertação apresentada à Faculdade de Direito da Universidade de São Paulo como requisito para obtenção do título de Mestre em Direito.

Professor Orientador: José Maria Arruda de Andrade

SÃO PAULO

2014 
Aos meus pais e à minha irmã, com amor e gratidão, pela paciência e incansável apoio ao longo dos anos de estudo. 
Agradeço primeiramente aos meus pais Ana Cleide e Walter, pelo amor e paciência, não apenas no período consumido na produção deste trabalho, mas em todas as etapas de nossas vidas.

Também registro minha gratidão e carinho à minha querida irmã Natália pela infindável compreensão nos momentos mais difíceis de estudo e dedicação.

Sou grata igualmente ao meu estimado orientador, Dr. José Maria Arruda de Andrade, que nos anos de convivência muito me ensinou.

Agradeço aos Professores Antônio Cláudio Moreira Lima e Moreira e Luís Fernando Massonetto, pelas críticas ao longo do trabalho que foram essenciais para o desenvolvimento desta dissertação.

Não posso deixar de registrar meu agradecimento aos meus queridos amigos Paula Santana Pimenta, Claudia Monteiro de Barros Ruic e Rafael Stefani, pelo afetuoso apoio ao longo dos anos.

Por fim, agradeço aos professores Heitor Vitor Mendonça Sica, Ligia Pires Pinto Sica e Anna Lygia Costa Rego, pela inspiração e por todo o incentivo ao longo dos anos para alcançar o objetivo de cursar o mestrado. 


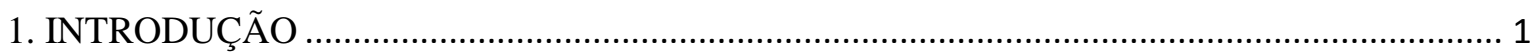

2. BREVES NOTAS SOBRE DESENVOLVIMENTO SUSTENTÁVEL_......................................... 4

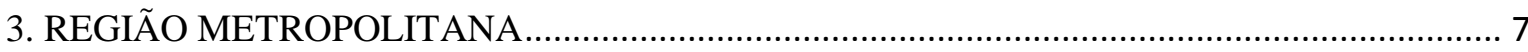

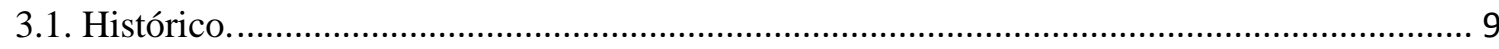

3.1.1. As Constituições de 1937, 1946 e 1967 e a Emenda Constitucional 1/1969................. 10

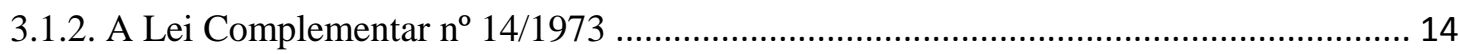

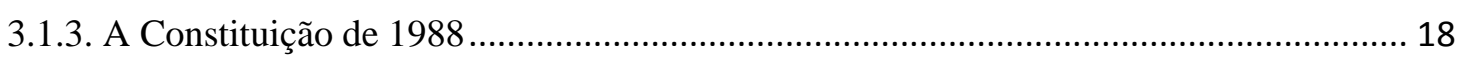

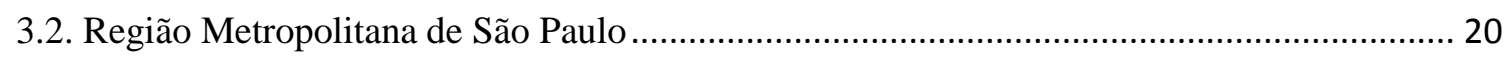

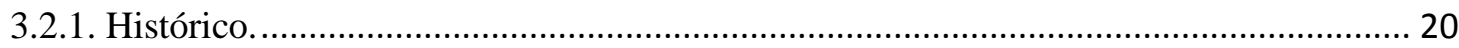

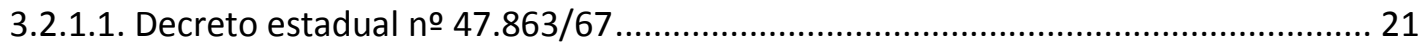

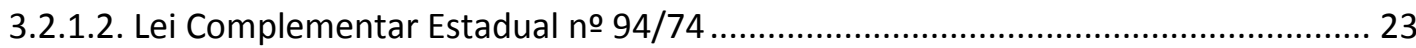

3.2.1.3. Decreto Estadual № 6.111/75, Lei Complementar Estadual no 144/1976 e Lei

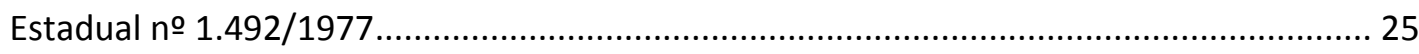

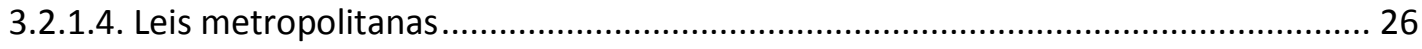

3.2.1.5. A Constituição Estadual e os contornos modernos da Região Metropolitana de São

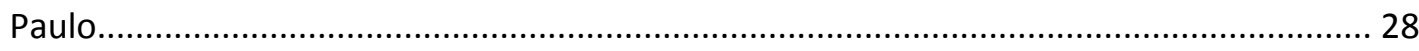

3.2.1.6. Lei Complementar Estadual no 760/94 ……….................................................... 31

3.2.1.7. O transporte coletivo na Região Metropolitana de São Paulo ................................. 32

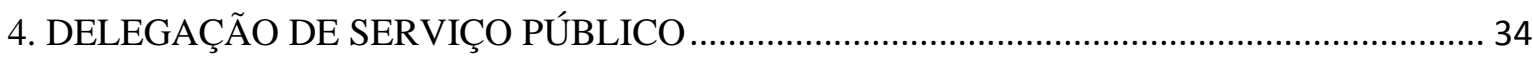

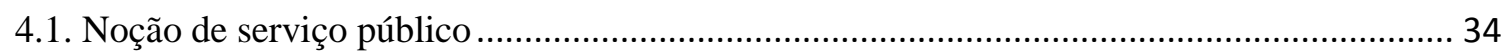

4.2. Evolução no Brasil da ideia de delegação de serviços públicos a particulares ...................... 35

4.3. Serviços delegados a particulares na dicção da Constituição de 1988 ................................... 36

4.3.1. Concessão de Serviço Público ................................................................................... 39

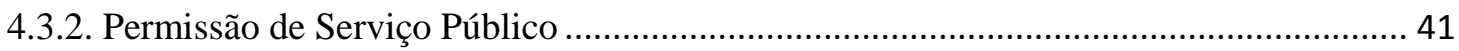

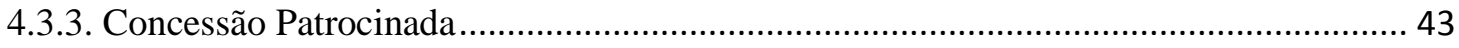

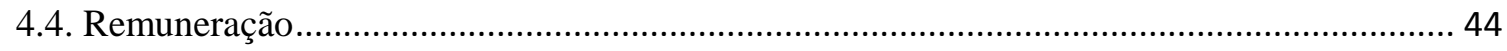




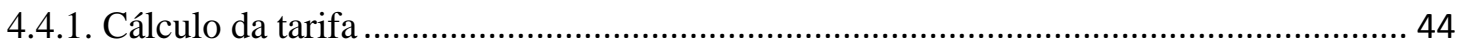

4.4.3. Sistemas de tarifação no transporte público ...................................................................... 45

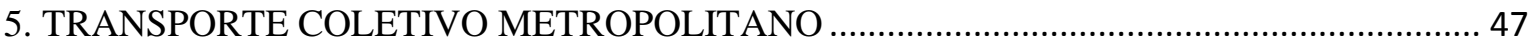

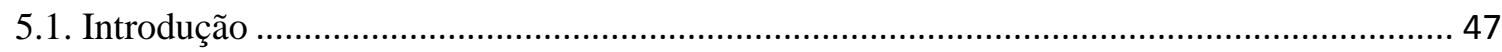

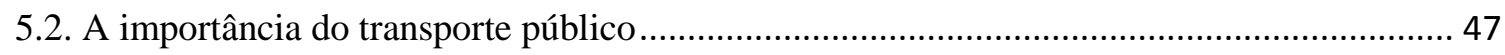

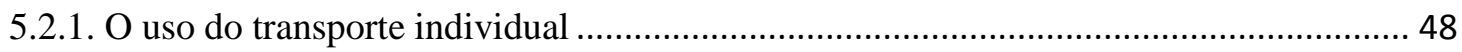

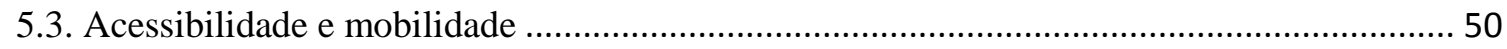

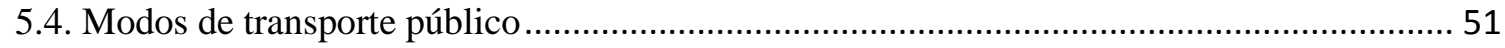

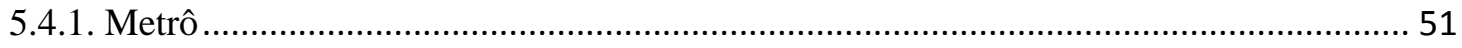

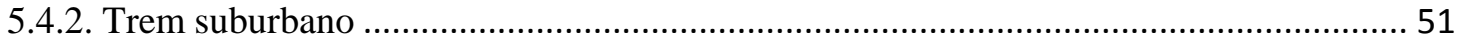

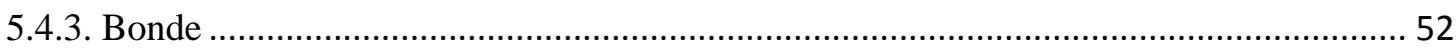

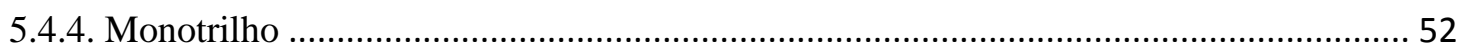

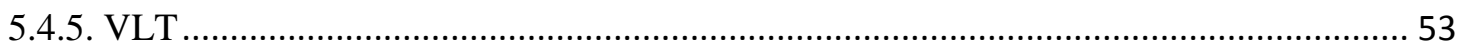

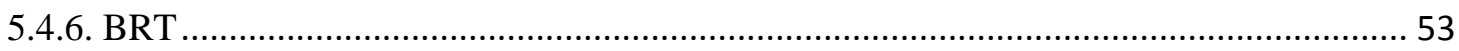

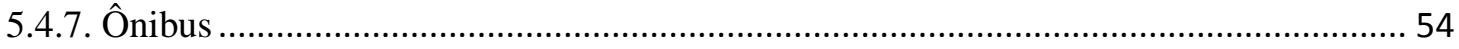

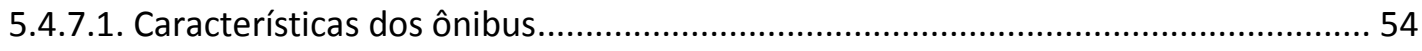

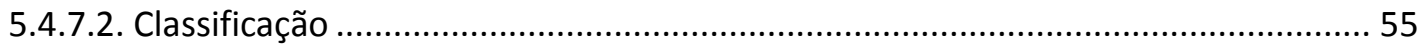

5.4.7.3. Corredores e Faixas Exclusivas de Ônibus............................................................ 56

6. DELEGAÇÃO DE SERVIÇOS DE TRANSPORTE NA RMSP …….................................... 58

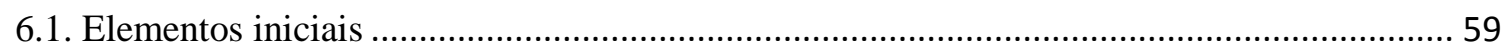

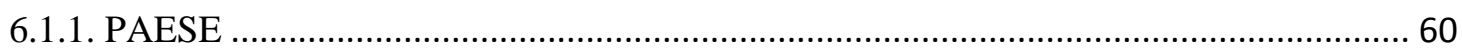

6.1.2. ORCA e Reserva Técnica Operacional ......................................................................... 60

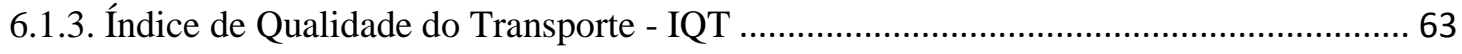

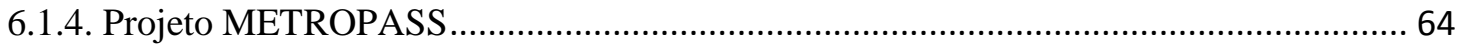

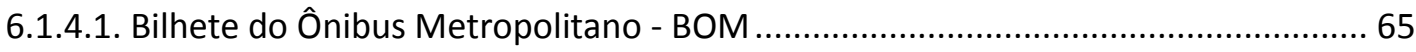

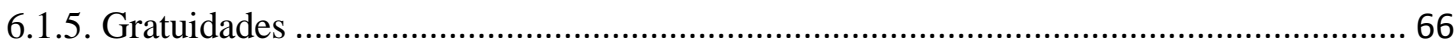

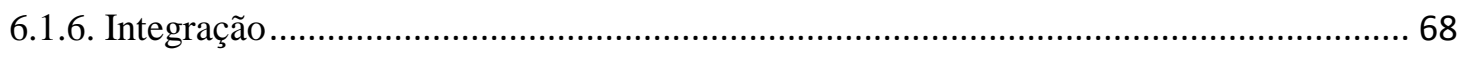




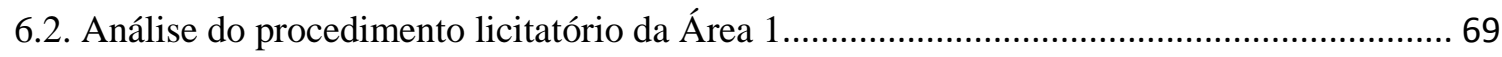

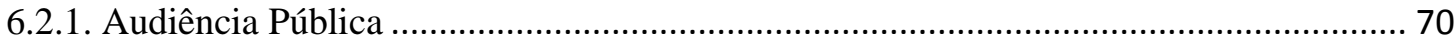

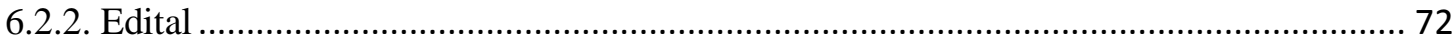

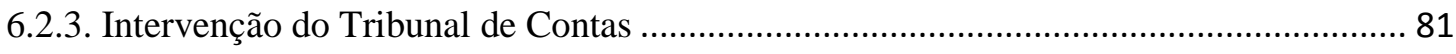

6.2.4. Compromisso de Constituição de Consórcio .................................................................. 82

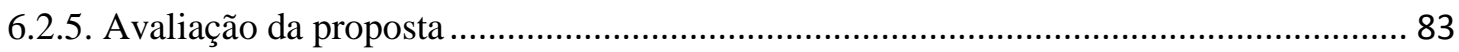

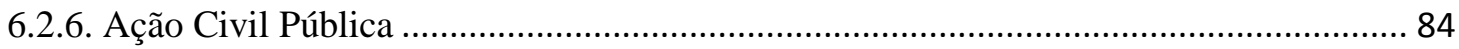

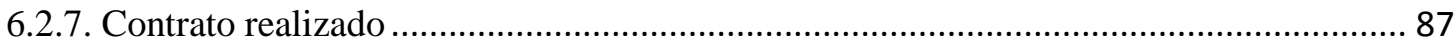

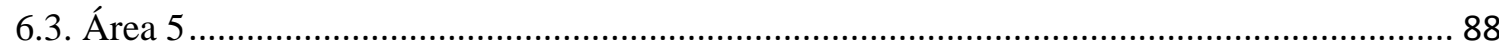

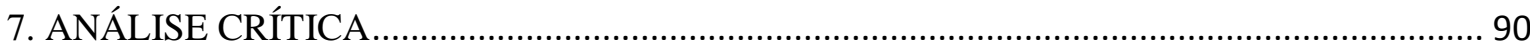

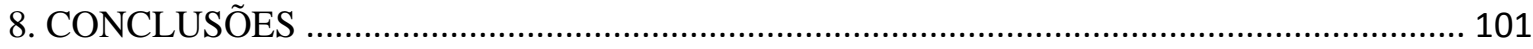

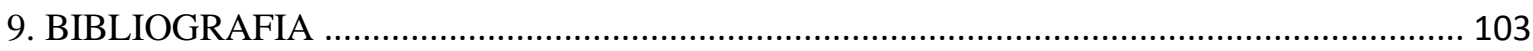

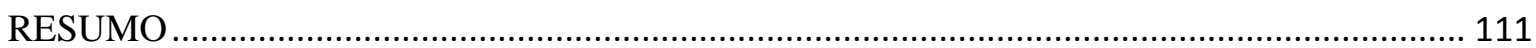

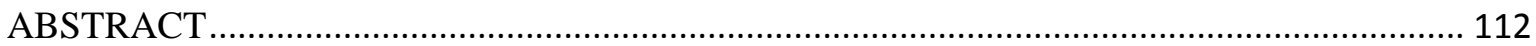




\section{INTRODUÇÃO}

A problemática do transporte público por ônibus na Região Metropolitana de São Paulo é de grande relevância, podendo ser observada todos os dias pelos noticiários do país. Em 2012, o Sistema Metropolitano por ônibus da região transportou 573,6 milhões de passageiros, representando um acréscimo de $2 \%$ em relação ao ano de $2011^{1}$. O número de passageiros ao longo dos anos aumentou consideravelmente, ainda que o sistema conviva com outros modais de alta e média capacidade, como o trem e o metrô.

Acrescido a este fato, nota-se ao longo dos anos igualmente um aumento nos congestionamentos nas vias da região e uma constante demanda pública para a resolução da questão da mobilidade. No ano de $2013^{2}$, um fato tornou-se referência para a discussão do tema: os protestos iniciados em junho a partir do anúncio pela Prefeitura Municipal de São Paulo do aumento da passagem do ônibus municipal que passaria de três reais para o custo de três reais e vinte centavos, um aumento de aproximadamente sete por cento, inferior à inflação observada nos últimos anos sem reajuste da tarifa. O referido protesto não possuiu qualquer liderança identificável e teve início a partir de eventos marcados pelas redes sociais.

Essa queixa de caráter geral teve como principais objetivos a melhoria do transporte público, com a redução das tarifas propostas, a desaprovação da corrupção que aparenta reinante nos meios políticos e maiores investimentos nas áreas de saúde e educação. Tais manifestações se iniciaram em São Paulo e no Rio de Janeiro e se espalharam por todo o país.

Muitos profissionais comentaram os fatos e pode-se observar até certo ponto a concordância das análises de que o aumento de vinte centavos não seria o motivo principal para a indignação da população, mas foi, sim, o ápice da situação: verifica-se que muito se esperava a partir da redemocratização e dos novos paradigmas instaurados com a

\footnotetext{
1 Monitoramento da demanda 2009-2012: Evolução dos passageiros transportados nas Regiões Metropolitanas de São Paulo, Campinas e Baixada Santista, por modo de transporte, 2009-2012. Acessado em 06/01/2014 pelo site: http://www.stm.sp.gov.br/images/stories/publicacoes/demanda_2009_2012.pdf

2 Vide as pesquisas realizadas à época pelo IBOPE e sintetizadas no infográfico disponível em http://www.mundosustentavel.com.br/2013/08/infografico-entenda-as-manifestacoes-populares-dejunho2013/, acessado em 13/01/2014.
} 
Constituição de 1988, como melhores condições de saúde, educação, saneamento e transporte.

Apesar da qualidade de vida da população ter avançado consideravelmente ao longo dos anos, a convivência na maior cidade da América Latina de discrepâncias sociais, na qual habitam no mesmo espaço urbano indivíduos com vasto patrimônio e outros sem qualquer garantia de alimentação do dia, é revoltante a toda a sociedade, que não deve se conformar com tal realidade. Além disso, a população como um todo paga uma vasta quantidade de tributos, porém não observa o retorno desse investimento na forma esperada, já que as tarifas de transporte crescem e, por outro lado, a qualidade do serviço prestado e as condições físicas das ruas e avenidas, tanto em relação à pavimentação, quanto em relação aos pontos de parada de ônibus, não são satisfatórios.

Evidentemente, no evento de junho de 2013 houve uma grande repressão policial e divergências de opiniões quanto ao momento ou não de suspender o aumento da tarifa, mas de fato essa mobilização da população indica a necessidade de se estudar e discutir melhor a forma como o serviço público é prestado, ainda que tal seja realizado por intermédio de empresas privadas.

Como serviço essencial, o aumento da tarifa impacta principalmente na vida dos usuários de baixa renda, que dependem do serviço público para suas atividades diárias e em geral habitam regiões mais afastadas do centro das cidades ${ }^{3}$.

O serviço de transporte é usualmente de competência dos municípios mas com a congregação deles em regiões nas quais muitas vezes não é possível definir onde uma cidade se inicia e outra termina devido à grande proximidade delas, surge a questão: a quem se deve incumbir a tarefa de circulação entre essas cidades?

Inicialmente se poderia pensar na criação de um ente administrativo que gerenciasse a relação entre esses municípios e fizesse a mediação entre os interesses de cada município integrante da região. Esta, porém, não foi a escolha política feita pelos constituintes para a problemática em questão. Como irá se estudar, as regiões metropolitanas não possuem personalidade jurídica, nem autonomia política. Apenas há a

\footnotetext{
${ }^{3}$ No caso da Região Metropolitana de São Paulo (e outras regiões também), as cidades ao redor se transformaram em sua periferia.
} 
subordinação ao ente estadual a que pertence, sem a independência financeira para seus investimentos.

Diante desse contexto, o que se pretende com este trabalho é analisar como funciona administrativamente as Regiões Metropolitanas, estudando inicialmente seu histórico e aprofundando tal estudo em relação à Região de São Paulo.

Com isso, surge a necessidade de entender o que é o serviço público e quais são as formas de sua delegação a terceiros (empresas privadas), bem como quais são as formas de remuneração do serviço prestado.

Após essa fase inicial, pretende-se estudar como é a delegação do serviço de transporte metropolitano em São Paulo, com a verificação de alguns elementos que compõe o sistema como os Operadores Regionais de Coletivos Autônomos, que surgiu diante da necessidade de legalizar o transporte realizado por vans e microônibus que se valiam da carência da população de um serviço de transporte melhor.

A partir dos dados antecedentes, buscar-se-á examinar o procedimento licitatório para a Área 1 da Região Metropolitana, bem como os contornos do atual edital para a Área 5, para entender como funciona a relação do Poder Público com as empresas privadas que prestam o serviço essencial do transporte para a população. Por fim, far-se-á uma análise crítica de todo o estudado. 


\section{BREVES NOTAS SOBRE DESENVOLVIMENTO SUSTENTÁVEL}

Antes de adentrar o tema das Regiões Metropolitanas, cabe fazer algumas notas sobre o que é desenvolvimento sustentável.

O tema do desenvolvimento sustentável foi inicialmente proposto internacionalmente como uma discussão a partir do documento intitulado Our Common Future, conhecido como Relatório Brundtland, publicado em 1987. Nesse relatório, apresenta-se como desenvolvimento sustentável o desenvolvimento que garanta o atendimento das necessidades do presente sem comprometer a capacidade das gerações futuras também atenderem as suas. No documento se afirma que a pobreza é a causa da degradação ambiental e para reverter isso é necessário empenho político

Conforme o professor Alberto do Amaral Júnior afirma ${ }^{4}$, o conceito de desenvolvimento sustentável permanece indeterminado, sendo cada usuário deste conceito faz a interpretação que convém. O referido professor, entretanto, aponta ser possível, ao seu ver, apontar os principais elementos que o constituem com base nos tratados internacionalmente acordados. Basicamente seu conceito de desenvolvimento sustentável inclui elementos substantivos e procedimentais. Os substantivos são a utilização sustentável dos recursos naturais, a integração entre a proteção do meio ambiente e o desenvolvimento econômico, o direito ao desenvolvimento e a busca de equidade na alocação dos recursos entre os membros da geração atual, bem como entre a geração presente e a geração futura, conforme os princípios 3 a 8 da Declaração do Rio de 1992. Os elementos procedimentais, por outro lado, tratam da participação pública nas decisões da avaliação de impacto ambiental e constam nos princípios 10 e 17 da referida Declaração ${ }^{5}$.

Há na atualidade a superação da perspectiva inicial totalmente unilateral que conceituava o desenvolvimento por sua característica meramente quantitativa. O princípio 4 da Declaração do Rio estabeleceu que a proteção do meio ambiente constitui uma parte integrante do processo de desenvolvimento e não pode ser considerado isolado disso.

\footnotetext{
${ }^{4}$ Comércio Internacional e a Proteção do Meio Ambiente, p. 60.

${ }^{5}$ Acerca da participação popular na tomada de decisões, especialmente aquelas relacionadas à proteção do meio ambiente, ver o artigo de Ângela Alonso e Valeriano Cost, Dinâmica Participação em Questões Ambientais: uma Análise das Audiências Públicas para o Licenciamento Ambiental do Rodoanel, In: Participação e Deliberação: Teoria Democrática e Experiências Institucionais no Brasil Contemporâneo, p. 290-312.
} 
Houve, assim, a integração de aspectos antes isolados, com ênfase na qualidade ambiental, que define o padrão comumente aceito para apreciar a legitimidade das políticas estatais. A forma como se pretende integrar o desenvolvimento com o meio ambiente ainda é incerta e controversa. O equilíbrio entre esses dois pólos, entretanto, é essencial para a evolução da humanidade.

O direito ao desenvolvimento, fundado em um consenso quase universal, adquiriu progressivamente caráter consuetudinário. Não é possível realizar uma análise segmentada dos aspectos do direito ao desenvolvimento, pois estes são indivisíveis e interdependentes. $\mathrm{O}$ direito ao desenvolvimento reforça outros direitos humanos anteriormente reconhecidos ao enfatizar os interesses dos indivíduos e coletividades ao mesmo tempo.

Tal visão do desenvolvimento, porém, tornou-se diferente com a experiência adquirida dos países desenvolvidos, após estes terem percorrido as várias etapas do crescimento econômico. Com etapas de crescimento concluídas, chegou-se a conclusão de que alguns meios pelos quais se utilizaram não seriam mais os melhores a se percorrer. Isso ocorre, entretanto, no momento em que outro países menos desenvolvidos se posicionam para buscar o tão esperado desenvolvimento. Esse novo conhecimento de causa propõe uma nova dificuldade àqueles que não tiveram mesmas condições iniciais para o crescimento. Desta forma, os países em desenvolvimento não possuem condição de abandonar por completo práticas reconhecidas agora como perigosas para o ambiente, como o uso de certos processos industriais e de combustíveis fósseis.

O desenvolvimento sustentável, numa de suas possíveis definições, encerra a ideia de evolução da diversidade humana, de equilíbrio dinâmico entre atividade econômica e a preservação dos sistemas ecológicos existentes. A noção, desta forma, explora a interdependência dos recursos naturais, a dependência humana desses recursos e os efeitos globais que a degradação do meio ambiente tem para a humanidade.

Tal ideia contém uma indisfarçável dimensão ética, conforme afirma o professor Alberto do Amaral Júnior ${ }^{6}$, manifestada no aperfeiçoamento de toda a sociedade ao longo do tempo. O desenvolvimento sustentável busca integrar a conservação e o desenvolvimento, satisfazer as necessidades humanas básicas, realizar a equidade e a

\footnotetext{
${ }^{6}$ Comércio Internacional e a Proteção do Meio Ambiente, p. 65.
} 
justiça social, promover a autodeterminação e a diversidade cultural, bem como manter a integridade ecológica.

A pobreza é vista hoje como um problema multidimensional e complexo que só poderá ser resolvido por programas que proponham solução para as múltiplas questões envolvidas e obtenham a participação da população. Desta forma, a integração entre o desenvolvimento e a proteção do meio ambiente é requisito para satisfazer as necessidades humanas essenciais e melhorar as condições de vida da humanidade, inclusive no meio urbano $^{7}$.

Com vistas a estas breves e prévias noções, segue-se ao estudo das Regiões Metropolitanas.

\footnotetext{
${ }^{7}$ Cabe citar, ainda que rapidamente, a contribuição de Nicolas Stern, em seu texto Executive Summary of the economics of climate change, em que evidencia que apesar de os países em desenvolvimento terem causado menores danos ao ambiente ao longo dos anos, ainda assim sofrerão as conseqüências das mudanças climáticas ocasionadas pelo próprio crescimento dos países desenvolvidos. A ação de todos países, ainda assim, deve ser movida pela cooperação a fim de que, independente da culpa específica de alguns, haja a possibilidade de continuidade de vida no planeta.
} 


\title{
3. REGIÃO METROPOLITANA
}

A partir dessa breve noção do que é desenvolvimento sustentável e sob esse prisma, deve-se estudar o que são as Regiões Metropolitanas.

Com o surgimento de núcleos urbanos decorrentes da crescente industrialização e atração por melhores condições de vida, trabalhadores deixaram o campo para se fixar em residências urbanas e buscar trabalho nas cidades. Isso, porém, ocorreu de forma desordenada, o que culminou com ocupações desregradas, e muitas vezes irregulares.

A crescente busca pela proximidade dos centros econômicos e produtivos a partir do desenvolvimento do modo de produção capitalista do século XX resultou na agregação de núcleos urbanos, que formaram grandes aglomerados, desrespeitando limites geográficos e as divisões político-administrativas reinantes. Esse fenômeno gerou conurbações $^{8}$ de diferentes dimensões, o que ocasionou as atuais Regiões Metropolitanas, ainda que tal fenômeno não seja essencial para a criação destas.

Eros Roberto Grau ${ }^{9}$ conceitua o que é região metropolitana da seguinte maneira:

\begin{abstract}
"[O] conjunto territorial intensamente urbanizado, com marcante densidade demográfica, que constitui um pólo de atividade econômica, apresentando uma estrutura própria definida por funções privadas e fluxos peculiares, formando, em razão disso, uma mesma comunidade socio-econômica em que as necessidades específicas somente podem ser, de modo satisfatório, atendidas através de funções governamentais coordenada e planejadamente exercitadas".
\end{abstract}

Complementa o professor que para o caso brasileiro, a região será o conjunto, com as características citadas, "implantado sobre uma porção territorial dentro da qual se distinguem várias jurisdições político-territoriais, contíguas e superpostas entre si Estados e Municípios”.

\footnotetext{
${ }^{8}$ Em relação à palavra conurbação, deve-se fazer uma pequena observação. Tal expressão foi criada, segundo Eros Roberto Grau (Regiões metropolitanas: regime jurídico. São Paulo: Bushatsky, 1974, p. 14) por Patrick Geddes, em 1915, em seu livro "Cities in evolution" e foi utilizada no contexto da Grande Londres e as regiões que a cercam, Manchester e Birmigham.

${ }^{9}$ Regiões metropolitanas: regime jurídico. São Paulo: Bushatsky, 1974, p. 25-26.
} 
Em sua concepção, então, na maioria das vezes, as regiões apresentam um município central, ao redor do qual gravitam os demais municípios circundantes, motivados pela intensidade econômica e social desenvolvida naquele polo de atração.

Segundo Alaor Caffé Alves, a realidade metropolitana se caracteriza não só por seu reconhecimento no mundo do direito, com a aceitação de alguns dos critérios oferecidos por outros campos do saber, mas também, e principalmente, pelo modo peculiar a que atende a abordagem normativa dos fatos. Isso quer dizer que o "ser" metropolitano nem sempre coincide plenamente com o "dever ser" metropolitano, podendo haver uma maior ou menor discrepância entre esses aspectos fundamentais da realidade e do mundo da cultura. $\mathrm{O}$ ideal é que haja uma convergência, de tal modo que o dever ser normativo reflita da melhor e mais autêntica forma possível a realidade do ser e dos valores metropolitanos. Ou melhor, que o dever ser metropolitano se contenha dentro das condições de possibilidade do ser metropolitano.

Roberto Rosas ${ }^{10}$ narra o aparecimento das regiões metropolitanas a partir dos fatos: afirma que o fenômeno da conurbação, observado pelos ingleses, de grandes formações urbanas complexas, congregando vários núcleos e cuja origem está entre duas ou mais unidades urbanas, serve ao Brasil. Assim, considerando a continuidade e contiguidade de ocupação de espaço físico, o deslocamento sistemático de parte considerável da população ativa, que se dirige da cidade para a metrópole, e a participação intermunicipal, verifica-se a existência de áreas que preenchem os requisitos básicos para se adotar uma série de medidas a sofrear os problemas múltiplos que sujam, porque os serviços decorreram da existência de problemas de dimensão metropolitana, cuja solução requer planejamento, coordenação e execução integrados, que o município isoladamente considerado não teria condições.

Hely Lopes Meirelles ${ }^{11}$ narra que a região metropolitana, como área de serviços unificados é adotada em vários países para melhor solução de problemas urbanos e interurbanos de grandes cidades como Paris, Los Angeles, São Francisco, Toronto, Londres e Nova Délhi. Nesses casos, entretanto, há uma delimitação da zona de influência da metrópole e é atribuído a uma única Administração o planejamento integral da área,

\footnotetext{
${ }^{10}$ Perspectiva Jurídica da Região Metropolitana. In. Revista de Direito Público. N. 28, Ano VII. São Paulo: RT, mar/abr de 1974.

${ }^{11}$ Meirelles, Hely Lopes. Direito Municipal Brasileiro. 14a ed. São Paulo: Malheiros, 2006, p.82-83.
} 
com a coordenação e promoção das obras e atividades de interesse comum da região para o atendimento das necessidades das populações interessadas.

Cabe ressaltar que, ainda que envolva necessariamente mais de um município, a instituição da região metropolitana não pode ferir a autonomia municipal, conforme verificaremos adiante.

Para dimensionar a importância do estudo, deve-se ressaltar que atualmente Quase metade da população brasileira (87,3 milhões de habitantes) mora em 8,6\% dos municípios do país, os quais integram as 48 regiões metropolitanas existentes hoje no Brasil $^{12}$.

Atualmente, o país conta com 37 regiões metropolitanas e três regiões integradas de desenvolvimento, totalizando 482 municípios e o Distrito Federal

\subsection{Histórico.}

O desenvolvimento de determinadas regiões no Brasil já era preocupação constitucional há tempos ao qual se buscava alguma solução através da cooperação entre os entes da federação. Nesse primeiro momento, entretanto, o foco não era especificamente o que hoje chamamos de regiões metropolitanas. Uma primeira preocupação dizia respeito a determinadas regiões brasileiras cujo desenvolvimento era considerado importante para o crescimento do país.

O primeiro exemplo que se pode extrair da História brasileira é o plano de aproveitamento das possibilidades econômicas do rio São Francisco, previsto no artigo 29 do Ato das Disposições Constitucionais Transitórias da Constituição Federal de $1946^{13}$. O que se destaca deste texto e dos demais que se seguiram é a posição da União Federal como elemento fundamental para a elaboração, implementação e execução do trabalho de desenvolvimento regional. Pode-se observar tal papel proeminente se tornou regra de

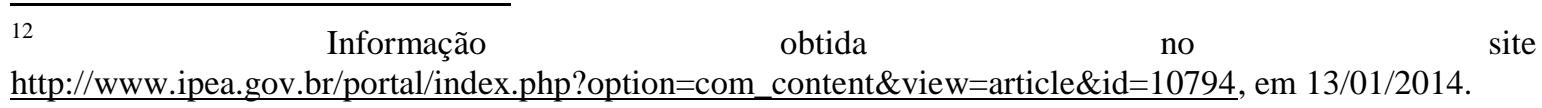

${ }^{13}$ Art 29 - O Governo federal fica obrigado, dentro do prazo de vinte anos, a contar da data da promulgação desta Constituição, a traçar e executar um plano de aproveitamento total das possibilidades econômicas do rio São Francisco e seus afluentes, no qual aplicará, anualmente, quantia não inferior a um por cento de suas rendas tributárias. 
competência prevista na Constituição Federal de 1967, também reproduzida na Emenda Constitucional $\mathrm{n}^{\mathrm{o}} 1$, de 1969, e foi vista como garantia permanente do exercício eficaz do federalismo cooperativo. Nesse sentido, houve a criação de diversos órgãos federais, como SUDENE, SUDAM, SUFRAMA, SUVALE, SUDECO, SUDESUL, para possibilitar o aceleramento do crescimento econômico em diversos estados brasileiros, com a realização de grandes investimentos.

A ideia de região metropolitana, entretanto, não decorreu dessa preocupação inicial de suprir o subdesenvolvimento do país para gerar o tão almejado crescimento econômico. Ao contrário, a própria palavra metropolitano está conceituado no dicionário Houaiss como "relativo a, próprio de, que tem aspecto de metrópole ('capital', 'cidade grande')"14. Deve-se notar que o próprio dicionário consultado faz referência à expressão "cidade grande", termo que nos remete à própria História brasileira. Pode-se dizer, assim, que essas regiões são "fruto do desenvolvimento, da industrialização e da explosão demográfica" ${ }^{\prime 15}$.

\subsubsection{As Constituições de 1937, 1946 e 1967 e a Emenda Constitucional 1/1969.}

O primeiro texto constitucional a prever algo próximo ao que hoje se denomina região metropolitana foi aquele de 1937, no qual se concebeu, em seu artigo 29, que municípios de uma mesma região poderiam agrupar-se para a instalação, exploração e administração de serviços públicos comuns e, para tanto, o agrupamento constituído seria dotado de personalidade jurídica limitada a seus fins. É importante notar, entretanto, que o parágrafo único do referido artigo prevê que a competência para regular as condições nas quais tais agrupamentos seriam constituídos, bem como a forma de suas administrações, seria dos Estados. Poder-se-ia se alongar neste tema, refletindo qual a importância dessa escolha do constituinte, seus possíveis reflexos na economia e na política, porém como tal competência não se exerceu, não houve reflexos práticos para estudo.

\footnotetext{
${ }^{14}$ Dicionário Eletrônico Houaiss, disponível pelo site www.uol.com.br a assinantes.

15 Horta, Raul Machado, Regiões Metropolitanas e Direito Constitucional, in Clève, Clèmerson Merlin; Barroso, Luís Roberto (org.), Direito Constitucional: organização do Estado, p. 634.
} 
A Constituição de 1946 foi silente em relação à possibilidade de agrupamento de municípios com o intuito de possibilitar e organizar seu desenvolvimento, como prevista em disposição constitucional precedente.

Essa inovação prevista na Carta de 1937, contudo, trouxe a inspiração para a Comissão de Juristas instituída pelo Presidente Castelo Branco em 1966, incumbida de reformular a Constituição Federal de então ${ }^{16}$. No anteprojeto apresentado pela Comissão, há a previsão de dois artigos importantes para a concepção de região metropolitana que são os artigos 246 e 247, redigidos na seção intitulada "Dos Municípios":

\begin{abstract}
“Art. 246 - A União ou o Estado poderá estabelecer temporariamente, por lei, com a concordância das câmaras de vereadores e assembleias legislativas, áreas de desenvolvimento prioritário, nas quais realizará as obrigações e serviços necessários ao reerguimento sócio-econômico conveniente da região. Realizadas as obras, e os serviços programados, voltarão as áreas à administração do município a que pertencerem.

Art. 247 - Os Estados poderão, mediante autorização de 2/3 dos membros de suas assembléias legislativas, e das respectivas câmaras de vereadores, estabelecer administração conjunta de alguns municípios, visando à realização de obras ou serviços públicos, ou a outros objetivos de interesse comum."
\end{abstract}

O primeiro artigo, como bem aparenta, está em consonância com a política inicialmente destacada de desenvolvimento regional e não necessariamente ligada à ideia de regiões metropolitanas, ainda que tal dispositivo pudesse ser usado para o auxílio de determinadas cidades de alta concentração demográfica e algum desenvolvimento industrial. É claro, entretanto, o caráter temporário do disposto no artigo, já que ao fím do objetivo almejado, as áreas especificas para desenvolvimento voltariam à administração do ente local. O segundo artigo, por outro lado, possui uma configuração mais próxima de região metropolitana, prevendo a realização de objetivos comuns entre entes - Estado e municípios - em caráter continuado, sem a ideia do outro instituto de temporariedade. Em ambos os casos, porém, há a previsão de um ritual próprio com formalidades que prejudicariam sua aplicação prática. Essas disposições do Anteprojeto, entretanto, não foram positivadas. No projeto apresentado pelo Presidente Castelo Branco não havia a previsão expressa dessas melhorias.

Referências à região metropolitana foram somente incluídas sob a forma de emenda por iniciativa de membros do Congresso Nacional. A emenda de $\mathrm{n}^{\circ} 848$, conhecida

${ }^{16}$ Horta, Raul Machado, Regiões Metropolitanas e Direito Constitucional, in Clève, Clèmerson Merlin; Barroso, Luís Roberto (org.), Direito Constitucional: organização do Estado, p. 635/636. 
também como Emenda Eurico Rezende, autorizava a União, através de lei complementar, a estabelecer regiões metropolitanas, que seriam constituídas por municípios que, independentemente de sua vinculação administrativa, integrem a mesma comunidade socioeconômica para a realização de interesses comuns ${ }^{17}$. Nesse contexto, deve-se destacar a justificação publicada em conjunto com a emenda:

\begin{abstract}
As regiões metropolitanas constituem hoje em dia uma realidade urbanística que não pode ser desconhecida das administrações modernas, nem omitidas no planejamento regional. Por regiões metropolitanas, entendem-se aquêles Municípios que gravitam em tôrno da grande cidade, formando com esta uma unidade sócio-econômica, com serviços urbanos e interurbanos. Assim sendo, tais serviços deixam de ser de exclusivo interêsse local, por vinculados estarem a tôda a comunidade metropolitana. Passam a constituir a tessitura intermunicipal daquelas localidades, e, por isso mesmo, devem ser planejados e executados em conjunto por uma administração unificada e autônoma, mantida por todos os Municípios da região, na proporção de seus recursos, e se éstes forem insuficientes, hão de ser complementados pelo Estado e até mesmo pela União, porque os seus benefícios também se estendem aos governos estadual e federal. Eis por que a emenda propõe o reconhecimento constitucional dessa realidade, possibilitando a unificação dos serviços intermunicipais de regiões metropolitanas, subvenção estadual e federal se necessário, para o pleno atendimento da imensa população que se concentra nessas regiões. Nações civilizadas já adotaram essa técnica administrativa, com excelentes resultados, como é o caso de Toronto, Londres e Nova Delhi.
\end{abstract}

Como se pode observar, há nessa justificativa o reconhecimento da realidade existente e a preocupação em se tutelar tal realidade metropolitana com contornos de constitucionalidade. Abrigar os eventos que ocorrem no mundo do ser, auxilia, assim, o desenvolvimento da ideia do que deverá ser, projetando objetivos precisos para o aprimoramento do país. A partir desta justificativa, Roberto Rosas ${ }^{18}$ enfatiza que pretendiase, com isso, reconhecer como região metropolitana a unidade que constitui a comunidade socioeconômica, independente da vinculação administrativa.

A referida emenda foi integrada no projeto final da Constituição de 1967, sendo reproduzida integralmente em seu artigo 157, parágrafo 10, do Título III - Da Ordem Econômica e Social.

\footnotetext{
${ }^{17}$ Esta Emenda comandava ao aditamento do art. 157 o parágrafo $9^{\circ}$ que teria o conteúdo narrado. A referida emenda foi publicada no Diário do Congresso Nacional, Suplemento ${ }^{\circ} 1$, de 06/01/1967, p. 129, e pode ser visualizada no site: http://imagem.camara.gov.br/dc_20b.asp?largura=\&altura=\&selCodColecaoCsv=D\&Datain=06\%2F01\%2F1 967\&txPagina $=\&$ txSuplemento $=1$

${ }^{18}$ Perspectiva Jurídica da Região Metropolitana. In. Revista de Direito Público. N. 28, Ano VII. São Paulo: RT, mar/abr de 1974, p. 87.
} 
Com as mudanças políticas da época, sobreveio a Emenda Constitucional $\mathrm{n}^{\circ} 1$, de 17/10/1969, que alterou substancialmente a Constituição de então. Em relação às regiões metropolitanas, porém, o texto manteve a posição das mesmas, com algumas alterações de cunho meramente formal, e tornou-as objeto de dispositivo próprio, o artigo 164, o qual dispõe o seguinte:

Art. 164. A União, mediante lei complementar, poderá para a realização de serviços comuns, estabelecer regiões metropolitanas, constituídas por municípios que, independentemente de sua vinculação administrativa, façam parte da mesma comunidade sócio-econômica.

Deve-se destacar o viés centralizador presentes tanto na Carta de 1967, tanto na Emenda Constitucional $n^{\circ} 1$ analisada, já que se define que a instituição das regiões seria realizada pela União, sem disposição acerca da participação dos estados-membros ou municípios envolvidos. Esta centralização pode ser associada a uma tentativa da União intervir nos polos urbanos de grande relevância econômica, de forma a direcionar seu crescimento da forma que lhe conviesse, lembrando que no período estudado o país era governado pelos militares.

Neste ponto, cabe ressaltar os apontamentos de Edésio Fernandes ${ }^{19}$ de que "a titularidade do interesse metropolitano foi atribuída, ainda que de maneira pouco elaborada, a associações compulsórias de municípios", revelando que não haveria qualquer menção à competência dos estados-membros em matérias metropolitanas, o que diverge da atual situação, como se verá adiante. Este cenário causa de certa forma estranheza, já que a União, que é maior que os estados e tem interesses mais amplos, interviria diretamente em municípios, deixando o questionamento de qual o papel dos estados diante dessa intromissão.

Há ainda a restrição do campo de atuação das regiões apenas para a realização de serviços de interesse comum. A respeito das limitações estabelecidas pelo constituinte, Raul Machado Horta frisa que:

${ }^{19}$ O Elo Perdido: o Desafio da Gestão Metropolitana. In: Alfonsin, Betânia de Moraes; Fernandes, Edésio. Direito Urbanístico - Estudos Brasileiros e Internacionais. Belo Horizonte: Del Rey, Lincoln Institute of Land Policy, 2006, p. 364. 
"[A] região metropolitana há de ser executora de serviços comuns, não podendo converter-se sob a estrutura constitucional vigente, em entidade de governo ou em circunscrição político-administrativa, pois a Constituição, na sua normatividade suprema, desconhece uma e outra. Daí a complexa tarefa que se deixou ao legislador ordinário, responsável pelo estabelecimento de regiões metropolitanas, dentro de parâmetros constitucionais rigorosos, dos quais não pode fugir, por mais sedutoras que sejam as soluções contidas em modelos estrangeiros, os quais gostaria certamente de transplantar." 20

Alaôr Caffé Alves ${ }^{21}$ destaca, analisando o dispositivo constitucional, em vista de toda a sistemática jurídico-constitucional, que o objetivo da entidade metropolitana a ser criada não se limitaria apenas ao planejamento, controle e coordenação dos serviços comuns de caráter metropolitano, podendo, inclusive executá-los diretamente. Ressalte-se que, diante de todos esses poderes, o controle da União sobre as regiões metropolitanas seria superior ao necessário, com intervenção direta nos municípios, direcionando-os a realizar o que lhe convém.

\subsubsection{A Lei Complementar no $14 / 1973$}

Da promulgação da Constituição Federal de 1967 até a publicação da Lei Complementar $\mathrm{n}^{\circ} 14$, de 8/6/1973, houve intensa discussão acerca de como a Lei Complementar deveria dispor sobre as regiões metropolitanas: para uns seria necessário a aprovação de leis específicas para cada região a ser criada, para outros seria preciso somente a aprovação de lei complementar que disporia sobre normas gerais das regiões metropolitanas e que estas seriam criadas com decretos. Outras questões foram levantadas por teóricos e políticos, principalmente em relação à autonomia dos municípios.

Ao final, foi aprovada a Lei Complementar $n^{\circ} 14$, que de certa forma harmonizou os entendimentos antes referidos. De acordo com o pensamento de Edésio

${ }^{20}$ Horta, Raul Machado, Regiões Metropolitanas e Direito Constitucional, in Clève, Clèmerson Merlin; Barroso, Luís Roberto (org.), Direito Constitucional: organização do Estado, p. 638.

${ }^{21}$ A Competência Municipal e o Planejamento Metropolitano - notas sobre a possiblidade jurídica do entrosamento compulsório entre o Estado e os Municípios da Grande São Paulo para o planejamento metropolitano, in Clève, Clèmerson Merlin; Barroso, Luís Roberto (org.), Direito Constitucional: organização do Estado, vol. III, São Paulo, Revista dos Tribunais, 2011, p. 800. 
Fernandes $^{22}$, a natureza atribuída às regiões metropolitanas, a partir dessa norma, foi um híbrido de regiões de serviços comuns, região de planejamento territorial e região de desenvolvimento econômico. A citada norma criou oito regiões metropolitanas: São Paulo, Belo Horizonte, Porto Alegre, Recife, Belém, Fortaleza, Curitiba e Salvador ${ }^{23}$. Ao mesmo tempo, houve a especificação de normas gerais de organização das regiões metropolitanas $^{24}$.

A referida lei previu dois órgãos colegiados para a região metropolitana: o Conselho Deliberativo e o Conselho Consultivo, ambos criados por lei estadual. O primeiro era composto por cinco membros de reconhecida capacidade técnica ou administrativa, nomeados pelo Governador do Estado. Dentre esses cinco, um deles seria escolhido dentre os nomes que figurem em lista tríplice organizada pelo prefeito da capital e outro mediante indicação dos demais municípios integrantes da região metropolitana, conforme expressamente deduzido no parágrafo $1^{\mathrm{a}}$ do artigo $2^{\mathrm{o}}$ da Lei. O Conselho Consultivo, por outro lado, seria composto de um representante de cada município integrante da região metropolitana sob a direção do presidente do Conselho Deliberativo (parágrafo $2^{\circ}$ do artigo $2^{\circ}$ da Lei).

O que se observa desse contexto é que a lei complementar deu proeminência ao Estado, que está no comando do planejamento e da execução dos serviços de interesse metropolitano, não somente pela competência do Estado para criar os órgãos, como bem ressalta Toshio Mukai ${ }^{25}$, mas porque o principal órgão, o Conselho Deliberativo, seria composto de três membros do governo estadual, dentre os cinco elementos de sua constituição. É imperioso destacar a posição de José Afonso da Silva ${ }^{26}$, que afirma que a

${ }^{22}$ O Elo Perdido: o Desafio da Gestão Metropolitana. In: Alfonsin, Betânia de Moraes; Fernandes, Edésio. Direito Urbanístico - Estudos Brasileiros e Internacionais. Belo Horizonte: Del Rey, Lincoln Institute of Land Policy, 2006, p. 364.

${ }^{23}$ Além dessas, a Lei Complementar no 20/1974 acrescentou a região metropolitana do Rio de Janeiro.

${ }^{24}$ Esta é a posição defendida pelo Raul Machado Horta (Regiões Metropolitanas e Direito Constitucional, in Clève, Clèmerson Merlin; Barroso, Luís Roberto (org.), Direito Constitucional: organização do Estado, p. 640). Outra é a posição de Toshio Mukai (O Regime Jurídico Municipal e as Regiões Metropolitanas (conforme Emenda Constitucional n. ${ }^{\circ} 1 / 69$ ), $1^{a}$ ed., São Paulo: Sugestões Literarias, 1976, p. 99), que defende que as a Lei 14/73 não é norma geral e que só deve ser aplicada às regiões que criou. $\mathrm{O}$ autor baseiase na interpretação que faz do artigo 164 da Constituição de então na qual não haveria autorização para a União impor normas gerais sobre as regiões metropolitanas, tal autorização, se houvesse, deveria ser expressa.

${ }^{25}$ O Regime Jurídico Municipal e as Regiões Metropolitanas (conforme Emenda Constitucional n. ${ }^{\circ} 1 / 69$ ), $1^{\text {a }}$ ed., São Paulo: Sugestões Literárias, 1976, p. 102.

${ }^{26}$ Direito Urbanístico Brasileiro, 6a ed. São Paulo, Malheiros, 2010, p. 152. 
União instituiu as regiões metropolitanas, "mas não tomou mais, praticamente, conhecimento delas". Nesse sentido, conclui que os Estados ficaram responsáveis pela estruturação das regiões e seu funcionamento, criando empresas ou autarquias para darlhes efetividade.

Ao Conselho Consultivo competiria apenas opinar e sugerir, por solicitação do Conselho Deliberativo. Este, por sua vez, seria a entidade metropolitana de maior peso, que promoveria o Plano de Desenvolvimento Integrado da Região Metropolitana e a programação dos serviços comuns, com competência, ainda, para coordenar a execução dos serviços e, sempre que possível a unificação dos serviços comuns metropolitanos. A respeito dessa unificação, ela seria realizada por concessão de serviço a entidade estadual ou pela constituição de empresa de âmbito metropolitano, ou ainda por processos que, através de convênio, fossem estabelecidos ${ }^{27}$.

Um destaque especial deve ser feito ao artigo $5^{\circ}$ da Lei Complementar, que define quais os serviços comuns que se reputam de interesse metropolitano ${ }^{28}$. Nesse sentido haveria uma dúvida quanto à extensão desses serviços, já que poderia ferir o princípio da autonomia municipal. Dessa forma, para não ferir tal princípio, no entendimento de Toshio Mukai ${ }^{29}$, dever-se-ia interpretar que não são todas as parcelas de serviços de interesses comuns que poderiam ser geridas a nível metropolitano. Assim, a unificação dos serviços não deveria importar em restrições à livre gestão dos serviços locais e é nesse sentido que se deveria entender a expressão da lei "quando possível". Apesar da necessidade da autonomia municipal, deve-se frisar que para o estabelecimento

\footnotetext{
${ }^{27}$ Segundo Toshio Mukai (O Regime Jurídico Municipal e as Regiões Metropolitanas (conforme Emenda Constitucional n. $\left.{ }^{\circ} 1 / 69\right), 1^{a}$ ed., São Paulo: Sugestões Literárias, 1976, p. 103), uma vez que as formas de unificação dos serviços foram expressamente previstas na lei complementar, "nenhuma outra alternativa poderá ser objeto de manipulação para a unificação dos serviços, senão através de convênios". Em sentido contrário, Raul Machado Horta (Regiões Metropolitanas e Direito Constitucional, in Clève, Clèmerson Merlin; Barroso, Luís Roberto (org.), Direito Constitucional: organização do Estado, p. 641) entende que a relação disposta no artigo $5^{\circ}$ é não exaustiva. Os serviços dispostos no referido artigo são: I - planejamento integrado do desenvolvimento econômico e social; II - saneamento básico, notadamente abastecimento de água e rede de esgotos e serviço de limpeza pública; III - uso do solo metropolitano; IV - transportes e sistema viário; V - produção e distribuição de gás combustível canalizado; VI - aproveitamento dos recursos hídricos e controle da poluição ambiental, na forma que dispuser a lei federal; VII - outros serviços incluídos na área de competência do Conselho Deliberativo por lei federal.

${ }^{28}$ Para Toshio Mukai (O Regime Jurídico Municipal e as Regiões Metropolitanas (conforme Emenda Constitucional n. ${ }^{\circ}$ 1/69), $1^{\text {a }}$ ed., São Paulo: Sugestões Literárias, 1976, p. 104), as hipóteses que a lei previu eram taxativas, de forma que seria necessária nova Lei Complementar para instituir outros serviços comuns de interesse metropolitano.

${ }^{29}$ O Regime Jurídico Municipal e as Regiões Metropolitanas (conforme Emenda Constitucional n. ${ }^{\text { }}$ 1/69), $1^{\text {a }}$ ed., São Paulo: Sugestões Literárias, 1976, p. 104.
} 
desses serviços de interesses comuns é necessário o comprometimento dos municípios envolvidos para que não tentem competir com esses serviços de nível metropolitano, nem que estes interfiram no serviço municipal.

Ainda, sobre a unificação dos serviços de interesse comum, cabe ressaltar que a lei ofereceu solução diversificada para tanto. Autoriza a lei a concessão do serviço a entidade estadual, constituição de empresa de âmbito metropolitano ou processos estabelecidos mediante convênio, conforme artigo $3^{\circ}$, parágrafo único. Deve-se observar, entretanto, que não houve atribuição de receita autônoma à região metropolitana. Houve, porém, a disposição no artigo $6^{\circ}$, caput, de que aqueles municípios que participassem da execução do planejamento integrado e dos serviços comuns teriam preferência na obtenção de recursos federais e estaduais, inclusive sob a forma de financiamentos e garantias para empréstimos.

Assim, a Lei Complementar n ${ }^{\circ}$ 14/1973 praticamente exauriu no seu conteúdo a matéria legislativa aplicável ao novo instrumento da administração supramunicipal, uma vez que houve a organização das regiões metropolitanas, bem como o estabelecimento de algumas delas. Nesse contexto, houve a previsão de que o legislador estadual deveria estabelecer leis para o fim específico de criação do Conselho Consultivo e Conselho Deliberativo, já que suas funções já estavam previstas na Lei federal. Por fim, destaca-se que não há autonomia metropolitana dotada de quadro de competência constitucional. A base constitutiva da região metropolitana está na pluralidade de municípios e a finalidade constitucional de sua criação está nos serviços comuns, que não devem ser locais, já que estes pertencem aos municípios, por norma constitucional imperativa, dentro de sua autonomia administrativa.

Por fim, deve-se acrescentar a crítica formulada por José Afonso da Silva ${ }^{30}$ à Lei Complementar $n^{\circ}$ 14/1973. Segundo o renomado professor, a referida Lei teria deformado seu sentido, com a atribuição indevida de encargos e competências aos Estadosmembros. Isso gerou um sistema de organização administrativa metropolitana ineficaz, culminando com a criação de entidades paralelas incompreensíveis à luz do dispositivo constitucional então vigente. A isso se seguiu resistências e conflitos que emperraram a viabilidade da instituição.

${ }^{30}$ Direito Urbanístico Brasileiro, 6 ${ }^{a}$ ed. São Paulo, Malheiros, 2010, p. 158-159. 
Em que se pese a crítica acima, houve uma evolução na atribuição de competência aos estados, que estariam mais próximos da realidade dos municípios integrantes das regiões metropolitanas. A organização administrativa instaurada a partir da Lei, porém, é em demasia complexa e pouco prática para a realidade. A composição de órgãos com indicações dos municípios integrantes das regiões é outra evolução importante, já que esses entes podem trazer ao debate das necessidades regionais suas questões locais. Não há que se dissociar a região das cidades dela integrantes, sob pena de criar níveis de serviços que não se comunicam e, desta forma, são pouco aproveitados pela população local.

\subsubsection{A Constituição de 1988}

O conceito de Região Metropolitana atual não está disposto apenas na doutrina, está consagrado também no artigo 25, parágrafo terceiro da Constituição Federal de 1988, que dispõe o seguinte:

$\S 3^{\circ}$ - Os Estados poderão, mediante lei complementar, instituir regiões metropolitanas, aglomerações urbanas e microrregiões, constituídas por agrupamentos de municípios limítrofes, para integrar a organização, o planejamento e a execução de funções públicas de interesse comum.

A preocupação do constituinte em tutelar a realidade brasileira reflete um tratamento mais estrutural a respeito das regiões metropolitanas, com previsão constitucional. Ao contrário da Constituição anterior, que tratava da matéria metropolitana como disposição da Ordem Econômica, a atual Constituição deslocou o tratamento para o título referente à Organização do Estado. Segundo Alaôr Caffé Alves, esse deslocamento configura de forma evidente o objetivo do constituinte em tratar a questão como de interesse estrutural e organizativo do próprio Estado brasileiro, e não como manifestação de interesse meramente econômico.

De acordo com o texto normativo, pode-se extrair que a multiplicidade de entes governamentais de nível local é condição necessária para a configuração jurídica das regiões metropolitanas, condição esta não necessariamente imposta para a configuração 
dessas regiões em seus conceitos econômicos e urbanísticos ${ }^{31}$. A questão metropolitana se afigura dentro da necessidade de integrar funções públicas de interesse comum de todos os entres autônomos existentes, municípios e Estado.

Não há que se falar, entretanto, que as regiões metropolitanas configurem novas pessoas políticas. Como se sabe, a Constituição adota a Federação como sistema político e é assim que distribui geograficamente as competências internas e o exercício do poder político. União, Estados-membros, Municípios e Distrito Federal são as únicas pessoas qualificadas constitucionalmente como políticas. Desta forma, esses entes são pessoas jurídicas governamentais dotadas do poder de legislar, de ter um Parlamento próprio, com a consequente criação de normas em sua esfera de competência.

Assim, essas pessoas políticas possuem a competência de se organizar, editando uma Constituição ou Lei Orgânica que os assentem como pessoas exercentes do poder político. Temos assim que as Regiões Metropolitanas não podem ser tidas como pessoas políticas, não constituindo uma esfera própria de exercício de competências no todo da federação.

Observa-se claramente, pelo dispositivo em questão, que integra o capítulo constitucional referente aos Estados federados, que a competência da Região Metropolitana insere-se no interior da competência dos Estados-membros da Federação. São instituídas por lei estadual e reguladas pela legislação estadual. Não são, portanto, instancias políticas da Federação, mas, sim, instâncias administrativas estaduais, podendo ser instituídas com caráter autárquico ou como integrante da Administração Direta. O regime de direito público lhes é inerente, pela natureza dos atos que compõe seu regime constitucional, os quais, ao menos em parte de seu conjunto, devem ser praticados no exercício de prerrogativas de autoridade.

Isso, entretanto, não significa uma melhora no tratamento do tema, já que nos últimos trinta $\operatorname{anos}^{32}$ não houve um padrão de investimentos em obras metropolitanas, o

\footnotetext{
${ }^{31}$ Nesse sentido, Alaôr Caffé Alves, Regiões Metropolitanas, Aglomerações Urbanas e Microrregiões: Novas Dimensões Constitucionais da Organização do Estado Brasileiro. In: Bittar, Eduardo C. B. (org.), História do Direito Brasileiro: Leituras da Ordem Jurídica Nacional. São Paulo: Atlas, 2003, p. 350.

${ }^{32}$ A década com maior investimento, até a presente data, é ainda a década de 1970, na qual foram, inclusive, criados os metrôs de São Paulo e do Rio de Janeiro. Deve-se lembrar, porém, que nesta época ainda se tinha o Governo Militar, totalmente antidemocrático, com a centralização das questões metropolitanas para a União. A década de 1980 foi praticamente nula em termos de investimentos, já que houve a famosa crise
} 
que demonstra uma falta de integração entre as ações de cada município que compõe as metrópoles. Tudo isso reflete também que os estados apresentam ainda planos metropolitanos setoriais, que são raramente implementados ${ }^{33}$.

A mera imposição de um modelo sem o efetivo comprometimento com o tema prejudica a verdadeira existência de regiões metropolitanas comprometidas com o bem comum e desenvolvimento regional. $\mathrm{O}$ que aparenta faltar às regiões metropolitanas no pós-democracia é a efetiva participação da população afeta às regiões em conjunto com as administrações locais e regional para a proposição de soluções de competência conjunta. Há de fato municípios com rendas superiores a outros que não se comprometem a auxiliar mais que outros. Ao que parece não há muita cooperação entre as administrações e falta, de fato, fontes de investimento metropolitano que sejam mais constantes e consistentes.

\subsection{Região Metropolitana de São Paulo}

A Região Metropolitana de São Paulo é atualmente constituída por 39 municípios, que representam 3,4\% do total do território do Estado, com uma área de 8.051 $\mathrm{km} 2$, concentrando $48,04 \%$ da população estadual. A região é considerada o maior pólo de riqueza nacional. O seu Produto Interno Bruto (PIB) atingiu em 2008 R 572 bilhões $^{34}$, o que corresponde a cerca de $57 \%$ do total do Estado.

\subsubsection{Histórico.}

A Região Metropolitana de São Paulo foi, em algumas ocasiões, um ponto estratégico para a interligação das regiões brasileiras Sudeste e Centro-Oeste. Durante o

fiscal. Ainda após a Constituição de 1988, entretanto, não houve grande melhora nos investimentos metropolitanos.

${ }^{33}$ Acerca do tema, Erminia Maricato (Metrópoles desgovernadas, Estudos Avançados, vol. 25, n. 71, jan/abr de 2011) afirma que não raro a organização urbanística de um município pertencente a uma região metropolitana prejudica os demais. Ela destaca também que temas como o transporte de passageiros são temas que exigem um tratamento integrado na metrópole, mas que não há integração administrativa e que ao que pensa não há interesse no assunto, estando a questão metropolitana num "limbo".

${ }^{34}$ Dados verificados no site: http://www.sdmetropolitano.sp.gov.br/portalsdm/sao-paulo.jsp, acessado em $11 / 01 / 2014$ 
período de colonização brasileira, a proximidade dos rios Tietê, Pinheiros e Tamanduateí, que corriam para o interior, propiciaram a formação de vilas, uma vez que esses rios eram usados como meios de circulação durante o período colonial.

No auge da produção do café e da grande expansão da cidade de São Paulo, houve a construção da Estrada de Ferro São Paulo Railway Company, que ligava o porto de Santos a Jundiaí, e as estradas de ferro Paulista, Sorocabana e Central do Brasil. Isso tudo ocorreu devido ao papel importante da cidade, que continuou a fazer as ligações entre o porto de Santos e o interior de São Paulo e do Brasil, como já ocorria no período colonial. É essa mesma infraestrutura viária que resultou nos atuais sistemas rodoviários que desembocam na capital e ligam as três regiões metropolitanas paulistas: Santos, São Paulo e Campinas.

\subsubsection{Decreto estadual $n^{\circ} 47.863 / 67$}

A primeira referência legislativa à Região Metropolitana de São Paulo, que há muito já se verificava no plano fático, está no Decreto no 47.863 , de 29/03/1967, expedida pelo Governo do Estado. À época, denominava-se a região como “Grande São Paulo”. Este texto foi criado durante a vigência da Constituição Federal de 1967, que dispunha da competência da União Federal em estabelecer regiões metropolitanas ${ }^{3536}$, o que foi ignorado pelo Governo Estadual.

O importante de se notar, entretanto, são as razões pelas quais foi o decreto criado. O governador de então, Roberto Costa de Abreu Sodré, enumerou oito motivações para o decreto que são importantes para compreender o contexto em que tal ato foi editado. A primeira enfatiza a importância da região para o país, "não apenas pelo porte da sua população e pela importância das funções econômicas, administrativas e sociais que

\footnotetext{
${ }^{35}$ Artigo 156, parágrafo $10^{\circ}$, da Constituição Federal de 1967.

${ }^{36}$ Ainda que a competência expressa fosse da União, houve a edição do decreto que cumpriria os desígnios dos Estados de administrarem os seus territórios. Nesse sentido é também o pensamento de Daniela Cordeiro de Farias Munhoz (Regiões Metropolitanas. In. Dallari, Adilson Abreu; Di Sarno, Daniela Campos Libório. Direito Urbanístico e Ambiental. Belo Horizonte: Fórum, 2011, p. 192), que destaca ainda que a administração dos estados em relação aos seus territórios seria "nos termos de suas características peculiares".
} 
concentrou, como também por constituir um polo de desenvolvimento fundamental ao progresso do país".

O destaque que se fez foi a necessidade de um planejamento do crescimento da região, para melhorar as "deseconomias" que comprometiam o desenvolvimento. Há um reconhecimento de que grande parte da população do Estado se concentrava na região e que esta possuía uma deficiência nos serviços prestados, principalmente aqueles que envolviam saúde, educação, transportes e abastecimento. Assim, verificou-se que a solução seria integrar e harmonizar as soluções parciais aventadas individualmente pelos diferentes órgãos públicos, com a compatibilização de programas e prioridades dentro de um plano do conjunto.

Uma vez que o Estado era responsável por parcela fundamental de serviços públicos e que disporia de um importante acervo de conhecimentos, análises, planos e projetos, declarou-se o Governo habilitado a elaborar um plano para a conhecida Grande São Paulo. A justificativa jurídica seria de que o Estado, melhorando os serviços públicos dos quais seria responsável, atenderia ao dispositivo constitucional que valoriza o planejamento de Áreas Metropolitanas. Haveria uma consonância de tal prática com iniciativas já tomadas pelos municípios da região, bem como do interesse das agências de financiamento nacionais e internacionais por programas desse porte.

A partir do decreto, procurou-se definir estruturas administrativas para o processo contínuo de planejamento da área metropolitana. A preocupação era assegurar níveis técnicos elevados, harmonizar centros de decisão das esferas federal, estadual e municipal e compatibilizar objetivos de curto e longo prazos, com a previsão de alguma participação de segmentos verticais e horizontais da população.

No referido texto normativo ${ }^{37}$ há uma exposição clara de quais seriam os municípios que compunham a região, numa delimitação preliminar: Barueri, Brás, Caieiras, Carapicuíba, Cajamar, Cotia, Diadema, Embu, Embu Guaçu, Ferraz de Vasconcelos, Francisco Morato, Franco da Rocha, Guarulhos, Itapecirica da Serra, Itapevi, Itaquaquecetuba, Jandira, Mairiporã, Mauá, Moji das Cruzes, Osasco, Poá, Pirapora do Bom Jesus, Rio Grande da Serra, Ribeirão Pires, Santana do Parnaíba, Santo André, São Bernardo do Campo, São Caetano do Sul, São Paulo, Suzano, Taboão da Serra.

${ }^{37}$ Artigo $1^{\mathrm{a}}$, parágrafo $1^{\mathrm{o}}$, do Decreto $\mathrm{n}^{\mathrm{o}} 47.863 / 67$. 
O decreto criou o Conselho de Desenvolvimento da Grande São Paulo, órgão de caráter consultivo, presidido pelo Governador do Estado. Somado a este, mais alguns representantes do governo do Estado, da prefeitura da Capital e dos municípios metropolitanos. Os membros mais interessantes de se destacar são os representantes da Universidade de São Paulo, e de institutos ligados a classes - arquitetos e engenheiros - e um representante da Sociedade Amigos da Cidade, que conferiria alguma participação popular ao planejamento metropolitano.

No mesmo texto normativo foi criado o Grupo Executivo da Grande São Paulo (GEGRAN), subordinado ao governador do Estado, ao qual competiria, em síntese, promover a elaboração e aprovar o Plano Estadual da Grande São Paulo, o qual deveria integrar e complementar os programas e projetos de importância para a área nos órgãos da administração estadual levando em conta também aqueles adotados pelas autoridades municipais e federais.

\subsubsection{Lei Complementar Estadual n 94/74}

Em consonância com a Lei Complementar $n^{\circ} 14 / 73$, na qual a União instituiu oito regiões metropolitanas, dentre as quais a de São Paulo, a Lei Complementar Estadual $\mathrm{n}^{\circ}$ 94, de 29 de maio de 1974, foi editada. Neste contexto, foi autorizada a instituição do Fundo Metropolitano de Financiamento e Investimento - FUMEFI.

No artigo $1^{\circ}$ do referido diploma legal basicamente se repetiu a constituição da Região Metropolitana de São Paulo, já prevista no artigo $1^{\circ}$, parágrafo $1^{\circ}$, da Lei Complementar $n^{\circ} 14 / 73$, que dispõe que a área territorial metropolitana teria a abrangência dos seguintes municípios: São Paulo, Arujá, Barueri, Biritiba-Mirim, Caieiras, Cajamar, Carapicuíba, Cotia, Diadema, Embu, Embu-Guaçu, Ferraz de Vasconcelos, Francisco Morato, Franco da Rocha, Guararema, Guarulhos, Itapecerica da Serra, Itapevi, Itaquaquecetuba, Jandira, Juquitiba, Mairiporã, Mauá, Mogi das Cruzes, Osasco, Pirapora do Bom Jesus, Poá, Ribeirão Pires, Rio Grande da Serra, Santa Isabel, Salesópolis, Santana do Parnaíba, Santo André, São Bernardo do Campo, São Caetano do Sul, Suzano e Taboão da Serra. 
Da mesma forma, em relação aos serviços comuns aos municípios considerados de interesse metropolitano, o artigo $5^{\circ}$ da legislação federal foi repetido no artigo $2^{\circ}$ da Lei Complementar $n^{\circ} 94 / 74^{38}$.

O texto estadual atribui competência ao Estado para a realização do planejamento integrado da região metropolitana e sua execução, bem como o estabelecimento de normas para o seu cumprimento e controle e a elaboração de programas e projetos dos serviços comuns de interesse metropolitano, harmonizando-os com as diretrizes do planejamento do desenvolvimento nacional e estadual ${ }^{39}$.

Seguindo ainda as diretrizes da União, o texto normativo criou o Conselho Deliberativo da Grande São Paulo - CODEGRAN e o Conselho Consultivo Metropolitano de Desenvolvimento Integrado da Grande São Paulo - CONSULTI. Ao primeiro órgão compete a promoção da elaboração e a permanente atualização do Plano Metropolitano de Desenvolvimento Integrado da Grande São Paulo, a coordenação, acompanhamento e execução desse plano, bem como emitir opiniões e decisões sobre as questões que lhe sejam submetidas pelo CONSULTI. Este, por sua vez, é um órgão basicamente consultivo, que deve opinar, por solicitação do CODEGRAN, sobre questões de interesse da Região Metropolitana da Grande São Paulo e sugerir ao CODEGRAN a elaboração de planos regionais e a adoção de providências relativas à execução dos serviços da Região Metropolitana da Grande São Paulo.

Ainda, na Lei Complementar Estadual, houve a autorização da constituição de sociedade por ações sob a denominação de Empresa Metropolitana de Planejamento da Grande São Paulo S.A. - EMPLASA, vinculada à Secretaria de Economia e Planejamento, que possuía o objetivo de realizar serviços necessários ao planejamento, programação, coordenação e controle da execução dos serviços de interesse metropolitano.

\footnotetext{
38 Tais serviços são: I - planejamento integrado do desenvolvimento econômico e social; II - saneamento básico, notadamente abastecimento de água e rede de esgotos e serviço de limpeza pública; III - uso do solo metropolitano; IV - transportes e sistema viário; V - produção e distribuição de gás combustível canalizado; VI - aproveitamento dos recursos hídricos e controle da poluição ambiental, na forma que dispuser a lei federal; e VII - outros serviços que assim forem definidos por lei federal.

39 Além dessas referências, duas outras merecem destaque, e estão no artigo $3^{\circ}$, VII e VIII: "VII - o estabelecimento de normas gerais sobre a execução dos serviços comuns de interesse metropolitano e o seu cumprimento e controle; e VIII - a declaração e reserva de áreas de interesse metropolitano, bem assim o estabelecimento de limitações administrativas sobre essas áreas, de conformidade com as normas reguladoras do uso do solo metropolitano".
} 


\subsubsection{Decreto Estadual $n^{0}$ 6.111/75, Lei Complementar Estadual $n^{0} 144 / 1976$ e Lei Estadual no 1.492/1977}

Diante do novo contexto e da necessidade de adequação às normas federais e estaduais sobre a matéria, o Decreto Estadual $n^{\circ}$ 6111, de 5 de maio de 1975, que regulamentou a Lei Complementar $n^{\circ}$ 94/74, criou e institucionalizou o denominado Sistema de Planejamento e Administração Metropolitana - SPAM, cujo objetivo era promover a coordenação das atividades governamentais, de modo a assegurar o desenvolvimento integrado da Região Metropolitana da Grande São Paulo. O referido sistema é composto por (a) Conselho Consultivo Metropolitano de Desenvolvimento Integrado da Grande São Paulo (CONSULTI), unidade consultiva; (b) Conselho Deliberativo da Grande São Paulo - CODEGRAN, unidade deliberativa e normativa; (c) Secretaria de Estado dos Negócios Metropolitanos, unidade coordenadora e operadora; (d) Empresa Metropolitana de Planejamento da Grande São Paulo S.A. - EMPLASA, unidade técnica e executiva ${ }^{40}$; (e) Fundo Metropolitano de Financiamento e Investimento a respectivo Conselho de Orientação, unidade financiadora; e (f) outros órgãos e entidades atuantes na Região Metropolitana da Grande São Paulo, diretamente relacionados com os serviços comuns de interesse metropolitano.

Em sequência, a Lei Complementar Estadual $n^{\circ}$ 144, de 22 de setembro de 1976, fez algumas alterações pontuais na Lei Complementar Estadual no 94/74. Esta foi seguida pela Lei Estadual n 1.492, de 13 de dezembro de 1977, que estabeleceu o Sistema Metropolitano de Transportes Urbanos e autorizou a criação da Empresa Metropolitana de Transportes Urbanos de São Paulo S.A. - EMTU.

Sobre esta lei, deve-se fazer algumas observações. A Empresa Metropolitana de Transportes Urbanos de São Paulo S.A. - EMTU/SP foi declarada concessionária exclusiva $^{41}$ dos sistemas de transportes públicos, sobre trilhos (metrô, ferrovias de subúrbios e outros), sobre pneus, hidroviário e de pedestres, operados nas áreas urbanas e as conexões intermodais de transportes, tais como estacionamentos, terminais e outras não expressas na lei. A finalidade da empresa era integrada: promover a efetivação das

\footnotetext{
${ }^{40}$ Basicamente a EMPLASA era um órgão técnico e executivo de política metropolitana e responsável, à época, pela elaboração de planos e projetos referentes à área metropolitana e pela análise de concessão de licenciamento de empreendimentos.
}

41 Segundo o artigo $4^{\circ}$, parágrafo único, da referida lei, a concessão outorgada é de 50 anos. 
diretrizes, condições e normas gerais, aprovadas pelo CODEGRAN e relativas ao Sistema Metropolitano de Transportes Públicos de Passageiros da Região Metropolitana da Grande São Paulo, com especial destaque a algumas atividades: realizar o planejamento dos serviços compreendidos no Sistema Metropolitano de Transportes Públicos de Passageiros e promover e coordenar a operação, a implantação, a administração e a expansão dos serviços e dos planos do Sistema Metropolitano de Transportes Públicos de Passageiros. Para regulamentar esta lei, foi editado o Decreto Estadual $n^{\circ} 10.951$, de 13 de dezembro de 1977, que reorganizou a Secretaria de Estado dos Negócios Metropolitanos - SNM, estabelecendo seu campo funcional.

Alguns anos depois, o Decreto $\mathrm{n}^{\mathrm{o}} 24.675$, de 30 de janeiro de 1986, regulamentou os serviços metropolitanos de transporte coletivo regular de passageiros, por ônibus, na Região Metropolitana de São Paulo. Neste diploma, estabeleceu-se a competência da Secretaria dos Negócios Metropolitanos o planejamento, criação, implantação, coordenação, execução, regulamentação, controle e fiscalização dos serviços metropolitanos de transporte coletivo regular dos passageiros, por ônibus, na Região Metropolitana, bem como a aplicação das sanções e fixação das tarifas. O referido decreto classificou as linhas metropolitanas em comuns e seletivas, definindo como comuns aquelas utilizadas por veículos do tipo urbano, permitido o transporte de passageiro em pé, enquanto que as seletivas utilizam-se de veículos especiais, com vedação expressa ao transporte de passageiro em é $^{42}$. A norma ainda prevê a delegação da execução dos serviços a empresas qualificadas mediante permissão ou autorização.

\subsubsection{Leis metropolitanas}

A partir do estabelecimento das regiões metropolitanas, houve um movimento para a aprovação de leis que contemplassem a região de São Paulo e delimitassem o uso do solo para a proteção de mananciais e disciplinassem o zoneamento industrial da região, matérias essenciais para delimitar o crescimento urbano da região.

A primeira lei de interesse metropolitano foi a Lei Estadual $n^{\circ} 898 / 75$, que disciplina o uso do solo para a proteção dos mananciais, cursos e reservatórios de água e

${ }^{42}$ Classificação ainda utilizada, conforme se verá adiante. 
demais recursos hídricos de interesse da Região Metropolitana da Grande São Paulo, cumprindo o disposto nos incisos II e III do artigo $2^{\circ}$ e o inciso VIII do artigo $3^{\circ}$, todos da Lei Complementar $n^{\circ}$ 94/74. Nas áreas consideradas de proteção, a referida lei prevê a necessidade de autorização aos projetos e à execução de arruamentos, loteamentos, edificações e obras, bem como à prática de atividades agropecuárias, comerciais, industriais e recreativas. Dispõe, ainda, sobre a fiscalização a ser exercida e as penalidades a serem aplicadas.

Em seguida, a Lei Estadual $n^{\circ} 1.172 / 76$ foi aprovada para delimitar as áreas de proteção relativa aos mananciais, cursos e reservatórios de água a que se refere o artigo $2^{\circ}$ da Lei $n^{\circ} 898 / 75$, classificando-as como áreas ou faixas de primeira e segunda categoria. As áreas e faixas de $1^{a}$ categoria devem ser preservadas e ter proteção especial, enquanto que as áreas de $2^{\mathrm{a}}$ categoria são mais apropriadas à ocupação. Esta última categoria é ainda subdividida em três classes, de acordo com a proximidade da área de primeira categoria. Esta lei enfrentou inúmeros problemas, dentre os quais conflitos com os municípios pertencentes à região metropolitana, desvalorização das áreas próximas aos reservatórios, induzindo a comercialização de modo clandestino e aumentando a concentração de moradias de baixa renda.

Para regulamentar as leis aprovadas, o Decreto $n^{\circ}$ 9714/77 dispõe sobre o regulamento e o disciplinamento do uso do solo para a proteção aos mananciais da Região Metropolitana da Grande São Paulo, com a atribuição de funções aos órgãos públicos envolvidos e disposição sobre o procedimento para aprovação e licenciamento de projetos de arruamentos, loteamentos, edificações, obras, reformas, ampliações de edificações, existentes, instalações de estabelecimentos, alterações de uso, bem como a prática de atividades agropecuárias, hortifrutícolas, comerciais, industriais e recreativas nas áreas de proteção.

Mais tarde, o zoneamento industrial na Região Metropolitana da Grande São Paulo foi estabelecido pela Lei $\mathrm{n}^{\circ} 1817$, de 27 de outubro de 1978, com o objetivo de disciplinar a localização, a classificação e dar diretrizes para o licenciamento de estabelecimentos industriais. Esta lei direcionou o desenvolvimento industrial da região, retirando da região as indústrias que não se adequariam as exigências normativas.

O que se observa a partir dessas leis é um posicionamento do Estado para usurpar as competências que são típicas dos municípios. Deve-se ressaltar, entretanto, que 
tais normas estão inseridos no contexto brasileiro de ditadura militar, antes da visão democrática hoje reinante, e estão em consonância com o disposto no artigo $5^{\mathrm{a}}$, III, da Lei Complementar $\mathrm{n}^{\circ}$ 14/73.

\subsubsection{A Constituição Estadual e os contornos modernos da Região Metropolitana de São Paulo.}

Com o advento da Constituição Federal de 1988, a competência para o desenvolvimento de políticas de gestão das regiões metropolitanas foi repassada aos Estados, seguindo a orientação de descentralização proposta com o fim da ditadura.

A partir daí, algumas medidas foram tomadas pelo Estado de São Paulo. O Decreto $\mathrm{n}^{\mathrm{o}}$ 29.355, de 14 de dezembro de 1988, determinou que a Secretaria dos Negócios Metropolitanos passasse a se denominar Secretaria da Habitação e Desenvolvimento Urbano, para a qual foram transferidas as atribuições, bens móveis, equipamentos direitos e obrigações, da extinta Secretaria da Habitação. Ainda, passaram a vincular-se a esta Secretaria a Companhia de Desenvolvimento Habitacional do Estado de São Paulo - CDH,

a Empresa Metropolitana de Transportes Urbanos S.A. - EMTU e a Empresa Metropolitana de Planejamento da Grande São Paulo S.A. - EMPLASA.

Com o advento da Constituição Estadual, de 5 de outubro de 1989, a Região Metropolitana passou a ser tratada no capítulo II - Da Organização Regional. O art. 152 da referida norma estabelece os objetivos da organização regional:

Artigo 152 - A organização regional do Estado tem por objetivo promover:

I - o planejamento regional para o desenvolvimento sócio-econômico e melhoria da qualidade de vida;

II - a cooperação dos diferentes níveis de governo, mediante a descentralização, articulação e integração de seus órgãos e entidades da administração direta e indireta com atuação na região, visando ao máximo aproveitamento dos recursos públicos a ela destinados;

III - a utilização racional do território, dos recursos naturais, culturais e a proteção do meio ambiente, mediante o controle da implantação dos empreendimentos públicos e privados na região;

IV - a integração do planejamento e da execução de funções públicas de interesse comum aos entes públicos atuantes na região;

$\mathrm{V}$ - a redução das desigualdades sociais e regionais. 
Parágrafo único - O Poder Executivo coordenará e compatibilizará os planos e sistemas de caráter regional.

Percebe-se, com a leitura do artigo, que o constituinte estadual deu continuidade aos princípios previstos na Constituição Federal de 1988, em especial ao disposto no artigo $3^{\circ}$, I, II e III, que prevê os objetivos fundamentais da República Federativa do Brasil ${ }^{43}$, e no artigo 174 , parágrafo primeiro ${ }^{44}$.

Nesse contexto, autoriza a Constituição a divisão do território estadual em "unidades regionais constituídas por agrupamentos de municípios limítrofes mediante lei complementar, a fim de integrar a organização, o planejamento e a execução de funções públicas de interesse comum, atendidas as respectivas peculiaridades", conforme expresso no artigo 153, da Constituição Estadual. O legislador constituinte estadual de 1989 fez uma diferenciação das espécies de unidades regionais, definindo os conceitos de região metropolitana, aglomeração urbana e microrregião, que não havia sido elaborada pelo constituinte federal, que por sua vez somente facultou aos estados suas criações. No parágrafo primeiro do referido artigo, há a definição do que se considera região metropolitana:

$\S 1^{\circ}$ - Considera-se região metropolitana o agrupamento de Municípios limítrofes que assuma destacada expressão nacional, em razão de elevada densidade demográfica, significativa conurbação e de funções urbanas e regionais com alto grau de diversidade, especialização e integração sócio-econômica, exigindo planejamento integrado e ação conjunta permanente dos entes públicos nela atuantes.

A Constituição fornece, ainda, nos parágrafos seguintes, os conceitos de aglomeração urbana e microrregião ${ }^{45}$. Há a previsão, também, da criação de conselhos de

\footnotetext{
${ }^{43}$ Art. $3^{\circ}$ Constituem objetivos fundamentais da República Federativa do Brasil:

I - construir uma sociedade livre, justa e solidária;

II - garantir o desenvolvimento nacional;

III - erradicar a pobreza e a marginalização e reduzir as desigualdades sociais e regionais;

${ }^{44}$ Art. 174. Como agente normativo e regulador da atividade econômica, o Estado exercerá, na forma da lei, as funções de fiscalização, incentivo e planejamento, sendo este determinante para o setor público e indicativo para o setor privado.
}

$\S 1^{\circ}$ - A lei estabelecerá as diretrizes e bases do planejamento do desenvolvimento nacional equilibrado, o qual incorporará e compatibilizará os planos nacionais e regionais de desenvolvimento.

45 “\$2 - Considera-se aglomeração urbana o agrupamento de Municípios limítrofes que apresente relação de integração funcional de natureza econômico-social e urbanização contínua entre dois ou mais Municípios ou 
caráter normativo e deliberativo, nos quais os municípios teriam alguma participação, ainda que esta devesse ser regulamentada em lei, e da participação da população no planejamento, na tomada de decisões e na fiscalização dos serviços metropolitanos ${ }^{46}$.

Um ponto importante a se destacar é a previsão de que os municípios devem compatibilizar, no que couber, seus planos, programas, orçamentos, investimentos e ações às metas, diretrizes e objetivos estabelecidos nos planos e programas regionais e, da mesma forma, o Estado, no que couber, compatibilizará os planos e programas estaduais, regionais e setoriais de desenvolvimento, com o plano diretor dos Municípios e as prioridades da população local ${ }^{47}$.

Em relação ao transporte coletivo, prevê o artigo 158, caput e parágrafo único, do diploma constitucional, que em região metropolitana o planejamento do transporte coletivo de caráter regional será efetuado pelo Estado, diretamente ou mediante concessão ou permissão, em conjunto com os Municípios integrantes das respectivas entidades regionais ${ }^{48}$

Neste ponto, deve-ser observar que o Estado impõe aos municípios uma observância que pode ser questionada já que fere a autonomia municipal. A exigência de compatibilização de planos é, de certa forma, um abuso da autoridade estadual. Ao que aparenta, com esse dispositivo, o Governo Estadual busca controlar as metrópoles e direcionar seu crescimento.

Ainda que a transferência da competência sobre as regiões metropolitanas da União para o Estado seja uma evolução, uma vez que este possui melhor conhecimento da realidade metropolitana, esta não deve ser a melhor forma de organização possível. Uma maior participação dos municípios e da população envolvidos seria um melhor cenário para a organização da região metropolitana.

manifesta tendência nesse sentido, que exija planejamento integrado e recomende ação coordenada dos entes públicos nela atuantes.

$\S 3^{\circ}$ - Considera-se microrregião o agrupamento de Municípios limítrofes que apresente, entre si, relações de interação funcional de natureza físico-territorial, econômico-social e administrativa, exigindo planejamento integrado com vistas a criar condições adequadas para o desenvolvimento e integração regional".

${ }^{46}$ Artigo 154, § 2º da Constituição Estadual.

${ }^{47}$ Esta previsão está no artigo 155, caput e parágrafo único, da Constituição Estadual.

${ }^{48}$ Neste ponto, a Constituição revogou o que era previsto no Decreto $\mathrm{n}^{\circ}$ 24.675/86, que, em seu artigo 12 , previa que os contratos seriam feitos mediante autorização ou permissão. 


\subsubsection{Lei Complementar Estadual no $760 / 94$}

A Lei Complementar Estadual $\mathrm{n}^{\circ} 760$, de $1^{\circ}$ de agosto de 1994, estabelece as diretrizes para a organização regional do Estado de São Paulo, em consonância com as Constituições Federal e Estadual vigentes. Num primeiro momento se enumera os objetivos dessa organização ${ }^{49} \mathrm{e}$, em seguida, no artigo $3^{\circ}$ enuncia o que considera região metropolitana, acrescentando mais especificidades para sua caracterização, se aproximando de critérios mais objetivos:

Art. $3^{\circ}$ - Considerar-se-á região metropolitana o agrupamento de municípios limítrofes, com destacada expressão nacional, a exigir planejamento integrado e ação conjunta com união permanente de esforços para a execução das funções públicas de interesse comum, dos entes públicos nela atuantes, que apresente, cumulativamente, as seguintes características:

I - elevada densidade demográfica;

II - significativa conurbação;

III - funções urbanas e regionais com alto grau de diversidade; e

IV - especialização e integração socioeconômica.

No artigo $7^{\circ}$, a Lei Complementar elenca uma série de funções que podem ser entendidas como sendo de interesse comum dentro das unidades regionais. Tal rol, entretanto, não é taxativo, como se pode depreender da simples leitura do caput do artigo, que expressa que "[p]oderão ser considerados" e não um simples "serão" ou outras variações. Desta forma, novas funções podem passar a ser de interesse comum com o desenvolvimento urbano e o surgimento de novas necessidades que envolvam as cidades

${ }^{49}$ Os objetivos numerados seguem os ditames do artigo 152, da Constituição Estadual:

“Art. $1^{\circ}$ - A Organização Regional do Estado de São Paulo terá por objetivo promover:

I - o planejamento regional para desenvolvimento sócio-econômico e melhoria de qualidade de vida;

II - a cooperação dos diferentes níveis de governo, mediante a descentralização, articulação e integração de seus órgãos e entidades da administração direta e indireta atuantes na região, visando ao máximo aproveitamento dos recursos públicos a ela destinados;

III - a utilização racional do território, dos recursos naturais e culturais e a proteção do meio ambiente, mediante o controle da implantação dos empreendimentos públicos e privados na região;

IV - a integração do planejamento e da execução de funções públicas de interesse comum aos entes públicos atuantes na região; e

V - a redução das desigualdades sociais e regionais." 
de determinada unidade regional. As funções de interesse comum expressas pelo artigo são: I - planejamento e uso de solo; II - transporte e sistema viário regionais; III habitação; IV - saneamento básico; V - meio ambiente; VI - desenvolvimento econômico; e VII - atendimento social ${ }^{50}$.

O referido texto normativo prevê ainda, a criação de um Conselho de Desenvolvimento, de caráter normativo e deliberativo, para cada unidade regional, paritário, formado por representantes dos municípios e do estado $^{51}$, assegurada a participação popular nos termos da previstos na lei. Este Conselho, segundo o artigo 17 da Lei Complementar, integrará entidade com personalidade jurídica de direito público, autonomia administrativa e financeira, que será criada por lei com o propósito de integrar a organização, o planejamento e a execução - sem prejuízo da competência das entidades envolvidas - das funções públicas de interesse comum.

\subsubsection{O transporte coletivo na Região Metropolitana de São Paulo}

Em 1991, a Secretaria de Habitação e Desenvolvimento Urbano passou a denominar-se Secretaria da Habitação e a questão pertinente aos transportes da região metropolitana foram administrados provisoriamente pela Secretaria de Planejamento e Gestão, de acordo com o Decreto Estadual n ${ }^{\circ} 33.145$, de 20 de março de 1991, permanecendo ali até a criação da Secretaria de Estado dos Transportes Metropolitanos.

A necessidade de um órgão que cuidasse especificamente do transporte metropolitano resultou na Lei Estadual $n^{\circ} 7.450$, de 16 de julho de 1991, que criou a Secretaria de Estado dos Transportes Metropolitanos. A organização desta Secretaria se deu pelo Decreto Estadual no 34.184, de 18 de novembro de 1991, que estabeleceu seus campos funcionais que eram, basicamente, a execução da política de transportes na Região Metropolitana de São Paulo e o sistema viário metropolitano.

${ }^{50}$ É importante destacar que os parágrafos primeiro e segundo do referido artigo destacam que o planejamento dos serviços de transporte são de competência do Estado e dos municípios integrantes das respectivas entidades regionais, mas a operação do transporte coletivo regional é feita pelo Estado, diretamente ou mediante concessão ou permissão.

${ }^{51}$ Segundo o parágrafo único do artigo $8^{\circ}$ : "Fica assegurada a participação paritária do conjunto dos Municípios, em relação ao Estado, na organização, articulação, coordenação e fusão das entidades e órgãos públicos que desempenhem as funções públicas de interesse comum na unidade regional". Isto é repisado no parágrafo segundo do artigo seguinte. 
Num primeiro momento eram vinculadas a esta Secretaria a Companhia do Metropolitano de São Paulo (Metrô) e a Empresa Metropolitana de Transportes Urbanos (EMTU/SP). Posteriormente, foram integrados por determinação do Decreto Estadual $n^{\circ}$ 39.895, de $1^{\circ}$ de janeiro de 1995, a Empresa de Planejamento da Grande São Paulo S.A. (EMPLASA, cuja denominação atual é Empresa Paulista de Planejamento S.A.) e o Fundo Metropolitano de Financiamento (FUMEFI), que foram desvinculados em 2003. Em 1992, pela Lei Estadual $n^{\circ} 7.861$, de 28 de maio, foi criada a Companhia Paulista de Trens Metropolitanos - CPTM.

Atualmente, a Secretaria dos Transportes Metropolitanos é responsável pelo transporte urbano metropolitano de passageiros nas quatro regiões metropolitanas paulistas: a de São Paulo, da Baixada Santista, de Campinas e do Vale do Paraíba, sendo que essas três últimas foram incorporadas como área de atuação no momento de sua criação, sendo, respectivamente, em 1996, 2000 e 2012.

Antes, porém, de avançar na questão do transporte na região metropolitana de São Paulo, cabe fazer algumas anotações quanto ao que é delegação de serviço público e como ela se dá, dados fundamentais para prosseguir o estudo. 


\section{DELEGAÇÃO DE SERVIÇO PÚBLICO}

A fim de se entender como são feitas as delegações de transporte nas regiões metropolitanas, é importante verificar o que é um serviço público, se o transporte é um serviço público, quais são as formas de delegação e como se dá a remuneração desse serviço. É importante observar que esses são os fundamentos do que será analisado adiante: os contratos existentes na região metropolitana.

\subsection{Noção de serviço público}

A noção de serviço público deve ser analisada, preliminarmente, para compreendermos melhor seus desdobramentos. O professor Eros Roberto Grau ${ }^{52}$ nos ensina que na Constituição Federal observamos a existência da expressão atividade econômica que se desdobra em duas outras expressões: atividade econômica em sentido estrito e serviço púbico. O Estado poderia atuar nesses dois níveis, de acordo com as normativas expressas no texto Maior. Caberia, então, definir a noção de serviço público para então se determinar se o transporte metropolitano estaria nela inserido.

Nem tudo o que está previsto na Constituição como incumbência do Estado, através de seus entes, é serviço público. Como já visto, há essa distinção a ser feita entre atividade econômica em sentido estrito e serviço público, que é concebida a partir da análise dos fatos concretos à luz da noção dada do tema estudado.

$\mathrm{Na}$ síntese elaborada pelo professor Eros Roberto Grau, desenvolveu-se, a partir de ensinamentos apresentados por Duguit e Cirne Lima, a noção ao nosso ver acertada de que serviço público é:

"[A] atividade explícita ou supostamente definida pela Constituição como indispensável, em determinado momento histórico, à realização e ao desenvolvimento da coesão e da interdependência social, ou, em outros termos, atividade explícita ou supostamente definida pela Constituição como serviço existencial relativamente à sociedade em um determinado momento histórico".

\footnotetext{
52 Constituição e Serviço Público, in Grau, Eros Roberto e Guerra Filho, Willis Santiago (coord.), Direito Constitucional, estudos em homenagem a Paulo Bonavides, São Paulo, Malheiros, 2001, p. 267.
} 
A partir dessa noção proposta, resta esclarecer se o transporte público realizado por ônibus em regiões metropolitanas estaria inserido nesta proposta. Esta análise deve partir de uma interpretação do conjunto constitucional existente, em especial com a observância de seus fundamentos e objetivos, estruturados nos artigos $1^{\circ}$ e $3^{\circ}$ da Carta Magna, respectivamente. Com vistas à noção apresentada, deve-se verificar se há a realização e o desenvolvimento da coesão e da interdependência social na prestação do serviço de transporte metropolitano.

Ora, parece claro que o transporte de pessoas, independente do fato de ser no interior da própria cidade, de cidades vizinhas, cidades de mesmo Estado ou entre Estados, é essencial para o desenvolvimento da coesão social. A interação da população no interior de seu próprio país leva à identidade entre aqueles que o habitam. Desta forma, propiciar o transporte público é claramente um serviço público, que deve ser garantido pelo Estado para a consecução dos objetivos constitucionais. A própria Constituição Federal, em seu artigo 30, V, prevê que o transporte coletivo tem caráter essencial.

\subsection{Evolução no Brasil da ideia de delegação de serviços públicos a particulares}

Para compreender a situação atual das concessões de serviço público, em especial as de transporte, deve-se compreender em que momento isso passou a ser uma obrigação do Estado.

O instrumento da concessão do serviço público, como ressalta a professora Maria Sylvia Zanella di Pietro ${ }^{53}$, foi uma das primeiras formas do Estado transferir a terceiros a execução de um serviço público, até mesmo porque há a exigência de grandes investimentos e pessoal técnico especializado para execução desses serviços. O contrato de concessão permite, desta forma, a transferência do ônus do financiamento e a sua execução ao setor privado, com contratos em geral de longo prazo.

No Brasil, no período do Império, as concessões eram associadas à idéia de privilégio concedido pelo Estado a determinada pessoa, sem qualquer critério de isonomia. Registros apontam que a primeira delegação de serviço público a um particular tenha

${ }^{53}$ Direito Administrativo, São Paulo: Atlas, 2012, p. 301. 
ocorrido em 1850, para a exploração de estrada de ferro nos atuais Estados de Pernambuco e Rio de Janeiro. As concessões, naquela época, eram identificadas como fator de desenvolvimento, já que estava relacionada principalmente à criação e expansão de estradas de ferro, de portos, de energia elétrica e de serviços de transporte coletivo.

A partir da década de 1930, porém, houve um declínio das concessões como instrumento da prestação de serviços públicos. Os motivos que geraram tal reação foram, basicamente, a instabilidade econômica, originada também com as guerras mundiais, e a tendência da estatização, o que levou ao aumento da intervenção estatal direta na prestação dessas atividades. A partir disso, empresas estatais foram criadas para absorver essa demanda do Estado, sendo agraciadas com a concessão de monopólios estatais, como no caso do artigo 116 da Constituição de 1934. Isso perdurou até a culminação da crise fiscal, da falta de eficiência dessas empresas na execução de suas prestações e da retomada da abertura ao capital estrangeiro.

Ao longo das décadas de 1980 e 1990, houve a adoção, pelo governo federal, de um programa nacional de desburocratização, seguido da criação do Conselho Nacional de Desburocratização, que culminou com o programa de privatização das empresas estatais brasileiras.

Em meio ao novo fenômeno das privatizações, no final da década de 1980, ressurgiu o interesse no Brasil pela concessão. Prevista na própria Constituição da República de 1988, na década de 1990 foi inaugurado novo período para as concessões, com a reformulação do papel da Administração Pública.

A edição da Lei $n^{0}$ 8.987, de 13 de fevereiro de 1995, que dispõe sobre o regime de concessão e permissão de serviços públicos, foi responsável pelo renascimento do interesse sobre o tema. Nesse período também foram editadas leis que reformularam a participação estatal em alguns serviços públicos, estabelecendo regras setoriais para a concessão dos serviços, como no caso do setor elétrico, das telecomunicações e do saneamento básico.

\subsection{Serviços delegados a particulares na dicção da Constituição de 1988}


Conforme se verifica no artigo 22, XXVII, da Constituição Federal, compete à União Federal editar normas gerais sobre licitações e contratos para a Administração Pública, direta e indireta, da União, dos Estados e Municípios. Este dispositivo é essencial para se delinear quais são as diretrizes escolhidas pelo Estado brasileiro para a realização de contratações com outras entidades, uma vez que há uma imposição de procedimento próprio para tanto, que deverão seguir regras precisas para que não haja favorecimento indevido a qualquer pessoa, seja física, seja jurídica, nem haja eventual dano ao Poder Público.

Cabe ressaltar que houve uma mudança no dispositivo citado. Anteriormente, previa-se o seguinte:

"Art. 22 Compete privativamente à União legislar sobre: (...) XXVII - normas gerais de licitação e contratação, em todas as modalidades, para a administração pública, direta e indireta, incluídas as fundações instituídas e mantidas pelo Poder Público, nas diversas esferas de governo, e empresas sob seu controle".

Posteriormente, a Emenda Constitucional $\mathrm{n}^{\circ}$ 19, de 1998, alterou o referido texto para que constasse expressamente:

"XXVII - normas gerais de licitação e contratação, em todas as modalidades, para as administrações públicas diretas, autárquicas e fundacionais da União, Estados, Distrito Federal e Municípios, obedecido o disposto no art. 37, XXI, e para as empresas públicas e sociedades de economia mista, nos termos do art. $173, \S 1^{\circ}$, III".

O que se extrai de tal mudança é que houve uma preocupação especial do constituinte derivado em detalhar a participação de todos os entes federados, de todas as pessoas jurídicas deles decorrentes, sejam parte da Administração direta ou indireta, o que confere mais confiabilidade nas contratações públicas.

Em outro dispositivo constitucional, no artigo 37, XXI, há a determinação de que as obras, serviços, compras e alienações serão contratados mediante processo de licitação pública, ressalvados os casos especificados na legislação, de forma que em tal processo se assegure igualdade de condições a todos os concorrentes, com cláusulas que 
estabeleçam obrigações de pagamento, mantidas as condições efetivas da proposta. Esse dispositivo contém comandos que introduzem importantes balizamentos a todas as normas infraconstitucionais que de qualquer forma regulem o tema da licitação e dos contratos administrativos. Do mesmo modo, há tal exigência para contratos de permissão e concessão de serviço público, como prevê o artigo 175, da Constituição Federal.

No parágrafo único do referido dispositivo, ainda, encontram-se as diretrizes necessárias para tais serviços, que estarão dispostas em lei. Tais diretrizes são: I - o regime das empresas concessionárias e permissionárias de serviços públicos, o caráter especial de seu contrato e de sua prorrogação, bem como as condições de caducidade, fiscalização e rescisão da concessão ou permissão; II - os direitos dos usuários; III - política tarifária; IV a obrigação de manter serviço adequado.

A Constituição, em seu artigo 175, parágrafo único, e a Lei no 8.987/95, em seu artigo 29, I, dispõe expressamente da competência do Poder Público em realizar a regulamentação dos serviços públicos. Isso ocorre devido ao fato da concessão ser feita no interesse da coletividade, que deve ser prestado em condições adequadas para os usuários. Caso tal não seja feito, a Administração deve retomá-lo. Assim, é o entendimento de que seja reservado ao concedente o poder de regulamentar e controlar a atuação do concessionário, desde a organização da empresa até a sua situação econômico-financeira, seus lucros, o modo e a técnica de execução dos serviços

A lei geral que disciplina os contratos administrativos é a Lei ${ }^{\circ}$ 8.666/1993. Essa lei, ainda que possua um caráter amplo, trata essencialmente de contratos de fornecimento de bem, prestação de serviço ou realização de obra por particular, cuja remuneração será a ele proporcionada pelo ente público contratante.

A Lei nº 8.987/1995, por sua vez, disciplina a concessão de serviço público, que busca a transferência da prestação de serviços e obras públicas para o particular, cuja remuneração será proporcionada como regra geral pelo usuário do serviço, com o pagamento de tarifas. Nesse contexto, a tarifa é o elemento central da proposta econômica apresentada pelo particular na licitação para outorga de concessões, já que em tese deve proporcionar ao contratante privado os valores necessários à amortização dos investimentos realizados e ao lucro almejado com o negócio que não pode ser excessivo. 
Em algumas circunstâncias, entretanto, a tarifa a ser fixada pelo Poder Público é inferior à remuneração do serviço. Nesses casos, a diferença será compensada pelo pagamento de subsídio pelo concedente, de forma a propiciar o equilíbrio contratual. Para esse fim, em contratos de grande monta, foram criados os contratos de concessão patrocinada que servem para conferir essa viabilidade econômica a serviços públicos essenciais que possuem baixa rentabilidade econômica. Não se trata nesses casos, como lembra Adílson Abreu Dallari ${ }^{54}$, de incidentalmente ou eventualmente pagar um subsídio para compensar diferenças eventuais ou episódicas. Trata-se de pagamento necessário e previsto na lei orçamentária de cada ente, suficiente e reajustável ao longo do contrato.

Estes serão alguns pontos a serem analisados abaixo.

\subsubsection{Concessão de Serviço Público}

A concessão de serviço público é um contrato administrativo no qual a Administração Pública delega a pessoa jurídica ou consórcio de empresas ${ }^{55}$ a execução de um serviço público para que este seja executado em seu nome, mediante concorrência, por sua conta e risco, assegurando a remuneração mediante tarifa paga pelo usuário ou outra forma de remuneração prevista em contrato. As normas sobre a concessão encontram-se na Lei $n^{\circ} 8.987 / 95$.

A lei do Estado de São Paulo $n^{0} 7.835 / 92$ é um pouco mais precisa quanto à definição deste contrato administrativo, em seu artigo $2^{\circ}$, III: "a delegação contratual, a empresa individual ou coletiva ou a consórcio de empresas da prestação de serviço público, por sua conta e risco e por prazo certo, remunerada basicamente pela cobrança de tarifas dos usuários". A este conceito, porém, falta referência somente ao fato da possibilidade de outras formas de remuneração, decorrentes da própria exploração do serviço, como característica surgida pelo próprio desenvolvimento do instituto.

Deve-se destacar que a delegação contratual é da execução do serviço, na forma autorizada e regulamentada pelo Executivo. Não há a transferência de propriedade

\footnotetext{
${ }^{54}$ Parcerias em Transporte Público. In: SUNDFELD, Carlos Ari (coord.). Parcerias público-privadas. 2a ed. São Paulo: Malheiros Editores, 2011. p. 380-389.

${ }^{55}$ Necessário destacar que pelo previsto na lei a pessoa física não poderá obter concessão de serviço público somente permissão, que possui um caráter precário e é formalizada por meio de um contrato de adesão.
} 
alguma ao concessionário, bem como este não terá qualquer direito ou prerrogativa púbica com a concessão.

Pelas definições legais, deve-se acrescentar as características do contrato apontadas pela doutrina, que são: ajuste de Direito Administrativo, bilateral, oneroso, comutativo e realizado intuitu personae. Através desta definição fica claro que não se trata de um ato unilateral da administração, uma vez que há vantagens e encargos recíprocos, com a necessária atenção aos interesses coletivos e às condições daquele que irá executálo.

Apesar do serviço ser concedido, como bem destaca o professor Hely Lopes Meirelles ${ }^{56}$, o poder concedente nunca se despoja do direito de explorá-lo direita ou indiretamente, desde que o interesse público assim o exija. Assim, o ente público pode retomar o serviço concedido, mediante indenização ao concessionário dos lucros cessantes e dos danos emergentes, indenização esta que poderá estar prevista em contrato ou, caso esteja omitida, pode ser apurada de forma amigável ou judicialmente.

Em geral, a concessão deve ser conferida sem exclusividade, a fim de viabilizar a competição entre interessados para favorecer os usuários com serviços em tese melhores e mais baratos. A exceção a esta regra é a exclusividade da prestação do serviço que deve ser justificada, conforme previsão no artigo 16, da Lei nº 8.987/95.

Como contrato administrativo, deve-se destacar que tal instituto contém as chamadas cláusulas exorbitantes, que conferem ao concedente os poderes de alterar e rescindir unilateralmente o contrato, bem como fiscalizar sua execução e, em certos casos, aplicar penalidades. Da mesma forma, podem-se aplicar a esses contratos as teorias do fato do príncipe e da imprevisão.

Por outro lado, o contrato possui também as cláusulas financeiras, que concernem ao seu equilíbrio econômico-financeiro. A este respeito deve-se fazer algumas observações.

Se por um lado, o serviço público deve funcionar no interesse social e sob a autoridade da Administração, por outro, a empresa concessionária é capitalista e, como tal, deve buscar o máximo proveito possível com o contrato realizado.

${ }^{56}$ Direito Administrativo Brasileiro. $35^{\mathrm{a}}$ ed. São Paulo: Malheiros, 2009, p. 390. 
Como consequência do objeto da concessão ser a execução de serviço público, há de se estabelecer cláusulas regulamentares, já destacadas, e a outorga de prerrogativas públicas ao concessionário. Ainda, há a sujeição do concessionário aos princípios inerentes à prestação de serviços públicos, como a continuidade, mutabilidade e igualdade dos usuários, bem como eventual responsabilização civil regida por normas publicistas. Não se poderia afastar o direito inerente ao poder concedente da eventual reversão de bens da concessionária ao poder concedente, com o reconhecimento da natureza pública dos bens da concessionária afetados à prestação do serviço. Por fim, é resultado da concessão efeitos intitulados trilaterais, por afetarem poder concedente concessionário e os usuários.

\subsubsection{Permissão de Serviço Público}

A permissão de serviço público é considerada tradicionalmente um ato unilateral, discricionário e precário, "pelo qual o Poder Público transfere a outrem a execução de um serviço público, para que o exerça em seu próprio nome e por sua conta e risco, mediante tarifa paga pelo usuário" ${ }^{57}$.

Distingue-se a permissão da concessão pelo caráter precário da primeira, que, pelas palavras do professor Celso Antonio Bandeira de Mello ${ }^{58}$, seria utilizada quando o permissionário não necessitasse alocar grandes capitais para o desempenho do serviço público, quando pudesse mobilizá-lo para destinação diversa sem maiores transtornos o equipamento utilizado, quando o serviço não envolvesse implantação física de aparelhamento que aderisse ao solo ou quando os riscos da precariedade assumidos fossem compensáveis pela rentabilidade do serviço ou pelo curto prazo em que se realizaria a satisfação econômica almejada.

Já o professor Hely Lopes Meirelles ${ }^{59}$ acrescenta a essas hipóteses aqueles serviços que são transitórios ou permanentes que exijam frequentes modificações para acompanhar a evolução da técnica ou as variações do interesse público. Neste ponto, ele

\footnotetext{
${ }^{57}$ Maria Sylvia Zanella di Pietro, Direito Administrativo, São Paulo: Atlas, 2013, p. 310.

${ }^{58}$ Curso de Direito Administrativo. 30 a ed. São Paulo: Malheiros, 2013, p. 775

${ }^{59}$ Direito Administrativo Brasileiro, $35^{\text {a }}$ ed., São Paulo: Malheiros, 2009, p. 408.
} 
ressalta como exemplos o transporte coletivo, o abastecimento da população, dentre outros serviços de controle estatal ${ }^{60}$.

Assim como as concessões, a permissão depende de licitação, seu objeto é a execução de serviço público, continuando a titularidade do serviço com o Poder Público, executado em nome do permissionário, por sua conta e risco, sujeito às condições estabelecidas pela Administração e à sua fiscalização.

Cabe frisar que a permissão é deferida intuitu personae e não admite substituição do permissionário, nem possibilita a atuação de terceiros sem prévio assentimento do permitente.

O professor Celso Antônio Bandeira de Mello ${ }^{61}$ destaca que o uso da permissão vem sendo desnaturado, com a fixação de prazo pela Administração. A partir desta situação o referido autor descreve que os estudiosos se dividem nas seguintes orientações: a) Uns entendem que a designação da permissão não pode depreender precariedade, já que se trata de um contrato, ou consideram a permissão imprópria a designação adotada para a relação jurídica e os efeitos do ato equiparam-se ou quase equiparam-se aos de uma concessão; b) outros consideram tratar-se de uma normação excepcional da permissão e sustentam que por isso teria regime diverso do que é normal, com maiores garantias ao permissionário; c) outros, ainda, consideram que existem duas modalidades de permissão: uma simples, sem prazo, e outra qualificada, que teria prazo e poderia ser aplicada indenização; d) há os que defendem que não há permissão após a Constituição de 1988, já que houve de certa medida uma equiparação entre os institutos da concessão e da permissão.

Diante disso, independente do que se defenda, em todos os casos há uma clara mudança do regime inicial da permissão, com a possibilidade de indenização ao permissionário em caso de extinção do contrato antes do prazo avençado. Entendo que não se pode desnaturar a permissão, cuja característica principal é a precariedade, sob pena de a equiparar com a concessão, devendo ser tratada como tal.

\footnotetext{
${ }^{60}$ Celso Antônio Bandeira de Mello (Curso de Direito Administrativo, 30 a ed., São Paulo: Malheiros, 2013, p. 776-779) se opõe ao autor, uma vez que o transporte coletivo de passageiros seria um serviço que demanda permanência, estabilidade e garantias razoáveis em prol de seu prestador. Ressalta Bandeira de Mello que há um investimento de considerável monta nesses casos.

${ }^{61}$ Curso de Direito Administrativo, 30ª ed. São Paulo: Malheiros, 2013, p. 776-779.
} 


\subsubsection{Concessão Patrocinada}

O contrato administrativo de concessão patrocinada nada mais é do que a concessão de serviços públicos ou de obras públicas de que trata a Lei no 8.987, de 13 de fevereiro de 1995, quando envolver, adicionalmente à tarifa cobrada dos usuários, contraprestação pecuniária do parceiro público ao parceiro privado, conforme expressamente prevê o artigo $2^{\circ}, \S 1^{\circ}$, a Lei no $11.079 / 04$.

Ainda que o discurso político vinculado à criação da referida lei se justifique com crise fiscal e de capacidade de investimento do Estado brasileiro de então, havia uma tendência anterior verificada na prática da adoção de pagamentos aos concessionários para viabilizar algumas concessões de serviço público. De fato, no artigo 17 da Lei no 8.987/95 há a previsão de subsídio pelo poder público na concessão tradicional.

Outras diferenças também podem ser anotadas entre as concessões tradicionais e as patrocinadas: nas parcerias público privadas os riscos são repartidos com o parceiro público, o poder público presta garantias ao parceiro privado e ao financiador do projeto e os ganhos econômicos decorrentes da redução do risco de crédito dos financiamentos utilizados pelo parceiro privado são compartilhados entre os parceiros ${ }^{62}$.

Além dessas diferenças, outras distinções referentes ao regime jurídico das parcerias público privadas são: a obrigatoriedade de constituição de sociedade de propósitos específicos para implantar e gerir o objeto da parceria, normas específicas sobre licitação, derrogando em parte as normas das leis $n^{\circ} 8.666 / 93$ e 8.987/95, possibilidade de aplicação de penalidades à Administração Pública em caso de inadimplemento contratual, normas limitadoras do prazo mínimo e máximo do contrato, imposição de limite de despesa nesses contratos e, por último, há um valor mínimo exigido para que haja tal contrato que é de vinte milhões de reais.

Uma questão a se destacar é que a contribuição do parceiro público não pode ser superior a $70 \%$ da remuneração total a ser recebida pelo parceiro privado, a não ser que tenha autorização legislativa específica.

\footnotetext{
${ }^{62}$ Maria Sylvia Zanella di Pietro, Direito Administrativo, São Paulo: Atlas, 2013, p. 316.
} 
O que se verifica é que os contratos de parceria público privada são específicos para contratos de grande monta, que não são viáveis financeiramente para a iniciativa privada sem alguns incentivos, já que exigem alto investimento muitas vezes sem garantias de um retorno adequado.

\subsection{Remuneração}

Estão previstas, na lei no 8.987/95, como remuneração do concessionário, além da tarifa, outras fontes de receitas alternativas, complementares, acessórias ou de projetos associados, com ou sem exclusividade, com vistas a favorecer a modicidade das tarifas.

Ainda que o artigo $9^{\circ}$, caput, da lei ${ }^{\circ} 8.987 / 95$, estabeleça que será fixada pelo preço da proposta vencedora da licitação, deve-se entender que depende da licitação no caso concreto, já que há a possibilidade de fixação da tarifa pelo poder concedente. $\mathrm{O}$ critério adotado para julgamento das propostas, previsto em cada edital, deverá ser analisado para tanto. Nesse sentido, vale notar que o artigo 15 do mesmo texto normativo prevê sete critérios distintos para julgamento do certame. Desta forma, se o critério for outro que não seja o da menor tarifa, o poder concedente definirá o valor da tarifa e os critérios de reajuste, cabendo ao licitante somente a indicação do valor da oferta pela outorga ou da proposta técnica.

Deve-se ressaltar que a rentabilidade do serviço de transporte público urbano é sensível a pequenas variações no valor da tarifa, razão pela qual a possibilidade de outras formas de receita para alcançar o equilíbrio entre as partes é essencial, caso seja necessário manter um valor baixo para a tarifa.

As demais fontes de receita devem estar previstas no edital e obrigatoriamente devem ser consideradas para a aferição do inicial equilíbrio econômico-financeiro do contrato. Alguns exemplos de outras fontes de receita são a exploração publicitária e a utilização de espaço para comércio.

\subsubsection{Cálculo da tarifa}


O Poder Público se utiliza, na maior parte das vezes, da planilha de custos criada pela Empresa Brasileira de Planejamento de Transporte (GEIPOT) para a definição de tarifas de ônibus urbanos. Ela é utilizada, por exemplo, para a definição da tarifa no Município de São Paulo ${ }^{63}$.

Essa planilha remunera o custo do serviço e o custo do capital no estado do momento exato da análise, como consequência, ela não leva em conta os investimentos, o serviço e o retorno a médio e longo prazo. O modelo de planilha tarifária do GEIPOT remunera os custos do operador, dividindo-os em custos variáveis e custos fixos, sendo que os primeiros dependem da quilometragem percorrida, enquanto que o segundo independe deste fator. Compreendem os custos variáveis o combustível, lubrificantes, rodagem, peças e acessórios. Já os custos fixos abarcam o custo de capital (depreciação e remuneração), despesas com pessoal e despesas administrativas. Para o custo total do serviço, seria necessário somar os custos variáveis e fixos e os tributos incidentes. A tarifa seria auferida a partir do rateio do custo total com os usuários equivalentes ${ }^{64}$ do sistema.

Como em alguns contratos há a previsão do pagamento de outorga e custo de gerenciamento operacional, estes devem ser incluídos no custo para a aferição da tarifa. Nos contratos que serão analisados a seguir, há a previsão dessas duas despesas por parte do concessionário.

\subsubsection{Sistemas de tarifação no transporte público}

\footnotetext{
Tabelas disponíveis no site http://www.prefeitura.sp.gov.br/cidade/secretarias/transportes/transparencia/receita_e_despesas/index.php?p $=150849$, acessado em 12/01/2014.

${ }^{64}$ Não havendo tarifa com desconto, o custo dos serviços é rateado entre os passageiros pagantes. Porém, como existem descontos para determinadas categorias de usuários, é necessário calcular o número de passageiros equivalentes que se dá da seguinte maneira: faz-se um levantamento do número de passageiros que pagam tarifa integral no mês, do número de passageiros transportados nas diversas categorias de desconto $(\mathrm{x} \%)$ para o mesmo mês; multiplica-se o número de passageiros de cada categoria de desconto pelo respectivo fator de equivalência $(1-\mathrm{x} \% / 100)$; soma-se o número de passageiros com tarifa integral aos resultados dos produtos dos passageiros com desconto pelo seus fatores de equivalência. Esta informação está no site do GEIPOT: http://www.geipot.gov.br/estudos realizados/cartilha01/ANEXO\%20I.htm, acessado em 10/01/2014.
} 
Basicamente, existem três sistemas de tarifação para o transporte coletivo urbano: tarifa única, tarifa zonal e tarifa por seções ${ }^{65}$. No primeiro sistema, utilizado na maioria das cidades do mundo, o preço da passagem independe da distância percorrida, o que o torna mais simples. Na tarifa zonal, a cidade é dividida em zonas mais ou menos concêntricas com a zona central no centro e o valor da tarifa é estabelecido e função do número de zonas cruzadas na viagem. O sistema de tarifa por seções, por sua vez, é pouco utilizado. Neste sistema, as linhas são divididas por seções, sendo o valor da tarifa estabelecido em função do número de seções percorridas. Um dos problemas desses dois últimos sistemas é que o controle deve ser feito na entrada e na saída do sistema, podendo tal controle ocorrer nas estações ou nos veículos, o que exige o uso da bilhetagem eletrônica.

Numa mesma cidade, a tarifa única é mais inclusiva, uma vez que não faz discriminação entre aqueles que moram em regiões mais distantes da cidade, em geral mais pobres. No transporte metropolitano, não há necessariamente esse consenso. A Região Metropolitana de São Paulo possui diversas linhas e mais diversos são as tarifas vigentes ${ }^{66}$, que variam entre $R \$ 2,25^{67}$ a $R \$ 15,45^{68}$. Há outros serviços especiais que chegam a ter uma tarifa no valor de $\mathrm{R} \$ 36,50^{69}$. Devido à extensão da região metropolitana em questão e da variedade de tarifas, a viabilidade da adoção de uma tarifa única é de difícil equalização.

\footnotetext{
${ }^{65}$ Ferraz, Antonio Clóvis "Coca" Pinto e Torres, Isaac Guillermo Espinosa. Transporte Público Urbano. 1 ${ }^{\mathrm{a}}$ ed. São Paulo: do Autor, 2001, p. 310-311.

66 Tarifas consultadas no site da EMTU: http://www.emtu.sp.gov.br/emtu/itinerarios-e-tarifas/tarifas-emformato-pdf.fss, com vigência a partir de 01/07/2013. Site consultado em 06/01/2014.

${ }^{67}$ Tarifa referente à linha 317 de denominação Francisco Morato (Centro)-Franco da Rocha (Pq.Paulista), operada pelo Consórcio Anhanguera.

${ }^{68}$ Tarifa referente à linha (seletiva) 206 de denominação Guararema(Centro)-São Paulo(T.R.Tiete), operada pela Consórcio Unileste.

${ }^{69}$ Tarifa relativa aos ônibus que fazem a ligação São Paulo até o Aeroporto Internacional de São Paulo, localizado na cidade de Guarulhos, operados pelo Consórcio Internorte. Esses ônibus fazem parte de um serviço especial oferecido para ligar os principais pontos da cidade ao aeroporto e possuem esse custo fixo, à exceção das duas linhas que partem do metrô Tatuapé, que possuem tarifas menores, no valor de $\mathrm{R} \$ 4,45$.
} 


\section{TRANSPORTE COLETIVO METROPOLITANO}

\subsection{Introdução}

As características do transporte definem qual será a facilidade de deslocamento de pessoas, que é um fator importante na caracterização da qualidade de vida de uma sociedade e por consequência revela seu grau de desenvolvimento econômico e social. As atividades econômicas realizadas nas cidades somente serão viáveis com a utilização do sistema de transporte urbano, sendo sua estrutura e funcionamento essenciais para o desenvolvimento da cidade.

No Brasil, mais de $84 \%$ da população vive em cidades e as projeções oficiais indicam que esta concentração urbana tende a se acentuar ao longo dos anos. Em 2010, estimava-se que a população do país era de aproximadamente 190 milhões, sendo que desses 160 milhões seriam usuários do sistema de transporte urbano.

É importante ressaltar alguns conceitos que são de extrema importância para se compreender o tema de estudo. Transporte, segundo Antônio Clóvis "Coca" Pinto Ferraz e Isaac Gullermo Espinosa Torres ${ }^{70}$, é a denominação dada aos deslocamentos de pessoas e de produtos, denomina-se esse primeiro tipo de passageiros e o segundo de cargas. $\mathrm{O}$ transporte empregado no interior das cidades é denominado urbano. Para esse estudo, somente serão estudados o transporte de passageiros dentro do ambiente urbano.

O tamanho da cidade determina em grande parte o modo de locomoção de seus habitantes. Em cidades pequenas, é comum o modo de transporte a pé, enquanto que, com o aumento da cidade, a posição dos veículos particulares e taxis crescem, observando em grandes cidades a importância do transporte público, com destaque nas metrópoles do uso do metrô e de faixas exclusivas de ônibus.

\subsection{A importância do transporte público}

\footnotetext{
${ }^{70}$ Transporte Público Urbano, p. 20.
} 
O transporte coletivo é de fundamental importância nas cidades por seu aspecto social e democrático, já que representa o único modo motorizado acessível à população de baixa renda e uma alternativa àqueles que preferem não dirigir ou não podem dirigir, dentre os quais se podem destacar crianças, adolescentes, idosos e portadores de deficiência.

O papel de destaque no transporte público nas grandes cidades é a função de proporcionar uma alternativa de transporte em substituição ao automóvel, o que importa na redução da poluição atmosférica, dos congestionamentos e dos acidentes de trânsito.

É necessário destacar que o uso massivo do automóvel conduz à chamada desumanização do espaço urbano que está associado a alguns fatos, tais como a descaracterização da estrutura física das cidades devido à grande área consumida por vias expressas, obras viárias e estacionamentos, a expansão exagerada da cidade, o que dificulta as viagens a pé e por transporte público devido ao maior custo e tempo nas viagens e a mudança nos relacionamentos humanos em virtude do isolamento das pessoas no interior dos carros.

Assim, o uso massivo do carro conduz à ineficiência do espaço urbano, já que é muito maior o custo da sua infraestrutura, com a implantação e manutenção do sistema viário e da rede de serviços públicos. Além disso, o predomínio do carro e a expansão da cidade aumenta o custo do transporte, pelas grandes distâncias a serem percorridas e os congestionamentos resultantes, o que reduz a chamada economia de aglomeração ${ }^{71}$.

\subsubsection{O uso do transporte individual}

Como já identificado anteriormente, o crescimento das cidades brasileiras, ao longo das últimas décadas foi enorme. E, quanto maior forem as cidades, mais os seus habitantes dependerão das redes de infraestrutura de circulação para ter pleno acesso às oportunidades de trabalho e consumo nelas concentradas.

\footnotetext{
${ }^{71}$ Gervásio Ferreira dos Santos (Política energética e desigualdades regionais na economia brasileira. Tese (Doutorado) - Universidade de São Paulo, 2010, p. 33) apresenta a definição de economias de aglomeração: "tendência da concentração espacial da atividade econômica de criar as próprias condições econômicas que reforçam a concentração".
} 
Segundo estudo publicado em 2010 pelo IPEA, o meio de transporte mais utilizado pelos brasileiros para locomoção dentro da cidade, com pouco mais de $44 \%$, é o transporte público, sendo este, em geral, o ônibus, seguido pelo transporte por carro, $23,8 \%$, e por moto e a pé com valores similares, $12,6 \%$ e $12,3 \%$, respectivamente. Se considerarmos só a região Sudeste, o uso do automóvel é ainda maior, pouco mais que um quarto do total.

O problema está no fato de que as estruturas de circulação, ao invés de contribuírem para melhoria da qualidade de vida urbana, têm representado um fator de sua deterioração. O crescimento contínuo das cidades não é acompanhado de investimentos em infraestrutura física e operacional ou em sistemas de transporte público situados em patamares de qualidade requeridos para o bom atendimento por aqueles que necessitam se deslocar pela cidade. A falta de transporte público de qualidade estimula a expansão do uso do transporte individual, em situações em que o sistema viário é insuficiente para garantir a circulação com eficiência.

A utilização excessiva do transporte individual por veículos motorizados é um obstáculo estratégico ao crescimento econômico e uma das principais causas de deterioração da qualidade de vida urbana, na medida em que há grandes congestionamentos, conflitos entre a circulação de pedestres e veículos, condições precárias de segurança da frota, risco de acidentes, excesso de emissão de ruídos e gases, aumento dos tempos de viagem e do consumo de combustíveis.

Em geral, a solução encontrada pelo Poder Público é o investimento na expansão do sistema viário como forma de minorar os impactos resultantes dos estrangulamentos viários. Ações dessa natureza, entretanto, consolidam o espaço urbano como local de circulação, transformando-o em suporte de estruturas que viabilizam a circulação pelos bairros, sobretudo por automóveis, em detrimento de intervenções que privilegiem a transformação do espaço urbano em locais de convivência.

Uma alternativa a essa problemática encontrada nas cidades é o estímulo a outros meios de transporte, como o andar a pé ou de bicicleta, que além de saudáveis, são econômicos e não geram maior poluição. Essa solução, entretanto, é limitada, uma vez que implica geralmente em grandes distâncias a serem percorridas, já que poucos são aqueles que moram próximos ao trabalho, escola ou qualquer outro local em que há uma frequência de deslocamentos, que costumam ser localizados em regiões centrais. Isso 
também é dificultado, uma vez que o custo para se manter em lugares que possuam boa infraestrutura para os deslocamentos rápidos sugeridos (a pé e por bicicleta) são altíssimos, de forma que o estímulo de deslocamento da população para próximo de seus locais de trabalho são de difícil concretização.

Outra alternativa seria aquela da cooperação ${ }^{72}$ que pode ser inserido em cidades grandes como São Paulo, através do estímulo da carona. Insta observar que $64 \%$ dos automóveis particulares da cidade trafegam pelas ruas ocupados apenas por uma única pessoa, segundo dados da CET. Apesar dos incentivos de algumas empresas a esse sistema, as iniciativas ainda são pontuais ${ }^{73}$.

\subsection{Acessibilidade e mobilidade}

Os conceitos de acessibilidade e mobilidade, ainda que muito utilizados, não são consensuais na literatura acadêmica. Há aqueles que sustentam que os significados são iguais, enquanto que outros defendem a existência de diferenças.

De uma forma geral, pode-se definir mobilidade como um conceito que se refere à proporção de pessoas, por domicílio, classe de renda ou qualquer outro atributo, que realizam deslocamentos em um dia típico. No conceito tradicional, mobilidade é apenas a capacidade de movimentação, consideradas as condições físicas e econômicas.

Acessibilidade, por sua vez, é uma complementação do conceito de mobilidade; é a forma como uma pessoa chega a um local, isto é, a facilidade de acesso a um determinado destino. A acessibilidade, portanto, está relacionada com a efetividade do sistema de transporte em conectar localidades espacialmente separadas e a mobilidade está associada com até que ponto um determinado indivíduo pode fazer uso do sistema ${ }^{74}$.

\footnotetext{
${ }^{72}$ No artigo de Elionor Ostrom, Governing the commons, é possível inferir, pensando na problemática proposta, que a solução não está nem no público nem no privado, mas na união de ambos, já que um depende do outro. O problema da mobilidade não é uma questão exclusiva do Poder Público ou do cidadão, mas de ambos, de forma que a solução a ser encontrada deve ser apreendida e aplicada por ambos os agentes.

73 Alguns sites auxiliam o entro entre aqueles que oferecem e que necessitam de carona: www.caroneiros.com; www.caronasolidaria.com; www.ocarona.com.br; http://www.caronabrasil.com.br/; www.unicaronas.com.br; www.ecarona.com.br.

${ }^{74}$ Tal contribuição é dada por Carlos Eduardo de Paiva Cardoso em sua tese Análise do Transporte Coletivo Urbano sob a Ótica dos Riscos e Carências Sociais, p. 42.
} 
Os indicadores de acessibilidade poderiam constituir um importante componente de planejamento e modelagem de transporte, uma vez que a acessibilidade é um dos determinantes básicos da forma urbana e porque a provisão de acessibilidade é usualmente um objetivo explícito do planejamento do transporte ${ }^{75}$.

A partir desse conceito, resta analisar o que é desenvolvimento sustentável para, em seguida, estudar os medos de transporte público existentes e então partir para análise do modo objeto específico da presente dissertação.

\subsection{Modos de transporte público}

Os modos de transporte público em via terrestre, basicamente, são: metrô, trem, bonde, monotrilho, VLT, BRT e ônibus. Abaixo algumas explicações sobre eles.

\subsubsection{Metrô}

A denominação metrô é empregada para designar os trens urbanos que se movimentam em vias específicas, totalmente isoladas e com operação automatizada, o que possibilita o desenvolvimento de altas velocidades e obtenção de grandes capacidades de transporte. A energia utilizada por esse meio é a energia elétrica e as vias utilizadas, em geral, são subterrâneas, apesar de não serem incomuns trechos aéreos ou ao nível do solo.

\subsubsection{Trem suburbano}

\footnotetext{
75 Para Archimedes Azevedo Raia Júnior, (Acessibilidade e Mobilidade na estimativa de um índice de potencial de viagens utilizando redes neurais artificiais e sistemas de informações geográficas. Tese (doutorado) - Universidade de São Paulo. São Carlos, 2000, p. 13), se índices de acessibilidade significativos e sensíveis fossem disponibilizados, eles poderiam ser usados em conjunto com as relações custo e volume/capacidade na determinação da performance global de projetos de sistemas de transportes". O referido autor destaca que, além disso, em cidades maiores, há grandes diferenças na acessibilidade para diferentes grupos, para uma variedade de oportunidades econômicas e culturais e que melhores medidas de acessibilidade seriam uma ajuda em potencial para redirecionar planejamentos e políticas de forma a garantir a equalização de oportunidades entre esses grupos.
} 
O modo de transporte urbano de passageiros denominado trem suburbano refere-se ao transporte de características regionais/locais realizado nas grandes metrópoles por trens comuns utilizando os mesmos leitos do transporte ferroviário interurbano. Usualmente, a fonte de energia para a locomoção é elétrica ou diesel. A bilhetagem é realizada nas estações e o nível de automação é variado - desde sistemas ultramodernos de controle até sistemas antigos.

\subsubsection{Bonde}

Os bondes são veículos que se movimentam sobre trilhos construídos no solo e são alimentados por eletricidade, via cabos de eletricidade instalados ao longo da rota. Podem transportar mais passageiros do que um ônibus não-articulado e não poluem diretamente o meio ambiente. Apesar da ideia geral de se considerar este modo de transporte ultrapassado, veículos desse tipo com moderna tecnologia são utilizados em algumas cidades do mundo com um desempenho satisfatório, sendo que a maior parte deles se movimenta junto com o trafego normal ${ }^{76}$. Em algumas cidades, porém, as linhas de bonde atuam como atrações turísticas. Este é o caso, por exemplo, de São Francisco, Lisboa, Porto, Rio de Janeiro, Campos do Jordão e Santos.

\subsubsection{Monotrilho}

Monotrilho é uma ferrovia construída por um único trilho, em oposição às ferrovias tradicionais que possuem dois trilhos paralelos. Os monotrilhos são normalmente elevados, o que diminui o espaço ocupado, são também menos ruidosos, já que usam rodas de borracha quando em contacto com o solo, e considerados mais seguros. Comparados com os sistemas de metrô, são mais baratos e mais fáceis de construir. Mas há algumas desvantagens: os monotrilhos necessitam da sua própria via e, em caso de emergência nos monotrilhos suspenso, os passageiros não podem sair imediatamente visto não existirem plataformas para o fazerem.

\footnotetext{
${ }^{76}$ Este é o posicionamento defendido por Antonio Clóvis "Coca" Pinto Ferraz e Isaac Guillermo Espinosa Torres, in Transporte Público Urbano. $1^{\text {a }}$ ed. São Paulo: do Autor, 2001, p. 67.
} 
Na cidade de São Paulo, há a construção, pelo governo do Estado, de duas linhas de monotrilho de alta capacidade, quais sejam linha 15 Prata, que vai do Ipiranga até Cidade Tiradentes, e linha 17 Ouro, que vai do Jabaquara até Morumbi, passando ainda pelo Aeroporto de Congonhas. Há um projeto divulgado para uma terceira linha (linha 18) ligando o ABC paulista ao sistema de metro da cidade de São Paulo.

\subsubsection{VLT}

Veículo Leve sobre Trilhos (VLT), também conhecido com pré-metrô, metrô leve, é uma concepção de sistema de transporte publico situada entre o bonde e o metrô, utilizada cada vez mais na atualidade e consistente em veículos modernos sobre trilhos, normalmente operados em comboios de 2, 3 ou 4 unidades engatas e utilizando vias segregadas, ainda que seja possível em alguns trechos a operação junto ao tráfego normal, com operação automatizada e bilhetagem realizada fora dos veículos. Por partilhar alguns espaços com o restante do tráfego, a velocidade comercial do VLT é mais baixa que aqueles meios de transporte totalmente segregados, como o metrô.

\subsubsection{BRT}

O Bus Rapid Transit (BRT) é um modelo de transporte coletivo de média capacidade que visa a combinar faixas de circulação exclusivas, estações e ônibus de alta qualidade, para atingir o desempenho e qualidade observados em um sistema de metrô, com a simplicidade, flexibilidade e custo de um sistema de ônibus. Esse sistema é constituído basicamente de veículos articulados que trafegam em corredores dedicados, seja no nível do solo ou em vias elevadas.

Implementado inicialmente em Curitiba, em 1979, o BRT já é adotado em várias cidades do mundo e é considerado um meio de transporte público mais barato de construir do que um sistema sobre trilhos, com capacidade de transporte de passageiros similar à de um sistema de veículo leve sobre trilhos (VLT).

Para a operação eficiente do serviço, para que não sejam afetadas pelos congestionamentos típicos do trânsito das grandes cidades, são necessários corredores ou 
faixas exclusivas para os ônibus que podem ser elevadas, rebaixadas ou viabilizadas dentro de túneis.

Para embarque e desembarque, em geral os sistemas BRT possuem estações fechadas, onde há guichês de venda de passagem e de informação e também incluem embarque em nível, usando ônibus de piso baixo ou plataformas elevadas. Os veículos possuem múltiplas portas para acelerar embarques e desembarques e melhorar o acesso a deficientes físicos e a validação do bilhete na entrada da estação ao invés de no momento do embarque também é comum, principalmente em estações mais movimentadas.

\subsection{7. Ônibus}

Os ônibus são frequentemente o meio de transporte mais utilizado no transporte público, por constituir uma opção mais econômica que as outras existentes. Ainda, são considerados práticos e eficientes em rotas de curta e média distância, além de sua maior vantagem que é a flexibilidade. Este é o modo de transporte objeto deste trabalho.

\subsubsection{Características dos ônibus}

No mercado brasileiro, existem ônibus com diferentes características tecnológicas. Segundo Antonio Clóvis "Coca" Pinto Ferraz e Isaac Guillermo Espinosa Torres $^{77}$, os atributos mais relevantes que fazem diferença são: comprimento, suspensão, caixa de câmbio, número de portas e posição do motor.

Em relação ao comprimento, as opções são, basicamente, as seguintes: ônibus de 10 metros, ônibus de 12 metros, ônibus articulado de 18 metros e ônibus bi-articulado de 24 metros. Esta questão é importante na medida em que o comprimento interfere na quantidade de pessoas possíveis de serem transportadas.

${ }^{77}$ Transporte Público Urbano. $1^{\text {a }}$ ed. São Paulo: do Autor, 2001, p. 57-59. 
A suspensão, por sua vez, pode ser de dois tipos: com molas, que é o sistema convencional, e de ar comprimido, o que causa maior conforto aos passageiros, já que diminui os impactos verticais decorrentes de irregularidades na superfície de rolamento.

A caixa de câmbio também pode ser de dois tipos: comum, o que obriga o motorista a trocar as marchas ou automática, o que facilita o trabalho do condutor.

Em relação ao número de portas, os ônibus convencionais possuem de duas a três portas, enquanto que os ônibus articulados ou bi-articulados têm maior número de portas, a depender da necessidade de cada trajeto, já que há linhas que possuem pontos de paradas de ambos os lados do veículo, devendo, neste caso ter, no mínimo, duas portas de cada lado - uma para entrada e outra para saída de passageiros.

Já quanto à localização do motor, este pode estar próximo ao motorista, o que auxilia na refrigeração do mesmo. Isso, porém, tem suas desvantagens, já que pode dificultar a circulação dos passageiros e aumentar o calor e o ruído ao motorista e passageiros que estiverem próximos.

A capacidade dos veículos de transporte de passageiros em geral é dada pela soma do número de assentos com a quantidade de pessoas que podem viajar em pé, calculada pela multiplicação do valor da área livre disponível pelo número máximo admitido de passageiros por metro quadrado. A taxa máxima de passageiros por metro quadrado admitida varia de acordo com a qualidade imposta ao serviço de transporte. Em países desenvolvidos, as taxas adotadas variam entre 4 e 5 passageiros por metro quadrado, enquanto que em países desenvolvidos utiliza-se uma taxa aproximada de 7 passageiros por metro quadrado, sendo que em horários de pico, esse número pode aumentar para algo próximo de 12 passageiros por metro quadrado.

\subsubsection{Classificação}

O sistema regular foi regulamentado pelo Decreto $n^{\circ} 24.675 / 86$, que dispõe que as linhas podem ser classificadas basicamente como comuns e seletivas.

O serviço comum é composto por conjuntos de linhas ligando pelo menos dois municípios que fazem parte da mesma região metropolitana e são atendidos por ônibus 
urbanos comuns, com transporte de passageiros sentados e em pé. Já o serviço seletivo difere do comum uma vez que há a utilização de ônibus do tipo rodoviário, com transporte apenas de passageiros sentados.

Além do sistema regular, há o sistema fretamento regulamentado pelo Decreto $\mathrm{n}^{\mathrm{o}}$ 19.835/82. Este regime de transporte se classifica em serviço de fretamento contínuo, serviço de fretamento eventual e serviço particular com veículo próprio. Fretamento contínuo é o serviço de transporte de passageiros prestados a um cliente, mediante contrato escrito e emissão de nota fiscal, para a realização de um número determinado de viagens, com destino único e usuários definidos. Já o fretamento eventual é o serviço de transporte de passageiros a um cliente, mediante contrato escrito e emissão de nota fiscal, para a realização de apenas uma viagem, com destino único e usuários definidos. Por fim, serviço particular com veículo próprio é a atividade realizada pela empresa ou entidade no exclusivo transporte de pessoas relacionadas com sua atividade-fim, sendo que o veículo em questão deverá ser dirigido por empregado da empresa ou entidade.

\subsubsection{Corredores e Faixas Exclusivas de Ônibus}

A implantação de faixas e corredores de ônibus representa uma ação na área de trânsito $^{78}$, uma redefinição da utilização do espaço viário já existente que é disputado por uma variedade de veículos e usuários.

De acordo com a SPTRANS ${ }^{79}$, os corredores são destinados à circulação exclusiva para ônibus de grande porte e foram criados para distribuir melhor os veículos nas vias, diminuindo o trânsito. Os corredores, em geral, possuem paradas maiores e são instalados em faixas do lado esquerdo da pista, onde não há compartilhamento com veículos que farão conversão nos cruzamentos. Nesses corredores, ainda vigora o compartilhamento com taxis a qualquer horário, desde que o veículo esteja com passageiros e o veículo não disponha de película escura nos vidros ${ }^{80}$. Há ainda o

\footnotetext{
${ }^{78}$ Vide Vasconcellos, Eduardo Alcântara, Circular é preciso, viver não é preciso.A história do trânsito na cidade de São Paulo. São Paulo: Annablume/Fapesp, 1999, p. 149

${ }^{79}$ http://www.sptrans.com.br/terminais/, acessado em 13/01/2014.

${ }^{80} \mathrm{Na}$ cidade de São Paulo, há um estudo divulgado em dezembro de 2013 no qual a Prefeitura de São Paulo concluiu que apenas os ônibus devem circular nos corredores da cidade e que a presença dos táxis prejudica a
} 
compartilhamento da via com viaturas policiais, ambulâncias, bombeiros, viaturas de manutenção e fiscalização do sistema de transporte. Há a possibilidade de circulação de veículos de passeio em horários específicos: das $23 \mathrm{~h}$ às $4 \mathrm{~h}$ durante os dias úteis, das $15 \mathrm{~h}$ de sábado até as $4 \mathrm{~h}$ de segunda e das $0 \mathrm{~h}$ às $4 \mathrm{~h}$ durante os feriados.

Faixas exclusivas são localizadas à direita das vias e fazem parte da "Operação Dá Licença para o Ônibus", que tem como objetivo aumentar a fluidez do transporte coletivo na cidade. O período e horários de ativação da faixa exclusiva variam de acordo com cada local e é regulamentado com placas instaladas ao longo de cada trecho. A circulação de veículos nessa faixa é permitida para acesso a garagens e conversões a direita para a outra via, neste caso somente no trecho com pintura de faixa tracejada. Nessas faixas, não é possível o tráfego de taxistas.

Na cidade de São Paulo, a multa para quem circular indevidamente nos corredores são de $\mathrm{R} \$ 127,69$ com cinco pontos na carteira e de $\mathrm{R} \$ 53,20$ e mais três pontos na carteira para aqueles que trafegarem fora dos horários permitidos nas faixas exclusivas.

velocidade dos coletivos. Este estudo foi encomendado pelo Ministério Público do Estado e pode apontar para possível ação judicial para a restrição da circulação de taxis nos corredores de ônibus. Tal notícia foi divulgada na mídia: http:/g1.globo.com/sao-paulo/noticia/2013/12/prefeitura-conclui-em-estudo-que-soonibus-devem-usar-corredores-em-sp.html, acessado em 12/01/2014. 


\section{DELEGAÇÃO DE SERVIÇOS DE TRANSPORTE NA RMSP}

A Região Metropolitana de São Paulo foi dividida em cinco áreas de operação, somados à capital paulista, para a concessão dos serviços intermunicipais metropolitanos. O município de São Paulo, por sua função central, torna-se uma área comum a todas as áreas de concessão. Além dessas 5 áreas, há o Corredor Metropolitano $\mathrm{ABD}^{81}$, que liga o bairro de São Mateus, no extremo leste paulista, ao Jabaquara, bairro da zona sual, passando por quatro municípios da RMSP: Mauá, Santo André, São Bernardo do Campo e Diadema. O referido corredor, com extensão de 33 quilômetros, é exclusivo para ônibus e trólebus e é gerenciado pela EMTU/SP. Esse corredor é operado pela empresa concessionária METRA desde 1997 e possui contrato de concessão por vinte anos.

Quanto à composição de municípios, a Área 1 é composta pelos municípios de Juquitiba, São Lourenço da Serra, Embu-Guaçu, Itapecerica da Serra, Embu, Taboão da Serra, Vargem Grande Paulista e Cotia que ocupam território 1.500 km², sendo $1.217 \mathrm{~km}^{2}$ dentro de área de proteção de mananciais. A Área 2, por sua vez, é composta pelos municípios de Cajamar, Caieiras, Itapevi, Jandira, Carapicuíba, Osasco, Barueri, Santana de Parnaíba, Pirapora do Bom Jesus, Francisco Morato e Franco da Rocha, ocupando uma superfície de $968 \mathrm{~km}^{2}$ e desse total $140 \mathrm{~km}^{2}$ estão em área de proteção de mananciais. Já a Área 3 é composta pelos municípios Guarulhos, Arujá, Mairiporã e Santa Isabel que ocupam território de $1.098 \mathrm{~km}^{2}$, sendo $690 \mathrm{~km}$ em região de proteção de mananciais. Por sua vez, a Área 4 é composta pelos municípios de Ferraz de Vasconcelos, Itaquaquecetuba, Poá, Mogi das Cruzes, Guararema, Biritiba Mirim, Salesópolis e Suzano que ocupam território $2.135 \mathrm{~km}^{2}$, sendo $152,14 \mathrm{~km}^{2}$ de área urbanizada e $1.280 \mathrm{~km}^{2} \mathrm{em}$ área de proteção de manancial. Por fim, a Área 5 é composta pelos municípios de Diadema, São Caetano do Sul, São Bernardo do Campo, Santo André, Mauá, Ribeirão Pires e Rio Grande da Serra, distribuídos em área de $841 \mathrm{~km}^{2}$, sendo $472 \mathrm{~km}^{2}$ dentro da área de proteção de mananciais e $290.14 \mathrm{~km}^{2}$ em área urbanizada.

Diante desse quadro, cabe ressaltar qual é o papel da EMTU (Empresa Metropolitana de Transportes Urbanos) nas regiões metropolitanas. A EMTU é uma

\footnotetext{
${ }^{81}$ Optou-se por não analisar em profundidade o referido Corredor, já que sua estrutura e funcionamento se assemelham à do metrô, com a utilização de veículos elétricos, e índices de qualidade superiores ao transporte coletivo por ônibus típico.
} 
sociedade de economia mista que é responsável pelo planejamento, gerenciamento, fiscalização e controle dos sistemas de média e baixa capacidades nas Regiões Metropolitanas do Estado de São Paulo. A empresa é controlada pelo Governo do Estado de São Paulo, vinculada à Secretaria de Estado dos Transportes Metropolitanos (STM). Esta empresa é a responsável pela realização das licitações, gerenciamento e fiscalização dos contratos realizados.

A divisão em regiões foi pensada para que houvesse licitação e contratos de concessão de forma dividida, não mais baseados em cada linha de transporte definidos, como era antes feito. Desta forma, há mais organização e possibilidade de fiscalização das empresas responsáveis pela prestação do serviço. Se a licitação se baseasse em uma ou algumas linhas, haveria a possibilidade de determinadas localidades, em que não há tanta lucratividade aparente, não haver licitantes para contratação.

Isso, porém, não se alterou por completo com a criação das regiões, já que as licitações para a Área 5 não obtiveram qualquer resultado até a presente data. Isso seria justificado, possivelmente, pelas incertezas do setor em relação a uma série de projetos em outros modais para a região, como a Linha 18-Bronze, por meio do Metrô Leve, o que pode ter levado a uma desconfiança sobre possível migração de passageiros dos ônibus para o veículo de trilho.

As áreas 1, 2, 3 e 4 foram licitadas num mesmo período, entre os anos 2005 e 2006, e possuem contratos bastante semelhantes. Optou-se, para fins acadêmicos, analisar somente o procedimento licitatório da área 1 a fim de estabelecer quais os elementos essenciais para a contratação no setor de transporte coletivo metropolitano.

Antes, porém, cabe fazer algumas observações acerca de alguns elementos presentes na licitação, imprescindíveis para melhor entendimento da matéria.

\subsection{Elementos iniciais}

Para compreender melhor o que será discutido no contrato analisado, é necessário verificar alguns pontos que está no contrato, mas independe dele, uma vez que existia anteriormente. 


\subsubsection{PAESE}

Em razão do transporte coletivo ser imprescindível para garantir a locomoção dos usuários do sistema metropolitano, exige-se a elaboração e implementação de esquemas de atendimento às situações de emergência. No contrato analisado há a previsão desse serviço.

No Decreto Estadual $n^{\circ} 40.781 / 96^{82}$, que dispõe sobre o regulamento para concessão do serviço de transporte intermunicipal por ônibus e trólebus no Corredor Metropolitano São Mateus/Jabaquara, há a disposição de que é um dever da Concessionária elaborar e implementar esses esquemas, mantendo disponíveis, para tanto, recursos humanos e materiais. A partir de então foram exigidas essas providências em conjunto de todas as concessionárias.

Como o sistema de transporte coletivo é interligado e que eventuais problemas em qualquer sistema repercuta sobre os demais, somente a atuação coordenada entre os concessionários, junto com os demais vetores de transporte pode minimizar os transtornos em situações de emergência.

Para essa atuação coordenada para situações extraordinária foi firmado o convênio chamado PAESE - Plano de Apoio entre Empresas de Transporte frente a Situações de Emergência entre as empresas EMTU, CPTM, METRÔ e SPTRANS, com a finalidade de atender aos usuários dos sistemas de transporte coletivo quando houver paralisação em qualquer um deles, seja qual a ocorrência que origine tal quebra de serviço.

O valor de remuneração do PAESE é determinado pela Secretaria de Transportes Metropolitanos ${ }^{83}$ e seu acionamento será realizado com a convocação das concessionárias mais próximas da intervenção operacional

\subsubsection{ORCA e Reserva Técnica Operacional}

\footnotetext{
${ }^{82}$ Artigo 10, inciso IX, mais precisamente.

${ }^{83}$ Verifica-se o custo por hora e veículo utilizado.
} 
A fim de coibir o transporte público clandestino, a Secretaria de Transportes Metropolitanos - STM realizou estudos sobre os transportadores informais não autorizados, considerando além do exame da questão do ponto de vista eminentemente técnico, suas implicações no equilíbrio econômico-financeiro dos serviços de transporte, do controle operacional e do seu impacto nos sistemas viários municipais e metropolitanos. A partir disso, foi criado o serviço ORCA - Operador Regional de Coletivo Autônomo em agosto de 1999 por meio da Resolução STM n 37 , de 24/08/99 ${ }^{84}$, consolidado na Resolução STM $n^{\circ} 80$, de 08 de dezembro de 2006 e posteriormente revisado na Resolução STM n 95 , de 31 de outubro 2011. Em 2005, o número de veículos e operadores autônomos correspondia a $644^{85}$.

Com o advento da concessão das áreas de operação da Região Metropolitana de São Paulo, em 2006, o sistema ORCA foi modificado para RTO - Reserva Técnica Operacional $^{8687}$. A justificativa para a manutenção desses operadores é que eles seriam o efetivo que o Estado poderia utilizar em caso de emergências que diminuam a oferta do serviço de transporte, já que sem tal recurso o Governo do Estado deve recorrer às prefeituras e às empresas operadoras privadas.

Nos referidos textos normativos, há a previsão da contratação de empresas individuais, que só teriam autorização para operar um único veículo ${ }^{88}$, que seria de pequeno porte, para realizar serviços especiais ou complementares em linhas do sistema

\footnotetext{
${ }^{84}$ Esse serviço já havia sido previsto no artigo $9^{\circ}$, parágrafo $1^{\circ}$, do Decreto $n^{\circ} 24.675$, de 30 de janeiro de 1986.

${ }^{85}$ Esta informação está no anexo referente à Reserva Técnica Operacional, do Edital de concessão da Área 1.

${ }^{86}$ A troca da nomenclatura está expressa no anexo referente à Reserva Técnica Operacional no edital de concessão da Área 1 estudado.

87 Os contratos das empresas individuais foram mantidos, ainda que houvesse a previsão de que as autorizações seriam canceladas com a concessão das linhas da Região Metropolitana de São Paulo, sem que isso gerasse qualquer indenização aos operadores. Essa previsão está contida no artigo 14, parágrafo único, da Resolução STM no 37/99, mantida, inclusive no artigo 12, parágrafo único, da Resolução STM nº 80/2006 e também consta na Resolução STM no 95/2011. No curso dos anos, alguns dos operadores deixaram de prestar o serviço, mas não há previsão oficial para contratação de novas empresas para o serviço na RMSP, já que é necessária nova seleção de operadores, na forma prevista pela legislação. Esta decisão da manutenção dos contratos foi uma decisão política, já que o Governo do Estado necessitava ter uma frota "própria" e não tinha condições para tanto - esse é, inclusive, o discurso oficial apresentado no anexo do edital da Área 1 analisado -, e a pressão política das empresas individuais integrantes do ORCA, que perderiam seus empregos com a extinção total da categoria. Essa pressão se deu, inclusive, na audiência pública para a concessão do serviço de transporte na Região Metropolitana de São Paulo, com o comparecimento de vários condutores.

${ }^{88}$ No artigo $8^{\circ}$, parágrafo $3^{\circ}$, da Resolução STM nº 80/2006, há a previsão de que dois operadores, com personalidades jurídicas distintas, operem um único veículo cadastrado, mediante autorização da EMTU.
} 
regular, em linhas de conexão entre sistemas de transportes do Estado, denominadas "Ponte ORCA", e em linhas de Serviço Especial Conveniado - SEC, que permitem a inserção no sistema de transporte metropolitano das pessoas com deficiência ou de mobilidade reduzida severa, impossibilitadas de utilizarem o transporte regular, em atendimento aos programas específicos do Governo, vinculados às áreas de educação, saúde, cultura e lazer.

O número total de contratados a título de ORCA não pode ultrapassar a percentagem de $20 \%$ do total da frota metropolitana ou de cada área metropolitana específica e são distribuídos proporcionalmente a cada região, de modo equivalente à frota das empresas operadoras em cada área.

Cabe à EMTU a gestão, incluindo a elaboração de estudos técnicos, a organização, a vistoria e o controle dos veículos utilizados nos serviços especiais integrados por ORCA's e RTO's. A idade máxima de cada veículo é 7 (sete) anos para os serviços regulares, enquanto os que estiverem alocados no Serviço Especial Conveniado SEC poderão ter idade máxima de 8 (oito) anos, contados do primeiro emplacamento ou da nota fiscal de compra do veículo zero.

Os operadores são obrigados a manter suas informações atualizadas, apresentando anualmente documentação para registro cadastral na Secretaria de Transportes Metropolitanos, sem o qual se inabilitam à prestação do serviço, bem como devem apresentar os seus veículos para vistorias semestrais obrigatórias. Com a apresentação de todos os documentos exigidos, bem como com a vistoria dos veículos, é expedido para cada operador o CRO - Certificado de Registro de Operação, expedido pela EMTU, que é intransferível, bem como o selo de vistoria expedido pela EMTU.

A contratação dos operadores se dá com a efetiva comprovação de regular inscrição no cadastro de pessoas jurídicas e a apresentação das apólices quitadas do seguro obrigatório e do seguro para cobertura de danos materiais, morais, responsabilidade civil e acidente pessoais de passageiros e contra terceiros.

Os veículos dos ORCA's deverão ser caracterizados no padrão visual metropolitano, conforme padronização definida e disponibilizada pela EMTU 


\subsection{3. Índice de Qualidade do Transporte - IQT}

A gestão dos serviços de transporte, com o tempo, exigiu a adoção de uma ferramenta para a monitoração do desempenho das permissionárias e atuação sobre suas eventuais falhas e desvios durante a execução do contrato. Com vistas a esta questão, a EMTU/SP, no seu papel de gestora do transporte público intermunicipal, desenvolveu, ao longo dos anos, uma forma de avaliação da qualidade dos serviços de transporte, baseada em indicadores de desempenho. Há no contrato analisado um anexo somente sobre esse tema, visto a importância que se dá a este índice.

O objetivo do Índice de Qualidade do Transporte - IQT é estabelecer um instrumento de avaliação do desempenho do Transporte Coletivo Regular de Passageiros baseado em indicadores de gestão que propicie meios para o controle do padrão dos serviços prestados pela permissionária.

O Sistema de Avaliação é composto por índices parciais de avaliação dos seguintes aspectos: frota (IQT), obtido a partir dos resultados das inspeções veiculares realizadas pela fiscalização da EMTU, operação (IQO), obtido a partir dos resultados das fiscalizações operacionais realizadas pela fiscalização da EMTU, desempenho EconômicoFinanceiro (IQE), obtido a partir dos demonstrativos contábeis e econômico-financeiros apresentado pela permissionária, e satisfação do cliente (IQC), obtido a partir de pesquisas de campo realizadas pela equipe da EMTU.

Cada índice é obtido e calculado isoladamente e suas respectivas pontuações serão expressas em números decimais variando entre zero e dez. O Índice de Qualidade do Transporte - IQT é obtido mediante a seguinte fórmula:

$$
\mathrm{IQT}=0,25 . \mathrm{IQF}+030 . \mathrm{IQO}+0,30 . \mathrm{IQC}+0,15 . \mathrm{IQE}
$$

O que se observa de tal fórmula é que há um grande peso em dois fatores: a opinião do cliente e a questão operacional. Esta última é medida a partir de um controle das infrações cometidas pela permissionária e verificadas pelas fiscalizações realizadas durante a prestação dos serviços e se dividem em operação das linhas - que se relacionam aos aspectos operacionais dos serviços prestados - e veículos em operação - que se 
relacionam às falhas observadas nos veículos durante a prestação dos serviços ${ }^{89}$. Assim, pode-se concluir que o peso maior para o índice do transporte está na prestação final do serviço, já que leva em conta a operação em si e a opinião daqueles que utilizam o serviço.

Importante destacar que há a necessidade das empresas permissionárias atingirem um mínimo que é uma nota mínima de suficiência para cada um dos índices parciais ou do IQT. Caso algum desses índices não cumpra essa exigência, há a necessidade da permissionária fazer um programa de recuperação de desempenho para o próximo ciclo de avaliação do IQT. Nesse sentido, há uma vinculação do serviço a uma qualidade considerada mínima ou satisfatória que permite um nivelamento do serviço e, para as melhores qualificadas no IQT, há a previsão de possível prêmio oferecido pela EMTU. Há, porém, a previsão do caso de possível insuficiência contumaz, no qual a permissionária que obter pontuação insuficiente em um ou mais dos índices do IQT em dois ciclos seguidos ou em quatro ciclos alternados poderá ser penalizada pela EMTU, que poderá, inclusive, exigir um programa de recuperação assistida.

\subsubsection{Projeto METROPASS}

Este projeto é anterior à concessão que será analisada, na qual prevê a formação de consórcio pelas concessionárias de todas as áreas para administração do sistema de bilhetagem eletrônica.

O METROPASS foi instituído e regulamentado pelos Decretos estaduais $n^{\circ}$ 43.680/98 e 49.081/04 e resoluções da Secretaria de Transportes Metropolitanos o Sistema METROPASS, que prevê o processo de pagamento de tarifas de viagens e de acesso aos sistemas metroviário, ferroviário, de ônibus e trólebus por meio de cartões inteligentes com créditos armazenados na forma de valores monetários, direitos de viagens ou passes temporários.

\footnotetext{
${ }^{89}$ Nesse ponto, cabe destacar que as falhas observadas na fiscalização operacional distinguem-se das falhas observadas quando da fiscalização da frota, já que estas se relacionam ao estado geral do veículo, constatadas em inspeções veiculares realizadas nas garagens da permissionária, enquanto que as falhas observadas na fiscalização que repercutem no índice de qualidade operacional são observadas nos veículos durante a operação dos serviços.
} 
A implantação desse sistema se deu inicialmente nos sistemas estruturais de metrô e trem metropolitano, expandindo depois para o Corredor metropolitano de Trólebus São Mateus/Jabaquara (Corredor ABD) e nas linhas de ônibus intermunicipais.

Previa-se a implantação desde sistema na Região Metropolitana de São Paulo, sendo estendida após, com o Decreto $n^{\circ}$ 48.668/04, para as demais Regiões Metropolitanas do Estado de São Paulo. Houve a autorização para licitação com o Decreto no 48.669/04 e, depois, a regulamentação da concessão do sistema com o decreto $\mathrm{n}^{\circ} 49.081 / 04$, sendo que a licitação a ser realizada é do tipo concorrência internacional e a receita da concessionária uma porcentagem da receita tarifária, além de outras receitas provenientes da exploração da atividade, tais como receita pela expedição de cartões e exploração de publicidade.

É previsto no regulamento que a concessionária responsável pelo sistema deverá realizar a emissão de cartões eletrônicos, a distribuição de cartões eletrônicos e carregamento dos cartões com créditos em valores monetários, direitos de viagem e passes temporários, cobrança e arrecadação de tarifas e controle de acesso dos usuários do sistema metropolitano de transportes públicos de passageiros, processamento e liquidação das transações financeiras do sistema, além de outros serviços que vierem a ser agregados. Nesse sentido, a emissão, distribuição e venda de bilhetes tipo Edmonson ou outros tipos de direitos de viagem também devem ser realizadas, de forma que não há o total abandono do bilhete de papel.

\subsubsection{Bilhete do Ônibus Metropolitano - BOM}

O BOM é o cartão eletrônico de transporte idealizado pelo projeto e criado a partir de um consórcio de todas as empresas que o utilizam: os quatro consórcios responsáveis pelas áreas 1 a 4 e as 16 empresas que operam as linhas da área 5.

O citado bilhete pode ser utilizado em 39 municípios da Região Metropolitana de São Paulo, no corredor São Mateus/Jabaquara e em sua extensão Diadema/Berrini, no sistema metro ferroviário (Metrô e CPTM) e nas linhas municipais dos municípios de Carapicuíba, Cotia, Ferraz de Vasconcelos, Mairiporã, Poá, Ribeirão Pires, Rio Grande da Serra, São Caetano do Sul, Suzano e Taboão da Serra. 


\subsubsection{Gratuidades}

O sistema de transporte se sujeita a algumas restrições na exigência do pagamento da tarifa devida pelo usuário. Tais restrições, porém, advém de uma série de textos normativos, sejam eles federais ou estaduais, os quais são importantes para o estudo e se descreve a seguir.

A cobrança de alunos e professores de estabelecimentos de ensinos oficiais, oficializados e reconhecidos deve ser feita com desconto de $50 \%$ no preço das tarifas, conforme o disposto no artigo 34 do Decreto Estadual n. ${ }^{\circ} 24.675$, de 30 de janeiro de 1986.

Há isenção no pagamento de tarifa nos seguintes casos, previstos no artigo 35 do Decreto Estadual n. ${ }^{\circ}$ 24.675, de 30 de janeiro de 1986, modificado pelo Decreto n. ${ }^{\circ}$ 27.436, de 7 de outubro de 1987: a) Membros da Comissão de Transportes; b) Agentes designados para a fiscalização dos serviços; c) Integrantes uniformizados das Guardas Civis Metropolitanas; d) Menores de até 5 (cinco) anos de idade, desde que não ocupem assentos. Acrescido a isso, a Resolução SNM n. ${ }^{\circ}$ 33, de 28 de fevereiro de 1985, autoriza o transporte gratuito aos policiais militares, desde que fardados e de posse de identificação funcional. A fim de regularizar esta questão por meio de lei estadual, foi promulgada a Lei Estadual $\mathrm{n}^{\circ} 10.380$, de 24 de setembro de 1999. Contra esta lei, entretanto, foi proposta ação direta de inconstitucionalidade de lei estadual $n^{\circ}$ 9028232-93.2005.8.26.0000, que foi julgada procedente e contra a qual foi interposto recurso extraordinário ( $\mathrm{n}^{\circ} 592612$ ) ao qual foi negado seguimento. $\mathrm{O}$ argumento principal para que a lei fosse considerada inconstitucional foi o fato de que haveria reserva ao governador da iniciativa legislativa referente ao tema das concessões e permissões de serviço público, previsto na Constituição Estadual no artigo 47, inciso XVIII, e no caso em questão a iniciativa foi da deputada Edna Macedo. Já houve o trânsito em julgado da questão em 03 de outubro de 2010. Desta forma, a gratuidade do transporte dos policiais militares fardados está baseada numa resolução antiga cuja vigência e obrigatoriedade poderiam ser questionadas.

Em relação aos maiores de sessenta e cinco anos, a gratuidade do transporte coletivo por ônibus, desde que de característica comum, está prevista no parágrafo segundo do artigo 230 da Constituição Federal e na Resolução STM n. ${ }^{o}$ 200, de 4 de março de 
1993. Já as pessoas portadoras de deficiências, está garantida a isenção do pagamento de tarifas de transporte coletivo regular pelos seguintes dispositivos: artigo $1^{\circ}$ da Lei Complementar Estadual n. ${ }^{\circ}$ 666, de 26 de novembro de 1991, regulamentada pelo Decreto Estadual n. ${ }^{\circ}$ 34.753, de 1 de abril de 1992, e Resolução Conjunta SS/STM n. ${ }^{\circ}$ 3, de 2004, alterada pelas Resoluções Conjuntas n. ${ }^{\circ}$ 4, de 22 de dezembro de 2004, n. ${ }^{\circ}$, de 4 de janeiro de 2006, e n. ${ }^{\circ} 6$, de 27 de setembro de 2006. Neste ponto, cabe ressaltar que para os maiores de sessenta e cinco anos, a apresentação de documento de identidade é suficiente para a isenção em questão, enquanto que para os portadores de deficiência, há a necessidade de laudo pericial que comprove a incapacidade para o trabalho, na forma da legislação supra.

Pelo artigo 13 do Decreto-Lei Federal n. ${ }^{\circ}$ 9.797, de 9 de setembro de 1946, e o artigo 43 da Lei Federal n 5.010, de 30 de maio de 1966, há a isenção para os oficiais de diligência da Justiça do Trabalho e da Justiça Federal. Da mesma forma, os agentes de inspeção do Trabalho, em conformidade com o artigo 630 da Consolidação das Leis do Trabalho - CLT e os Carteiros e Mensageiros da Empresa Brasileira de Correios e Telégrafos - ECT, de acordo com o artigo $9^{\circ}$ do Decreto Lei Federal n. ${ }^{\circ} 3.326$, de 3 de junho de 1941, e artigo 51 do Decreto Lei Federal n. ${ }^{\circ}$ 5.405, de 13 de abril de 1943, são igualmente isentos. Cabe destacar que essas isenções foram dadas pela esfera federal mas o custo disso é revertido ao Estado, no caso do transporte metropolitano. Outro ponto importante a se ressaltar é a idade dos textos normativos que impõe essa restrição, que são em demasia antigos e naquele momento histórico talvez se fizesse necessário. $\mathrm{Na}$ atualidade, porém, essa isenção não parece mais necessária. Há a possibilidade de convênios entre as empresas de transporte e os entes públicos que torne menos oneroso para o Estado, no caso.

Por fim, há a gratuidade aos desempregados, que é instituída pelo Secretario de Transportes Metropolitanos, de acordo com o Decreto $\mathrm{n}^{\circ}$ 32.144/90. Atualmente exclusivamente no corredor São Mateus/Jabaquara conta com tal benefício, o que é realizado mediante comprovação de que anteriormente trabalhava com carteira assinada por mais de seis meses em alguma empresa da região do corredor, válido por somente 28 dias. 
A depender do contrato realizado, o benefício da gratuidade compõe o valor da tarifa como custo, que é arcado pelos demais usuários pagantes do serviço de transporte público local.

No contrato que será analisado, entretanto, não há essa previsão, já que a remuneração do concessionário se dá somente com a tarifa paga pelos usuários, sem previsão de contraprestação ou de pagamento por usuário do sistema no sistema de transporte. Isso não acontece, por exemplo, na minuta de edital que a Prefeitura de São Paulo divulgou, no qual o pagamento dos concessionário se daria pela quantidade de usuários transportados, independente de serem pagantes ou não.

\subsubsection{Integração}

A integração no transporte de passageiros pode ser física, tarifária e sincronizada. A primeira se dá quando duas ou mais linhas de transporte público passam pelo mesmo local, permitindo a realização de troca de veículos, em geral sem grandes distâncias a serem percorridas a pé.

Já a integração tarifária está associada à desnecessidade dos usuários pagarem novamente para fazer transbordo, uma ou mais vezes, entre veículos de linhas distintas ou pagarem um valor adicional significativamente menor do que o preço normal das duas passagens que teriam que pagar para completar a viagem. Este sistema busca, acima de tudo, garantir o acesso ao sistema de transporte público, já que elimina discriminações geográficas, garantindo ao usuário que necessita percorrer grandes distâncias e que poderia necessitar de mais de uma condução para o destino final que não pague além de uma única tarifa. Além disso, há uma clara democratização do espaço urbano, uma vez que o deslocamento entre vários pontos da cidade auxilia o aumento nas oportunidades de trabalho e estudo, por exemplo.

Por fim, a integração tarifária tem duas vertentes: a integração tarifária pelo uso de terminais ou de bilhetes e cartões. No caso da integração tarifária pelo uso de terminais, há alguns pontos negativos como o custo para desapropriação de grandes áreas para a integração, além dos custos para sua construção e manutenção. Ainda, tal sistema pode gerar um agravamento de problemas de trânsito ao redor dos terminais. Como 
benefícios, os terminais proporcionam maior conforto e segurança nas operações de embarque e desembarque, racionalização da rede de linhas e da programação operacional. Um ponto relevante é a questão da facilidade na fiscalização do cumprimento de horários e uma melhoria nas necessárias correções de problemas operacionais.

Por outro lado, a integração tarifária com o emprego de bilhetes ou cartões apresenta, em relação aos terminais, menor custo e permite ao usuário um maior número de opções de locais de transbordo, com a consequente redução do tempo de viagem para parte dos usuários. Isso resulta, entretanto, em menor conforto nas operações de transferência, já que os pontos não possuem a mesma estrutura dos terminais, e maior dificuldade no controle da operação e na correção de atrasos e defeitos de veículos. Em relação a esses dois problemas operacionais, porém, há a alternativa do uso da tecnologia de rastreamento de veículos, que permite o acompanhamento em tempo real do trajeto, paradas e apresentação de eventuais defeitos nos veículos.

De uma forma geral, as duas formas de integração tarifária podem ser complementares uma a outra, ainda que se possa escolher uma em detrimento da outra. Terminais urbanos ou metropolitanos são de extrema importância e a escolha de fechá-los para realizar a integração, ainda que seja custoso, pode ser realizado.

Vale lembrar que as estruturas físicas terminais metropolitanos são essenciais para o desenvolvimento da ideia do sistema, já que uma rede metropolitana não deve fazer o papel do transporte municipal de usuários. Desta forma, a concentração da demanda em terminais facilita a realização do transporte.

\subsection{Análise do procedimento licitatório da Área 1}

O estudo do procedimento em questão foi dividido da seguinte forma para melhor compreensão da questão: análise da audiência pública realizada para o procedimento, verificação do edital, compreensão das intervenções realizadas pelo Tribunal de Contas, análise do Compromisso de Constituição de Consórcio realizado pelas empresas a fim de participar do certame, verificação da avaliação da proposta apresentada para o edital, análise dos principais pontos de Ação Civil Pública interposta para paralisação do procedimento e, por fim, análise do contrato realizado. 


\subsubsection{Audiência Pública ${ }^{90}$}

As licitações 1, 2, 3 e 4 tiveram audiência pública comum no dia 16/02/2005, na qual se estabeleceram as diretrizes para o procedimento. Durante as apresentações iniciais, foi dado um bom panorama da situação naquele momento do transporte metropolitano de São Paulo. Basicamente o transporte era realizado por diversas empresas que detinham a permissão de exploração de determinadas linhas, de forma que havia 52 empresas atuando na Região, num total de 511 linhas existentes então.

A ideia passada na audiência seria de que haveria uma divisão da Região Metropolitana de São Paulo em quatro, cinco ou seis áreas, sendo que em cada uma dessas seria realizada uma licitação diferente para que uma empresa, ou várias empresas em consórcio, obtivesse a permissão para explorar o serviço de transporte na forma previamente imposta pelo Poder Público; haveria, por imposição prévia, a necessidade da manutenção das linhas existentes. Isso, entretanto, não significaria que mudanças não seriam realizadas ao longo do contrato. Com a realização de quatro, cinco ou seis contratos, a Administração teria melhores condições de planejar e otimizar, em conjunto com as empresas permissionárias, o serviço prestado, diminuindo drasticamente a quantidade de interlocutores. Inclusive, seria do próprio interesse das empresas permissionárias a inclusão, modificação e eventual exclusão de linhas para melhoria do serviço prestado, já que tais acontecimentos seriam analisados pelo Poder Público, e necessitariam de autorização deste, e em caso de algum desgaste financeiro para o permissionário isso poderia ser revisto no contrato assinado. A contratação por Áreas permite que a Administração possa de fato planejar o transporte metropolitano, antes dificultada pela existência de contratos por linhas. Para não haver problemas entre as empresas permissionárias das áreas constituídas, a EMTU atuaria na organização das linhas intersetoriais e interáreas.

Na audiência pública se enfatizou também que a licitação e o contrato de permissão estariam delineados em leis e decretos federais e estaduais. Houve a explanação

\footnotetext{
${ }^{90} \mathrm{O}$ documento que embasa o presente subcapítulo é denominado Transcrição da Fala da Audiência Pública realizada em 16/02/2005, Referente à Concessão do Transporte Intermunicipal de Passageiros na RMSP e está disponível no procedimento licitatório referente à Área 1 estudada.
} 
breve de que a lei estadual nº 7835/92 dá autorização para o governador fazer licitações de concessão e permissão de serviço público e que o regulamento para tanto está nos decretos $n^{\circ} 42.858$ e 42.859/98, alterados pelo decreto $n^{\circ} 49.303 / 04$, para constar o prazo máximo de 10 anos para a concessão, sendo que da assinatura do contrato o concessionário deverá iniciar suas operações no prazo máximo de 180 dias.

Foi introduzida na reunião a ideia de que seria necessária a junção das empresas ou consórcios vitoriosos num novo consórcio que teria a função de administrar a cobrança de bilhetagem eletrônica, cujas atividades o Poder Público teria acesso irrestrito.

Não haveria na licitação em questão a necessidade das empresas permissionárias realizarem obras ou implementarem pontos de parada, abrigos ou terminais. Isso foi enfatizado na reunião uma vez que a licitação anterior, realizada em 1997, na qual foi objeto o corretor São Mateus-Jabaquara, essas questões eram objeto do contrato.

Foi discutida também a previsão de um Grupo de Gestão de Transporte Intermunicipal Metropolitano (GETIM), que seria um grupo paritário para resolver questões entre os permissionários e o Poder Concedente, numa tentativa de conciliação antes de eventual discussão judicial.

Ao final, feitas as perguntas, verificou-se a preocupação na extinção do cargo do cobrador dentro dos ônibus metropolitanos, ao que foi respondido que não haveria a extinção do cargo, que somente os ônibus seletivos poderiam, pelas condições de trabalho, não ter tal profissional. À época houve a assinatura de termo de compromisso pela EMTU com o Ministério Público de São Bernardo do Campo para que os microônibus tivessem cobradores ou sistema de bilhetagem eletrônica para que não houvesse a execução de dupla função pelo motorista, que fazia as vezes de cobrador, e poderia prejudicar a realização de sua função primeira que é dirigir com atenção e responsabilidade. O compromisso, assumido para a cidade de São Bernardo do Campo, foi estendido para toda a Região Metropolitana de São Paulo ${ }^{91}$.

\footnotetext{
${ }^{91}$ Deve-se ressaltar que o Ministério Público também propôs às empresas responsáveis pelo transporte no município de São Bernardo do Campo a possibilidade de assinatura de termo de compromisso de ajustamento de conduta, o que foi negado devido ao fato dos responsáveis pelo transporte municipal entenderem necessário um prazo superior ao oferecido, de 30 meses, para a adequação do sistema. Devido a isso, foi proposta ação civil pública, que tramitou perante a $3^{\mathrm{a}}$ Vara Cível de São Bernardo do Campo sob o $\mathrm{n}^{\mathrm{o}}$ 0012767-57.2005.8.26.0564, que culminou com uma determinação judicial para a adequação dos veículos, ônibus e microônibus, e extinção do exercício da dupla função dos motoristas. Atualmente o processo está
} 
Interessante notar que uma das perguntas direcionadas à mesa na audiência perguntou sobre eventual convênio das prefeituras com a EMTU para fiscalização dos ônibus dentro de seus perímetros. Na resposta constou que há alguns convênios, que o auxílio na fiscalização é bem vindo, sendo que podem ser disponibilizados documentos que informem a tabela de horários dos ônibus e seus itinerários. Foi também colocado que em Santos quem realiza o serviço de fiscalização é o Ministério Público.

\subsubsection{Edital}

Como foi discutido anteriormente, ficou decidido a divisão da Região Metropolitana de São Paulo em cinco áreas. $\mathrm{O}$ edital estudado diz respeito à área 1 , que compreende os municípios de Cotia, Embu, Embu Guaçú, Itapecerica da serra, Juquitiba, São Lourenço da Serra, Vargem Grande Paulista e São Paulo.

Para este documento, Poder Concedente é o Estado de São Paulo, representado pela Secretaria de Estado dos Transportes Metropolitanos - STM. A Comissão Especial Julgadora de Licitação foi designada pelo presidente da EMTU/SP através do ato AP $\mathrm{n}^{\circ}$ $17 / 2005$, de 29/09/2005.

No documento está previsto a racionalização operacional do Sistema de Transporte por ônibus na RMSP, transformando-o de predominantemente radial para tronco-alimentado, cujas diretrizes estão apresentadas em um dos anexos do contrato. Coloca-se que a intenção de inclusão deste documento no edital seria de interar as licitantes da potencialidade operacional da área. Isso, entretanto, não significava naquele momento autorização das prefeituras das cidades que teriam o transporte modificado, nem mesmo um compromisso do Poder Concedente pela alteração do sistema. Como apresentado na audiência pública há um dispositivo que prevê a propositura de soluções alternativas pela concessionária, cabendo ao Poder Concedente a análise da proposta, bem como a deliberação sobre sua pertinência e relevância para a melhoria da prestação do serviço público com vistas à satisfação do usuário, ressaltando que as obras e serviços eventualmente necessários são de responsabilidade do Poder Concedente e que eventuais

conclusos no E. Tribunal de Justiça para apreciação dos embargos de declaração opostos, após decisão que negou provimento aos recursos. 
alterações propostas pela concessionária e autorizadas pelo Poder Concedente só poderiam ser implantadas após noventa dias da operação global.

Em relação à proximidade das linhas às estações de metrô da Linha 4 e ao início de operação desta, há a determinação na cláusula 1.2.1.4.1. de que o poder concedente determinará a todas as linhas de ônibus metropolitanas que tenham como destino ou prestem atendimento a um área situada na influência desta Linha, distando até quinhentos metros de seu eixo, sejam compulsoriamente secionadas na primeira estação de contato com a linha, a fim de garantir o equilíbrio econômico-financeiro do contrato.

Neste ponto, cabe observar que a previsão já no edital de uma perspectiva de construção da linha de metrô e as consequências possíveis para o concedente é importantíssima. A especulação quanto às estações existentes e os projetos já aprovados de extensão do metrô e dos trens na Região causam certo desconforto para os empresários, como posteriormente se verá também no caso da Área 5. A previsão já de que haveria esta Linha 4, cuja perspectiva de término das obras é final de 2014, e a afirmação de que haverá a manutenção do equilíbrio econômico-financeiro do contrato dão segurança para o engajamento do empresariado na obtenção da concessão, já que o prazo para o contrato é longo e nesse período não seria possível prever qual o prazo para finalização das obras e início da operação do metrô. Isso também se dá em outras possíveis implantações do sistema "sobre trilhos" que o Governo do Estado venha a implantar. Consta no edital também no anexo G-017, a título informativo, o Plano Integrado de Transportes Urbanos $(\mathrm{PITU})^{92}$, com essas possíveis implantações.

A licitação em questão compreende o serviço de operação de todo o sistema regular de transporte coletivo por ônibus e demais veículos de baixa e média capacidade e as funções de conservação, manutenção e operação da infraestrutura existente e a ser implantada na área em questão. Esta última parte corresponde também à conservação e manutenção do Terminal de Integração então existente, o Terminal de Cotia, e outros que

92 O PITU foi pensado como um processo contínuo de planejamento, pensado inicialmente para a Região Metropolitana de São Paulo e depois expandida para as demais regiões metropolitanas do estado de São Paulo. O PITU a que se refere o Edital é o PITU 2020, o primeiro pensado, realizado em 1997 e aprimorado ao longo do tempo. É interessante que a proposta dos objetivos no programa prevê uma visão futura da metrópole, seguida de objetivos da política de transporte para aquela visão e indicadores para se verificar o desempenho naquela questão. Após, foram realizados os estudos que deram origem ao PITU 2015 da Região Metropolitana de Campinas, PITU 2025 da Região Metropolitana da Baixada Santista e PITU 2025 da Região Metropolitana de São Paulo, com novos ajustes após o censo de 2000 e a vigência do Estatuto da Cidade. 
pudessem ser construídos, e à conservação e manutenção dos abrigos em pontos de parada implantados ou que fossem implementados posteriormente. Isso é relevante na medida em que aumenta os serviços a serem executados pelas empresas permissionárias, já que aumenta o escopo de trabalho a ser executado, aumentando o nível de exigência do Poder Concedente, ao mesmo tempo que aumenta a possibilidade de lucro na exploração paralela que será verificada posteriormente.

A exigência da implantação do sistema e equipamentos automatizados de controle de oferta integrados à bilhetagem eletrônica, que será parte do Sistema Metropass, é uma forma de efetivar a gestão das atividades das permissionárias durante todo o período da Concessão ${ }^{93}$. O prazo para a implantação do sistema seria de 360 dias da assinatura de termo específico e seria realizado através de consórcio entre as demais concessionárias da Região Metropolitana de São Paulo. O sistema automatizado de controle da oferta deve ser atendido com tecnologia de navegação do tipo Sistema de Posicionamento Global (GPS) ou equivalente, que fará interface com o Sistema de Gestão Técnica da EMTU - SP (GESTEC). Esta tecnologia é considerada importante para o acompanhamento em tempo real da movimentação dos ônibus, a regularidade de seus horários, a velocidade de operação, a frequência que cada ônibus passa por faixa horária, a rapidez das viagens, o cumprimento das viagens, a conservação da frota (já que poderá se contabilizar a quantidade de viagens interrompidas), a disponibilidade da frota, o conforto e economia das viagens, estas duas ultimas questões dependendo da integração dos sistemas com a bilhetagem eletrônica.

No edital, há o parâmetro para cálculo do dimensionamento da oferta de viagens e da frota necessária, o que constitui regra operacional do contrato. As condições operacionais no início da operação devem estar em conformidade com a situação de então de linhas e suas características operacionais.

Há, ainda, uma preocupação clara com horários de início e de término da jornada operacional de cada linha e também seus intervalos, lembrando que com a contratação do serviço o descumprimento de regra operacional pode culminar com a aplicação de multas.

\footnotetext{
${ }^{93}$ Deve-se lembrar, contudo, que houve a implementação parcial da bilhetagem eletrônica pelo Consórcio anterior - Consórcio de Transporte Metropolitano (CTM) -, formado pelas empresas permissionárias das linhas da Região, motivo pelo qual houve, inclusive a divulgação de troca dos créditos eletrônicos à época da transição, conforme orientação constante no anexo G-020 do Edital.
} 
Essa preocupação com horários reflete, de certo modo, uma exigência da população. A previsibilidade do tempo de embarque e desembarque do ônibus por aqueles que se utilizam do serviço público é essencial para programação daqueles que necessitam do transporte público. Ainda, a pontualidade do serviço é um atrativo para uma eventual substituição da utilização de outro meio de transporte por este, ainda que a discussão a esse respeito seja muito mais profunda que somente este ponto.

Para cumprimento das exigências do Poder Concedente quanto à frota, há uma tabela de equivalência de veículos, que deverão obedecer a certas especificações, dentre as quais a idade máxima de dez anos da fabricação do chassis para linhas comuns e seletivas e cinco anos da fabricação do chassis para linhas especiais, sendo que a idade média da frota das linhas regulares deverá ser igual ou inferior a seis anos. Essa é uma exigência muito importante que anteriormente à licitação não conseguia ser exigida de cada empresa responsável por linhas na Região. Como dito anteriormente, a idade média da frota no período anterior era de dez anos, o que aumenta a poluição causada pelos veículos, bem como pode originar maiores problemas mecânicos ao longo do contrato.

Ainda em relação à frota, esta deveria no prazo de um ano da assinatura do contrato atender a um Padrão de Comunicação Visual imposto pela Administração. Para tanto, há diversas figuras no anexo G-014 que demonstram como deverá se apresentar cada veículo, seja ele considerado leve ou médio, normal ou articulado, comum, seletivo ou especial. A padronização da aparência dos veículos auxilia a identificação da população de qual é o percurso daquele ônibus e suas condições internas, já que há variações nas acomodações entre os veículos de transporte regular. Em relação à regularização dos veículos para adequação às normativas federais ${ }^{94}$ acerca da acessibilidade de pessoas deficientes ou com mobilidade reduzida, haveria o prazo de 180 dias a partir da assinatura do contrato para que toda linha da Área possua ao menos um veículo adequado para atendimento dessas pessoas, sendo que naquele momento a área dispunha de um total de 116 linhas. Ao longo do contrato, entretanto, seria necessário a adequação dos veículos para o cumprimento integral da legislação do assunto.

A operação do serviço seria transferida à concessionária na data do contrato ou em até 180 dias após a sua assinatura, sendo este último o termo máximo para a operação global estar concluída.

${ }^{94}$ Leis $^{\mathrm{o}} 10.048$ e 10.098, ambas de 2000, e Decreto $\mathrm{n}^{\mathbf{0}} 5.296 / 04$, que regulamentou as duas primeiras. 
O valor contratual estimado do contrato é de um bilhão e quatrocentos milhões de reais, apurados como base janeiro de 2005 correspondendo a uma previsão da receita ao longo dos dez anos de contrato. As garantias aceitas são aquelas previstas na legislação (artigo 56, §1 $1^{\circ}$, da Lei 8.666/93), com a restrição de que caso a licitante opte por apresentar fiança bancária, esta deverá ser emitida por instituição financeira classificada no último Relatório dos 50 maiores bancos, critério de ativo total menos intermediação, emitido trimestralmente pelo Banco Central. É interessante observar a utilização de garantias outras que não o pagamento em dinheiro do valor, o que pode, inclusive, garantir o acesso a empresas que não poderiam dispor de grandes quantias, ainda que em um período curto.

Pelo edital, constitui receita da concessionária a tarifa paga pelos usuários, as receitas decorrentes de contratos de publicidade não vedada em lei, com critérios específicos para tanto, as receitas auferidas pela exploração comercial das áreas localizadas nos terminais metropolitanos, desde que previamente aprovada pelo poder concedente e quaisquer outras receitas, desde que autorizadas pelo Poder Concedente. Há uma restrição expressa de que a exploração comercial do Terminal Cotia somente poderia ser realizada a partir de 27/12/2009. Deve-se ressaltar que a política tarifária é definida pelo Poder Concedente e caso não haja a revisão do valor, este pode compensar de outra forma a falta de reajuste, mantendo o equilíbrio do contrato. Há a previsão expressa no Edital que por motivo de interesse público o Poder Concedente pode estabilizar ou até mesmo reduzir a tarifa.

No que diz respeito à publicidade, a EMTU regulamentou a exploração publicitária a ser realizada nos veículos, delimitando espaços para as campanhas publicitárias de forma que tal não intervenha na programação visual de identidade do transporte metropolitano. A única área interna para publicidade é o painel localizado atrás do motorista. Já na área externa, pode ser utilizada a área envidraçada traseira, com a utilização de películas perfuradas, com transparência mínima de 50\%, sendo que dez por cento da frota deverá ser destinada para divulgação de informações de caráter institucional, campanhas educativas e de utilidade pública, além de eventos culturais, beneficentes, artísticos, esportivos e científicos promovidos ou apoiados pelo Governo do Estado, pela Secretaria dos Transportes Metropolitanos ou pela EMTU/SP.

Em relação às despesas, a concessionária deve arcar com todos os custos decorrentes da execução dos serviços objeto do edital, além de outras despesas: Parcela A, 
Parcela B e o percentual de $20 \%$ sobre a receita bruta auferida em razão da exploração de contratos de publicidade, de exploração comercial das áreas localizadas nos terminais metropolitanos, e quaisquer outras receitas autorizadas pelo Poder Concedente. A Parcela A refere-se ao valor pelo gerenciamento das linhas comuns, seletivas e especiais do sistema, sendo que para cada caso há uma percentagem ou valor especificado. A Parcela B refere-se ao valor a ser pago em razão da outorga da concessão, que consiste no pagamento de percentual total da receita tarifária, nos termos da legislação vigente e da proposta realizada pelo licitante vencedor. Por esta descrição, o que se observa é que, diferente de vários municípios, que necessitam complementar a receita das empresas prestadoras do serviço de transporte, o transporte da RMSP ainda consegue que as empresas concessionárias paguem um valor, eventualmente destinado a operar melhorias no sistema para que estas possuam autorização de exploração do serviço, conseguindo também exigir alguma qualidade do serviço prestado, mostrando-se, ainda assim, atraente para o empresariado.

Como afirmado na audiência pública, a licitação em questão é uma concorrência de âmbito internacional, cujo julgamento será o de maior oferta de pagamento pela outorga da concessão, definida por parcela equivalente a um percentual da receita tarifária.

Nesse sentido, define-se a qualificação necessária dos participantes da licitação, podendo ser feito consórcio, desde que haja um compromisso de constituição do consórcio pelas empresas consorciadas, devendo todas serem solidariamente responsáveis pelos atos praticados pelo consórcio, ainda que se deva indicar a empresa líder responsável pelo consórcio e o percentual de cada componente no consórcio.

Neste caso da possibilidade de constituição de consórcio, é uma alternativa positiva para conseguir maior concorrência para as licitações de transporte público, já que muitas empresas não são suficientemente grandes para conseguir assumir todo o contrato. Para situar a discussão, deve-se lembrar que antes da licitação, haviam várias empresas responsáveis por todas as linhas da Região, seria difícil que apenas uma dessas pudesse administrar sozinha uma área completa após a divisão administrativa realizada. Inclusive, a exigência de comprovação da capacidade econômico-financeira das empresas, necessária na licitação, exclui essa possibilidade e deixa o contrato impossível para pequenas empresas. Em conjunto, entretanto, elas podem possuir o suficiente para concorrer pela 
concessão, já que para efeito de qualificação técnica é considerado o somatório dos atestados de um ou mais integrantes do consórcio e para efeito de qualificação econômicofinanceira, o somatório dos valores de cada consorciada, na proporção de sua respectiva participação.

Dentre os documentos que as licitantes devem apresentar, além das certidões de regularidade, os compromissos, as garantias e a proposta financeira, está a metodologia de execução (a ser apresentado no Envelope 1-B), no qual deve constar como os concessionários pretendem operar ao longo do contrato. Esses elementos, uma vez apresentados pelas licitantes, tornam-se obrigação contratual e eventual descumprimento pode ocasionar a aplicação de penalidades, na forma do Edital. Esses fatores a serem declarados e posteriormente avaliados na licitação são julgados pela suficiência que é medida no somatório dos índices e sua posterior divisão por 12, sendo que alguns deles possuem peso maior ou menor, de acordo com a conveniência e necessidade da Administração, mas todos devem ser apresentados pelas licitantes, sob pena de não aceitação da Metodologia apresentada e consequentemente a desqualificação da licitante. Para tal suficiência, é necessário atingir quinhentos pontos, observando a equação abaixo:

$$
S=\frac{3(\mathrm{IA})+3(\mathrm{IB})+2(\mathrm{IC})+1(\mathrm{ID})+2(\mathrm{IE})+1(\mathrm{IF})}{12}
$$

Diante disso, pode-se avaliar quais são as prioridades da licitação em questão. Verifica-se que os elementos de maior peso são o A e o B que dizem respeito ao número da frota e à idade dela. Após este critério inicial, o peso 2 é dos elementos $\mathrm{C}$ e $\mathrm{E}$ que referemse ao conforto da frota na implantação e durante toda a concessão e à acessibilidade dos veículos aos usuários portadores de deficiência ou com mobilidade reduzida. Por último, os elementos de menor peso são os $\mathrm{D}$ e $\mathrm{F}$ que dizem respeito à preocupação com o meio ambiente e ao índice de qualidade do transporte durante a concessão.

Eventual recurso dos atos da Comissão Especial Julgadora da Licitação do certame deve ser realizado no prazo de cinco dias úteis a contar da intimação do ato ou da lavratura da ata nos acasos de qualificação ou desqualificação da licitante e do julgamento da proposta financeira, sendo que nenhum prazo de recurso se inicia ou corre sem que os autos do processo estejam com vista franqueada ao interessado, de forma a garantir a ampla defesa e o direito ao contraditório. 
Após o julgamento e classificação das propostas financeiras e respectiva publicação, a comissão encaminha o processo ao Secretário dos Transportes Metropolitanos para homologar o certame e adjudicar o objeto da licitação. A partir de então, começam a contar os prazos para apresentação de frota e garagem, para o início das operações e para a operação global, ou de suas garantias na forma como previsto no edital, para posterior assinatura do contrato.

As penalidades previstas no edital são aquelas da Lei Federal $n^{\circ}$ 8.666/93, que impõe ao adjudicatário, caso este não compareça para assinar o contrato, se recusar ou não atender às condições previstas no edital neste período, a execução da garantia para licitar e a suspensão do direito de licitar e contratar com a administração pelo prazo de vinte e quatro meses, se estendendo a todas as empresas em caso de consórcio.

Após a assinatura do contrato, serão vistoriadas a frota e as garagens, sendo que as vistorias devem ser realizadas dez dias antes do início da operação, seja ela total ou parcial. Nos dez dias anteriores à vistoria, a empresa deve encaminhar os documentos e comprovantes das propriedades ou disponibilidades da frota e das garagens. O que se observa aqui é um trabalho ativo da empresa responsável pela gestão do contrato, já que essas vistorias garantem o que se tem afirmado na licitação e contrato e caso essas não representem a realidade dos fatos há os meios para executar garantias e efetuar punições.

O contrato tem previsão para ser reajustado anualmente e há a previsão de revisão contratual para recomposição do equilíbrio econômico-financeiro para algumas situações específicas, como a disparidade entre o reajuste da tarifa e os efeitos inflacionários, o incremento de ganhos da concessionária de fontes alternativas de receita e redução de custos oriundos de ganhos de produtividade gerados por fatores externos à Concessionária e modificação unilateral imposta pelo Poder Concedente que importe na variação de custos ou de receitas ${ }^{95}$. O que se observa com o detalhamento de situações é uma tentativa de abranger as situações que possivelmente possam ocorrer para garantia

\footnotetext{
95 As outras possibilidades previstas na cláusula 23.2. são: criação, extinção ou alteração de tributos ou encargos legais, de comprovada repercussão nos custos e receitas da concessionária; alteração legislativa de caráter específico, que tenha impacto direto sobre as receitas da concessionária, exceto sobre aquelas cuja concretização constitui risco exclusivo da concessionária, inclusive a que concede ou suprime isenção, redução, desconto ou qualquer outro privilégio tributário; implantação total ou parcial do Projeto da Racionalização Operacional; implantação, operação e manutenção de novos terminais e novos abrigos; implantação do Projeto Metropass; demais intervenções previstas no PITU (Plano Integrado de Transportes Urbanos) e nos sistemas municipais; integração tarifária compulsória das linhas de ônibus metropolitanas às linhas do Sistema "sobre trilhos"; introdução compulsória de outros combustíveis; surgimento de fontes alternativas de receita.
} 
tanto do Poder Concedente quanto da Concessionária, já que há uma expectativa de ganho fixa para a Concessionária, que não poderá ser maior nem menor do que o previsto.

Essa revisão eventualmente realizada será implementada por meio de alteração do valor da tarifa, pela revisão do percentual de receita auferida pela exploração comercial de áreas nos terminais e nos ônibus, pela alteração nos parâmetros operacionais, a fim de melhorar os indicadores de qualidade do transporte oferecido, antecipação na implantação dos itens oferecidos pela licitante na metodologia de execução referente aos elementos B, $\mathrm{C}, \mathrm{E}$ e $\mathrm{F}$, com vistas à melhoria na qualidade do transporte, ou a combinação dessas alternativas. Claro que não cabe a revisão caso fique caracterizado que os impactos motivadores do pedido da Concessionária pudessem ser neutralizados com a eficiente exploração do serviço ou quando decorrer de negligência, inépcia ou omissão na exploração do serviço objeto da concessão. Os pedidos devem ser fundamentados e acompanhados de relatório técnico ou laudo pericial que demonstre o impacto da ocorrência na formação dos custos ou na estimativa de receitas da concessionária. Da mesma forma, pode o Poder concedente proceder a estudos para verificação de possível necessidade de revisão, o que deve ser comunicado à concessionária, bem como aberto prazo para sua manifestação em prazo razoável.

Consta no edital a intervenção, nos termos que já estão na legislação vigente. Os meios de extinção do contrato são: (i) término do prazo do contrato, no qual seis meses antes desse prazo o Poder Concedente estabelecerá, em conjunto com a Concessionária, um Programa de Desmobilização Operacional; (ii) encampação do serviço, que será realizada por decreto do Poder Concedente e deverá ser realizada após prévio pagamento de encargos ainda não amortizados ou depreciados que tenham sido realizados pela Concessionária; (iii) caducidade, que será declarada após processo administrativo de inadimplência, garantidos o direito amplo de defesa e o contraditório ${ }^{96}$; (iv) rescisão contratual, que se dará mediante ação judicial especialmente movida para esse fim pela Concessionária $^{97}$; (v) anulação, caso em que a Concessionária será ressarcida pelo Poder

\footnotetext{
${ }^{96}$ A cláusula 33.2. prevê os casos em que o Secretario dos Transportes Metropolitanos poderá declarar a caducidade. Merece destaque a cláusula 33.3., já que determina que o processo administrativo não seja instaurado enquanto não for concedido prazo de trinta dias para que a Concessionária providencie as correções das falhas e transgressões apontadas. Esse dispositivo é mais uma garantia da ampla defesa e do contraditório.

${ }^{97}$ Neste ponto, na cláusula 34.1 do Edital, está expresso que a Concessionária não poderá interromper o serviço até 180 dias do trânsito em julgado da decisão judicial que determine a extinção do contrato, o que é, no mínimo, discutível, já que na decisão judicial poderá prever outro prazo para finalizar o serviço.
} 
Concedente dos investimentos realizados e não amortizados, desde que a concessionária não tenha concorrido para o vício do qual decorreu a anulação; e (vi) falência ou extinção da Concessionária ${ }^{98}$.

Na extinção da concessão, os bens vinculados e acrescidos reverterão ao Poder Concedente, independente de notificação ou formalidades, à exceção dos bens utilizados na operação dos serviços, quais sejam veículos e garagens. Caso haja a extinção do contrato, o Poder Concedente deverá assumir, seja direta ou indiretamente, a prestação do serviço, para garantir a sua continuidade e regularidade.

\subsubsection{Intervenção do Tribunal de Contas}

Em virtude de alguns expedientes formados a partir de representações interpostas contra os editais de concorrência das áreas $1,2,3,4$ e $5^{99}$, foi determinada pelo Tribunal de Contas do Estado de São Paulo a suspensão do certame, com o processamento da matéria como exame prévio de edital.

Anteriormente a essas representações, havia uma em específico intentada pela Empresa Expresso Regional Transportes Ltda., na qual houve a possibilidade de instauração do contraditório e posterior análise pelo Tribunal, que considerou a representação improcedente. Entretanto, considerou o relator do caso $^{100}$ que as representações posteriores indicavam a possível existência de impropriedades nos editais que poderiam acarretar restritividade ao universo de proponentes interessados em participar do certame.

A partir dessas impugnações ao Ato Convocatório, foi determinado à EMTU que procedesse as correções apontadas, o que foi cumprido. Os cinco pontos corrigidos foram os seguintes:

\footnotetext{
${ }^{98}$ Para o caso de extinção da concessionária por decretação de falência fraudulenta, ou em caso de consórcio a decretação de falência fraudulenta de um de seus integrantes e posterior extinção do consórcio em decorrência disso, aplica-se as disposições referentes à caducidade.

99 TC 32573/026/05, 33616/026/05, 33695/026/05, 33805/026/05, 33806/026/05, 33807/026/05, 33808/026/05, 33696/026/05, 33931/026/05, 34341/026/05, 34353/026/05, 34407/026/05 e 34421/026/05. A representação TC 13107/026/06 foi a última a ser intentada e posteriormente julgada.

${ }^{100}$ Conselheiro Fulvio Julião Biazzi.
} 
1) Exclusão da limitação de comprovação de qualificação técnica-profissional apenas à experiência anterior em execução de serviços de transporte coletivo urbano.

2) Modificação da redação do edital de forma a deixar clara quando devem estar disponíveis os veículos adaptados.

3) Não exigência, para fins de habilitação, de documentação de propriedade ou "compromisso de promessa" vinculada à terceiros estranhos ao certame, o que afronta as Súmulas nº 14 e 15 do TCE.

4) Exclusão da previsão do item que obriga o futuro concessionário a continuar operado após o trânsito em julgado de decisão que autorizar a rescisão contratual, contrária ao artigo 39 da Lei Federal de Concessões e artigo 25 da Lei Paulista de Concessões (Lei 7835/92).

5) Exclusão da possibilidade de encampação dos serviços por "Decreto", previsão que não respeita o disposto no artigo 37 da Lei nº 8987/95.

Posteriormente, as impugnações foram julgadas improcedentes ou parcialmente procedentes, somente para reconhecer a necessidade das mudanças incorporadas pela EMTU no curso do procedimento instaurado.

\subsubsection{Compromisso de Constituição de Consórcio}

Para concorrer à Área 1, foi formado o consórcio chamado INTERVIAS, único que apresentou proposta na concorrência em questão. Este consórcio era composto inicialmente pelas seguintes empresas: VIAÇÃO PIRAJUÇARA LTDA. (empresa líder), AUTO VIAÇÃO BRAGANÇA LTDA., VIAÇÃO MIRACATIBA LTDA., VIAÇÃO CIDADE VERDE LTDA., EMPRESA URBANA SANTO ANDRÉ LTDA. e VENEZA TRANSPORTES E TURISMO LTDA.

Com a ulterior convocação para assinatura do contrato de concessão, o Consórcio definiu sua constituição sem a participação da compromissária consorciada Empresa Urbana de Santo André Ltda., uma vez que não houve o cumprimento das obrigações assumidas pela empresa no termo de constituição de consórcio. Foi dado parecer dos membros da comissão especial julgadora de licitações no qual a exclusão da 
empresa em questão do consórcio não alterava as condições de habilitação e qualificação do licitante na concorrência. $O$ parecer jurídico dado também não verificou nenhum óbice à realização do contrato nos novos termos, já que não há vedação legal ou editalícia para tal alteração, nem há mudança na qualificação e habilitação do consórcio.

Com a informação da cisão da Auto Viação Bragança Ltda. e transferência dos serviços metropolitanos de sua responsabilidade operacional para outra empresa do mesmo grupo, qual seja Viação Raposo Tavares Ltda., em reunião extraordinária do consórcio foi aprovada a cisão pretendida e determinada a solicitação de autorização à EMTU.

Em parecer da Gerência de Assuntos Jurídicos - GAJ, verificou-se a possibilidade jurídica para tanto, restando somente necessário a apresentação de documentos que atestem o valor dos bens transferidos pela cindida à Viação Raposo Tavares Ltda., bem como seja demonstrado que as condições técnico-operacionais da nova empresa atendam às exigências precípuas do serviço, da mesma forma a regularidade fiscal da empresa cindida e a idoneidade fiscal da nova empresa.

Posteriormente, com a apresentação dos documentos requeridos, foi autorizada pelo Secretário dos Transportes Metropolitanos em exercício a cisão parcial da empresa Auto Viação Bragança Ltda. e a transferência da titularidade dos serviços por ela antes operados à Viação Raposo Tavares Ltda., com a assunção de todos os direitos e obrigações decorrentes da concessão da operação de linhas transferidas, inclusive aqueles anteriores ao ato de transferência.

\subsubsection{Avaliação da proposta}

$\mathrm{Na}$ concorrência analisada, só houve a participação de uma licitante, o Consórcio INTERVIAS. Para subsidiar o julgamento da Comissão de licitação, foi determinada a análise técnica dos atestados apresentados pela licitante, bem como da metodologia de execução proposta.

A análise técnica concluiu que a licitante não comprovou o quantitativo exigido no edital de quatro mil ônibus equivalentes por mês, conseguindo comprovar somente 3.392. Em relação à disponibilidade de veículos apresentada, esta foi considerada válida, ainda que houvesse um erro material em dois veículos relacionados, mas a 
quantidade apresentada é superior ao mínimo indicado. A metragem das áreas físicas e construídas das garagens também atenderam ao necessário previsto no edital. A metodologia de execução, apesar de algumas incorreções nos cálculos, foi aprovada, uma vez que em cada um dos elementos e no índice final obteve pontuação superior ao mínimo esperado.

$\mathrm{Na}$ ata de julgamento quanto à qualificação, foi considerada a licitante inabilitada, devido à falta de comprovação por atestados do quantitativo exigido. Por decisão da comissão, porém, foi determinada, com base no parágrafo terceiro do artigo 48 da Lei $n^{\circ} 8.666 / 93$, a apresentação de nova documentação no prazo de oito dias. Com a juntada da documentação requerida, a Comissão finalmente declarou habilitado o Consórcio INTERVIAS.

A partir disso, houve a avaliação da proposta financeira da concorrência. A licitante ofereceu o pagamento de outorga no percentual de $0,1 \%$ do total da receita tarifária. Quanto ao restante da proposta financeira, considerou-se que estaria coerente com sua proposta na metodologia de execução e de acordo com as exigências do edital, comprovando a exequibilidade do proposto. Com isso, a Comissão decidiu por classificar a proposta do Consórcio INTERVIAS, com posterior homologação do procedimento licitatório e adjudicação do objeto ao referido consórcio pelo Secretario dos Transportes Metropolitanos em 04 de julho de 2006.

\subsubsection{Ação Civil Pública}

Após a homologação do procedimento licitatório e da adjudicação do objeto ao consórcio, a EMTU foi intimada da suspensão da concorrência devido a decisão liminar em ação civil pública, proposta por MDV - Movimento em Defesa da Vida do Grande $\mathrm{ABC}^{101}$. Tal suspensão se daria até o momento em que fosse apresentado estudo prévio de impacto ambiental e relatório de impacto ambiental (EIA/RIMA) ou até o final da demanda, na ausência de tais estudos. Isso se deu com fundamento no artigo $225, \S 1^{\circ}, \mathrm{IV}$, da Constituição Federal.

\footnotetext{
${ }^{101}$ Em verdade, havia duas ações civis públicas acerca desta concorrência: 0021416-74.2006.8.26.0564 e 0024509-45.2006.8.26.0564, ambas propostas pelo mesmo autor. Em razão da similaridade das decisões, optou-se por narrar na terceira pessoa do singular.
} 
Contra esta decisão foi interposto agravo de instrumento pela EMTU ${ }^{102}$, que conseguiu liminar no Tribunal de Justiça para suspender a decisão tomada pelo juiz de primeiro grau, haja vista que a continuação do procedimento não causaria prejuízo, já que melhoraria as condições atuais das empresas de transporte ou, no máximo, não traria prejuízos maiores que aqueles observados. Posteriormente foi julgado procedente o agravo em questão para manter a suspensão da decisão liminar deferida em primeiro grau.

$\mathrm{Na}$ sentença de mérito, o processo foi julgado extinto por falta de interesse processual, já que com a suspensão da decisão anterior houve a continuidade da concorrência e ulterior assinatura do contrato. Na fundamentação da sentença, porém, consta também que não há qualquer dispositivo legal que exija a realização de estudos de impacto ambiental.

Apesar desta discussão não ter sido aprofundada na esfera judicial neste caso, cabe apresentar alguns argumentos. Deve-se destacar que, de fato, a Constituição Federal prevê em seus artigos 170 , IV e 225 , caput e parágrafo primeiro, o seguinte:

Art. 170. A ordem econômica, fundada na valorização do trabalho humano e na livre iniciativa, tem por fim assegurar a todos existência digna, conforme os ditames da justiça social, observados os seguintes princípios:

$(\ldots)$

VI - defesa do meio ambiente, inclusive mediante tratamento diferenciado conforme o impacto ambiental dos produtos e serviços e de seus processos de elaboração e prestação; (Redação dada pela Emenda Constitucional no 42, de 19.12.2003)

Art. 225. Todos têm direito ao meio ambiente ecologicamente equilibrado, bem de uso comum do povo e essencial à sadia qualidade de vida, impondo-se ao Poder Público e à coletividade o dever de defendê-lo e preservá-lo para as presentes e futuras gerações.

$\S 1^{\circ}$ - Para assegurar a efetividade desse direito, incumbe ao Poder Público:

(...)

IV - exigir, na forma da lei, para instalação de obra ou atividade potencialmente causadora de significativa degradação do meio ambiente, estudo prévio de impacto ambiental, a que se dará publicidade;

No inciso IV do artigo 225 acima, verifica-se a previsão de estudo prévio de impacto ambiental em casos de atividade potencialmente poluidora. No artigo 170, que

${ }^{102}$ Agravos de Instrumento n ${ }^{\mathrm{o}}$ 0168817-23.2006.8.26.0000 e 0170006-36.2006.8.26.0000. 
cuida dos princípios da ordem econômica, destaca em seu inciso VI a defesa do meio ambiente com tratamento diferenciado conforme o impacto ambiental. Diante disso, adotou-se o critério de maior proteção ambiental, sem custos excessivos, já que se deve considerar o porte de cada empreendimento em análise ${ }^{103}$.

O transporte coletivo por ônibus é uma atividade inegavelmente poluidora, já que os veículos se utilizam de combustíveis fósseis. Como definir, então, se seria necessária a realização do estudo prévio de impacto ambiental? Um ponto que a EMTU destacou no processo foi o fato de que a atividade de transporte metropolitano já existe, de forma que tal fato seria suficiente para a exclusão do estudo. Quer a poluição seja ou não grande, não haveria outra opção que não seja a manutenção do serviço, que é essencial em particular às famílias de baixa renda. Ainda, a existência de nova licitação seria um progresso para a diminuição da poluição, já que nos contratos antigos havia grande dificuldade em se exigir a renovação da frota, enquanto que na concorrência em questão há a imposição de adoção de novas tecnologias e renovação da frota.

Apesar das argumentações a favor da manutenção da concorrência, seria interessante verificar, diante da adoção no ordenamento jurídico vigente de uma maior proteção ambiental, que fossem realizados estudos de impacto, com a proposição constante de novas tecnologias em editais posteriores. De fato, há que se realizarem estudos para verificar os níveis de poluição e a necessidade de se exigir a utilização, ainda que gradual, de novas tecnologias para amenizar o dano ambiental característico desse serviço. Ressalte-se que em algumas áreas licitadas existem mananciais e outras áreas de proteção ambiental que deve ser preservadas.

A manutenção da liminar, com a consequente suspensão do procedimento, entretanto, traria prejuízo não só aos cofres públicos, que se obrigam a prorrogar, nesse período, contratos antigos, desatualizados e onerosos, mas também ao meio ambiente, já que os contratos antigos não possuíam exigências atuais de preocupação ambiental. É fato que a frota anterior ao contrato realizado possuía veículos em piores condições de circulação e que não garantiam acessibilidade aos portadores de deficiência. Desta forma, a manutenção da licitação trouxe melhores benefícios à população como um todo do que a espera por uma nova licitação com um estudo de impacto ambiental prévio, o que não

${ }^{103}$ Nesse sentido, Pedro de Bessa Antunes, Direito Ambiental, 14 ed., São Paulo: Atlas, 2012, p. 362. 
exclui que seja considerada a realização de tal estudo anteriormente a uma nova contratação.

\subsubsection{Contrato realizado}

$\mathrm{O}$ contrato $\mathrm{n}^{\mathrm{o}}$ 32/2006, referente à Área 1, foi assinado com o Consórcio INTERVIAS em 02 de outubro de 2006 em consonância com o já verificado no edital. Para as demais áreas as seguintes empresas foram vencedoras dos certames: Área 2 CONSÓRCIO ANHANGUERA, Área 3 - CONSÓRICO INTERNORTE e Área 4 CONSÓRCIO UNILESTE. A Área 5, como já relatado, não teve licitantes. Em 16 de novembro de 2006 teve início as operações referentes aos contratos realizados.

Tendo em vista a necessidade de escolha de linhas e assinaturas dos contratos de operação da Reserva Técnica Operacional, prevista no contrato, foram descolados setenta ORCAS, lotados na Área 1 (exceto Cotia), mais vinte ORCAS, lotados na Área 1 (Município de Cotia). O início da operação da RTO nas linhas escolhidas se deu a partir de 30 de junho de 2007.

O contrato da Área 1 até o momento teve três aditamentos, sendo que o primeiro aditamento data de 10 de setembro de 2007 e alterou o prazo para a disponibilização dos veículos adequados para a data de 31 de outubro de 2007, o que foi justificado pela falta de capacidade das encarroçadoras de efetuarem as adaptações no prazo avençado devido à grande procura por parte das empresas operadoras do sistema de transporte coletivo de passageiros por equipamentos que possibilitem acessibilidade aos usuários portadores de deficiência ou com mobilidade reduzida, motivadas pela publicação da norma ABNT NBR 14022/2006 ${ }^{104}$. Já o segundo altera a forma de cálculo do reajuste contratual. O terceiro, por sua vez, inclui a alteração do termo de constituição do consórcio, para constar que a empresa AUTO VIAÇÃO BRAGANÇA LTDA. foi cindida parcialmente e a empresa VIAÇÃO RAPOSO TAVARES LTDA. a substituiu.

\footnotetext{
${ }^{104}$ Referida norma trata da acessibilidade em veículos de características urbanas para o transporte coletivo de passageiros.
} 
O contrato analisado é controlado pelo processo $n^{\circ}$ 33702/026/06 no Tribunal de Contas do Estado de São Paulo e até o momento teve todas as contas e aditamentos realizados homologados pelo referido Tribunal.

\section{3. Área 5}

A Área 5 é operada atualmente por 16 empresas responsáveis por algumas linhas, já que até o momento não obteve êxito nas licitações propostas desde 2006. Em três delas não houve interessados e por este motivo foram canceladas e uma delas foi suspensa por decisão judicial. Nas duas primeiras licitações, admitia-se o consórcio de empresas para a execução do serviço, enquanto que nas duas últimas havia a exigência da criação de uma Sociedade de Propósito Específica (SPE), no qual apenas uma empresa responde pelas demais.

A nova licitação tem por fim a regularização da região, única que possui ainda contratos precários. Nesse contexto, há 18 empresas autorizadas que prestam serviços na região para manutenção do serviço público. A respeito da necessidade de licitação para a área há, inclusive, uma ação civil pública em trâmite perante a $8^{\mathrm{a}}$ Vara da Fazenda Pública. As dificuldades encontradas pelo Poder Público com esses contratos precários são inúmeras. Algumas delas, porém, merecem destaque. Sem um instrumento contratual preciso, há dificuldade na implementação de penalidades adequadas, bem como de estabelecer um padrão de serviço adequado e cobrar a atualização da frota das empresas, que é antiga, com veículos de idade próxima a 20 anos operando.

Foi disponibilizado para consulta pública novo edital de permissão de uso das 120 linhas da Área 5 em setembro de 2013, sendo que a audiência pública foi realizada no dia 28/11/2012, e iniciado novo procedimento licitatório, cujos contornos serão os seguintes: regime de permissão de serviço público por prazo determinado de 4 anos, prorrogável por igual período, na modalidade de concorrência internacional e o critério de julgamento será o maior valor pela outorga. O que se pode verificar da estrutura do edital é que a minuta lançada é bem mais concisa que os editais lançados anteriormente, em especial aquele analisado relativo à Área 1 . 
Um dos diferenciais do edital publicado está na idade média e individual da frota. Nos antigos editais, inclusive nos das demais áreas, a exigência da idade média da frota era de seis anos, o que passou a ser oito anos. Em relação à idade individual da frota, o tempo máximo de cada coletivo deverá ser de dez anos para veículos comuns e microônibus e de 12 anos para articulados.

Outra questão a ser destacada é que neste novo edital não há a previsão de manutenção, conservação dos terminais, para os quais haverá outra licitação distinta. Isso pode decorrer da dificuldade em se realizar contrato para esta Área. A inclusão da manutenção e conservação de terminais gera uma responsabilidade maior ao concessionário, que deveria desembolsar maior garantia para abarcar mais esse serviço.

Como nos editais anteriores, após a assinatura do contrato, o prestador de serviço terá até 300 dias para estar em pleno funcionamento, podendo a proposta estipular prazo inferior. O sistema de bilhetagem eletrônica deve estar instalado após seis meses do início da operação, com a adesão da empresa ou consórcio vencedor ao consórcio existente responsável pelo programa.

Deve-se destacar a questão do reajuste anual das tarifas. O edital estabelece esse reajuste com base na inflação medida pelo IPC/Fipe (Índice de Preços ao Consumidor, da Fundação Instituto de Pesquisas Econômicas) e em alguns variantes como mão de obra e custo do combustíveis e equipamentos, para garantia do equilíbrio econômico-financeiro do contrato. A minuta publicada do edital, no entanto, inclui a possibilidade para eventual estagnação ou redução do valor do bilhete "por motivo de interesse público relevante, desde que fique assegurada a manutenção do equilíbrio econômico-financeiro".

A partir de todas essas informações trazidas, resta fazer uma análise crítica de todo o estudado. 


\section{ANÁLISE CRÍTICA}

A partir de todo o estudado, busca-se agora elaborar uma análise crítica de todos os principais pontos.

Como já abordado, o fato da União ter instituído inicialmente as regiões metropolitanas, com previsão constitucional para tanto, resulta de uma tentativa do Governo Federal em intervir nas grandes cidades de destaque, a fim de direcionar, da forma que lhe aprazia, o desenvolvimento das metrópoles.

Isso mudou antes mesmo da Constituição de 1988, a Lei Complementar $n^{\circ}$ 14/73 já previa a competência dos Estados para a criação dos conselhos Deliberativos e Consultivos, bem como sua gerência. Ainda que seja um cenário melhor que a intervenção direta da União nas regiões, não é o ideal para o desenvolvimento da região e dos municípios dela integrantes.

A posição do Estado enquanto responsável pelas regiões metropolitanas deveria ser temporária, com a organização dos municípios para o gerenciamento de cada região, com a instituição de órgãos supramunicipais, ainda que infraestatais. Tal se daria pela necessidade de construção de algo comum e necessário a todos os municípios, como a instituição do transporte no âmbito metropolitano. Isso não deveria se dar, entretanto, a partir de modelos administrativos impostos, mas a partir da demanda específica de cada região.

Essa ideia, entretanto, dependeria de um "espírito" cooperativo dos municípios. Em termos de investimentos, ainda que se reconhecesse uma ação na região proporcional à área de cada município, a situação financeira de cada administração é distinta, o que poderia significar um desestímulo ao investimento na região metropolitana. A falta de destinação de verbas específicas é um dos problemas atuais e seria agravado pela falta de verba de alguns municípios para o investimento na região. Uma solução a esta questão seria a obrigação, cuja configuração normativa poderia ser discutida, de destinação de determinada verba dos municípios ou de porcentagem desta verba a esse fim.

Em termos políticos, com a frequente mudança de administrações e a existência de partidos diferentes no comando dos municípios, possivelmente um acordo entre eles seria de difícil consecução. Observa-se em geral uma falta de continuidade entre as administrações municipais dentro de seu próprio território. Verifica-se constantemente 
que a escolha realizada por um prefeito de uma determinada política pública que não tem continuidade por seu sucessor, seja devido às próprias convicções do homem público eleito, seja devido a pressões partidárias. No âmbito metropolitano, então, essa continuidade necessária seria ainda mais complicada de ser alcançada, haja vista a variedade de políticos e partidos a se envolverem na questão. Há, ainda, a questão dos possíveis conflitos entre os interesses da região metropolitana e os interesses dos municípios. Nem sempre tais considerações são convergentes, de forma a possibilitar uma convenção entre os municípios.

Desta forma, a existência das regiões metropolitanas a partir de um pacto entre os municípios é de difícil alcance na configuração política atual brasileira. Para alterar essa realidade, seria necessária uma mudança da mentalidade dos políticos e dos partidos para dar prioridade e continuidade aos projetos de âmbito metropolitano.

Deve-se excluir a possibilidade de criação de um ente político para a administração das regiões metropolitanas, já que o custo financeiro de tal escolha é demasiado alto e não acabaria com problemas atuais de divergências dos municípios em relação a determinadas escolhas políticas no âmbito das regiões.

Diante dessas críticas, cabe retornar à realidade apresentada neste trabalho, a fim de verificar qual a situação do transporte coletivo no cenário atual. Na Região Metropolitana de São Paulo existem basicamente três vetores de transporte: o metrô, o trem e o ônibus, sendo que os dois primeiros são modos de transporte de grande capacidade e dependem de altos investimos para criação e manutenção. O ônibus, nesse contexto, é essencial como transporte autônomo e como complementação da viagem realizada pelos modos de transporte de grande capacidade.

O transporte metropolitano, como verificado anteriormente na discussão relativa às regiões metropolitanas, não se presta a substituir o transporte municipal, nem fazer a este concorrência, já que estão expressos na Constituição a autonomia municipal e a competência dos municípios para organizar e prestar, diretamente ou sob regime de concessão ou permissão o transporte coletivo local.

Devido a este fato, maior é o interesse do município em participar da administração da região metropolitana, já que o traçado das linhas metropolitanas não deve coincidir com o das linhas municipais. Outro ponto a se destacar é a integração entre o transporte municipal e o transporte metropolitano. Ora, ainda que se possa defender que as esferas de atuação sejam distintas e que um não possa interferir no outro, o usuário do 
sistema público não deve ser prejudicado. As iniciativas para a cooperação entre o sistema municipal e metropolitano são essenciais para a melhora do serviço prestado. Com a integração física e tarifária entre os ônibus do município com os metropolitanos, a atratividade do uso dessa forma de transporte aumenta consideravelmente.

Insta destacar que as administrações de municípios pequenos, integrantes de regiões metropolitanas, podem se beneficiar de tais acordos para a realização da integração metropolitana, principalmente em relação às informações de caráter técnico, que podem ser compartilhadas.

No contexto atual, observa-se que houve uma demora considerável para viabilizar os convênios entre municípios da Região Metropolitana de São Paulo e o Governo Estadual, sendo que atualmente o bilhete eletrônico utilizado pela região (BOM) somente é utilizado nas linhas municipais dos municípios de Carapicuíba, Cotia, Ferraz de Vasconcelos, Mairiporã, Poá, Ribeirão Pires, Rio Grande da Serra, São Caetano do Sul, Suzano e Taboão da Serra. A integração tarifária, porém, não é realizada em todos esses municípios, já que é necessário convênio com o Governo Estadual e reserva financeira para tanto.

A ideia inicial da adoção do bilhete eletrônico no sistema de transporte metropolitano era que o mesmo sistema fosse utilizado por todas as cidades da região. Para a consecução desse objetivo, entretanto, há inúmeros obstáculos a serem ultrapassados. Na cidade de São Paulo, por exemplo, o bilhete único existe desde maio de 2004, mais antigo que aquele criado para a região metropolitana. A falta de compatibilidade entre os sistemas de bilhetagem eletrônica é um desses obstáculos, sendo que a pergunta a se fazer é qual dos sistemas deve se adequar: o da maior cidade da América Latina ou o da Região Metropolitana, que possui uma menor frota que a cidade em questão?

Para as cidades que não possuíam o sistema de bilhetagem eletrônica na região, a escolha pelo sistema que fosse incompatível com o sistema metropolitano pode ter cunho político. O que se observa de toda essa questão colocada sobre a integração demonstra a falta de cooperação existente e o pior desta situação é que o usuário do sistema é o maior afetado.

Sobre a questão tarifária, o que se observa do sistema metropolitano é uma variedade de preços a depender da distância a ser percorrida, a existência ou não de pedágios no caminho do ônibus e o tipo de veículo a ser utilizado, já que os do tipo comum são em geral mais baratos que os seletivos. Não se deve esquecer que a condição de ônibus 
do tipo comum pode implicar numa distância inferior e no percurso no interior das cidades, sem a utilização de vias de grande velocidade e com a possibilidade de passageiros viajarem em pé, enquanto que os do tipo seletivo, por outro lado, pode implicar em maiores distâncias e se utilizam de ônibus do tipo rodoviário. Pelas condições dos ônibus que operam as linhas seletivas, a tarifa paga pelo usuário é superior e o conforto é proporcional.

Um ponto de destaque em relação às tarifas praticadas na RMSP também é a variedade de valores, como já foi estudado. O menor valor praticado, em linha que serve Franco da Rocha e Francisco Morato, é de $\mathrm{R} \$ 2,25$, inferior à tarifa praticada pelas cidades em questão, que é de três reais. Esse valor de tarifa municipal, inclusive, é o principal praticado na região, com algumas exceções que mantém a tarifa um pouco abaixo ou acima de três reais ${ }^{105}$.

O que se observa destes fatos é que na RMSP, como não se trata de um município no qual seria necessário manter uma única tarifa, é possível garantir melhores preços a determinadas linhas, de acordo com o valor despendido para sua manutenção. Isso reflete, porém, numa variação grande de valores, sendo que a maioria das tarifas praticadas atualmente varia entre três e quatro reais ${ }^{106}$, longe dos dois reais e vinte cinco centavos da linha citada acima.

Ainda, deve-se destacar reivindicação de qualidade dos serviços prestados para a região metropolitana. Pela leitura do edital e anexos do procedimento licitatório da Área 1 da RMSP, há uma grande exigência quanto ao cumprimento de ordens e manutenção de uma qualidade mínima para todos os ônibus do sistema, o que é garantido pelas constantes fiscalizações a que as empresas contratadas são submetidas. Cabe lembrar que a qualidade, para os editais estudados, não é formada somente por uma avaliação da população, mas também por outros aspectos da prestação dos serviços: frota, operação e desempenho econômico-financeiro.

Esses meios de avaliação da qualidade do serviço são, a nosso ver, uma evolução para a verificação do aprimoramento da relação contratual entre o ente privado e o público, já que permite avaliar a contratada em seus diversos aspectos.

105 Informações quanto aos valores praticados na RMSP podem ser encontrados no site: http://mural.blogfolha.uol.com.br/2013/06/20/cidades-da-grande-sp-tambem-reduzem-tarifa-de-onibus/, acessado em 14/01/2014.

106 Os valores das tarifas praticadas podem ser visualizados no site da EMTU: http://www.emtu.sp.gov.br/emtu/itinerarios-e-tarifas/tarifas-em-formato-pdf.fss, acessado em 14/01/2014. 
No início da década de 1990, observava-se na RMSP a existência de prestadores de serviço de transporte clandestino, o que se dava também pela falta de um serviço estruturado e abrangente. A partir disso, o Governo do Estado fez um cadastramento dos veículos que faziam esse transporte e eles passaram a fazer parte do transporte regular, sendo denominados Operadores Regionais de Coletivos Autônomos ORCA. Essa iniciativa em muito contribui para o transporte regional e para a inclusão desses Operadores, que não teriam condições de concorrer para concessões mais complexas.

Em relação às Áreas 1 a 5, observa-se que houve alguma dificuldade em concretizar as concessões estudadas, o que pode estar atrelado em alguma medida à democratização da justiça. No curso dos procedimentos licitatórios, houve a proposição de ação judicial para que se exigisse um estudo do impacto ambiental que antecedesse as novas operações. Da mesma forma, as empresas que concorriam nas licitações dessas áreas também impugnaram o edital perante o Tribunal de Contas do Estado. Não se discute, aqui, se há ou não o direito de se questionar perante a Justiça Comum ou perante o Tribunal de Contas as licitações, porque é sim um direito assegurado. Isso, entretanto, pode retardar as contratações e refletir nos estudos realizados para o procedimento.

No caso da Área 1, quando da assinatura do edital, já havia passado mais de um ano dos estudos realizados e foi solicitada sua adequação para manutenção do equilíbrio econômico-financeiro do contrato. A demora na assinatura do contrato, ainda, implica num custo maior para a Administração, já que necessita muitas vezes prorrogar os contratos anteriores. Esse é o caso da Área 5, que não teve, até o momento, um contrato assinado para a exploração do serviço, mantendo as antigas permissões por linhas vigente, nas quais não há contornos contratuais que embasem exigências de melhoria da frota, por exemplo.

Para manter alguma regularidade nos contratos, a tentativa atual para a Área 5 é fazer um contrato com um prazo inferior para, quando do término dos contratos das demais regiões, fazer outra licitação, de forma a nivelar as exigências contratuais. $O$ prazo de quatro anos previsto no ultimo edital, porém, não parece ser suficiente para cobrir os 
possíveis gastos que uma empresa ou um consórcio de empresas teriam para se adaptar às exigências previstas ${ }^{107}$.

Em relação ao tipo de delegação de serviço público seria a adequada para o serviço de transporte na região metropolitana de São Paulo, entendo que não cabe a utilização do instituto da permissão, já que é do próprio contrato a necessidade de estabelecimento de datas e garantias aos contratantes, uma vez que para a realização do serviço é necessário um investimento inicial de grande monta, com a disponibilidade de grande número de ônibus, além de disponibilidade financeira para a compra ou aluguel de garagens, que devem ter uma metragem mínima, de acordo com as exigências de cada edital.

Desta forma, seriam cabíveis nos contratos de transporte metropolitano a concessão tradicional e a concessão patrocinada. O instituto da concessão tradicional, por não haver uma divisão da responsabilidade do contrato, parece ser a melhor alternativa ao ente público. Ainda que em algum momento possa ser necessária a contraprestação do Poder Público de valor para cobrir a ausência de aumento das tarifas de transporte público, esta hipótese está coberta pelo instituto, sem que seja necessário seu desvirtuamento. A contratação sob a forma de concessão patrocinada, porém, implica numa divisão de responsabilidade do contrato realizado, com a necessária contraprestação do Poder Público para complementar o valor pago a título de tarifa pelos usuários. Esse cenário não parece ser o idealizado para o sistema de transporte metropolitano de São Paulo. De outra forma, recentemente foi publicado edital de concorrência para a prestação do serviço de transporte para a Região Metropolitana da Baixada Santista, no qual há a previsão de contratação através de concessão patrocinada ${ }^{108}$.

Em relação à divisão realizada administrativamente da RMSP em cinco áreas, entendo que foi correta tal decisão por conseguir concentrar os contratos administrativos realizados, de forma a facilitar a fiscalização de execução do serviço público. Na cidade de

107 A minuta do edital da Área 5 está disponível no site da EMTU: http://www.emtu.sp.gov.br/emtu/institucional/aviso-minuta-de-edital-de-licitacao-da-area-5.fss, acessado em $14 / 01 / 2014$

${ }^{108}$ Vide minuta de edital publicada no site: http://www.emtu.sp.gov.br/ftp/edital-anexos-consulta-publica-1212-13.zip, acessado em 13/01/2014. 
São Paulo, a divisão do serviço em áreas também é realizado, contabilizando oito áreas, além do centro, que é um ponto de encontro das linhas ${ }^{109}$.

Apesar de facilitar o serviço de fiscalização, a divisão em cinco áreas diminui as possibilidades de pequenas e médias empresas de participarem da licitação, a não ser que realizem consórcios. A alteração administrativa eleita elevou o valor dos contratos e consequentemente das garantias a serem ofertadas, o que também implica num desestímulo às pequenas e médias empresas. O resultado das licitações foi a contratação de consórcios, cuja composição varia entre duas e onze empresas em cada uma.

Houve uma evolução na forma como eram feitos os contratos de concessão na RMSP. Como já foi dito, a concessão realizada em 1999 referente ao Corredor São Mateus/Jabaquara tinha como objeto também a realização de obras, bem como a administração de terminais e pontos de parada. Já as concessões realizadas em 2006 previam somente a manutenção de pontos de parada e administração de terminais, enquanto que o edital lançado em 2013 prevê somente a concessão do serviço, sem a necessidade de realizar qualquer obra ou manutenção. Com isso, pode-se concluir que há uma especialização do serviço, com a contratação de outras empresas por outros processos licitatórios para realizar obras e manutenção dos pontos e terminais de ônibus.

Como o transporte público é considerado um serviço essencial, foi criado um plano de contingência para situações de emergência. Já que a eventual paralisação de qualquer serviço do sistema pode repercutir sobre os demais, foi elaborado o PAESE Plano de Apoio entre Empresas de Transporte frente a Situações de Emergência que envolve as seguintes empresas: EMTU, CPTM, METRÔ e SPTRANS. Diante da dimensão da RMSP, a elaboração de plano para emergências é no mínimo necessário e o envolvimento de todas as empresas prestadoras do serviço de transporte é essencial para que esse plano seja abrangente e assegure à população o serviço de transporte independente de qualquer sinistro.

Um ponto importante a se analisar é a questão da proximidade entre o diferentes modos de transporte. No caso da Área 1, no início do procedimento licitatório, havia uma preocupação quanto à conclusão as obras do metrô (linha amarela), que estaria próximo a algumas das linhas concedidas. O próprio edital buscou minimizar qualquer repercussão negativa que isso viesse a causar, com a garantia de uma distância mínima do

109 A previsão da divisão em áreas está também no Decreto $\mathrm{n}^{\circ}$ 53.887/2013, disponível no site: http://camaramunicipalsp.qaplaweb.com.br/iah/fulltext/decretos/D53887.pdf, acessado em 14/01/2014. 
metrô para que não fossem alteradas as demandas existentes para o transporte da área em questão. Como já foi visto, o transporte por metrô consegue uma velocidade média superior ao transporte por ônibus e esse fato pode alterar a demanda de determinada região pela atratividade da opção mais veloz, ainda que para utilizá-lo o usuário necessite fazer um percurso a pé. Deve-se destacar que a proximidade ao metrô pode ser um desestímulo às empresas já que a remuneração dos serviços que prestam dependem do pagamento da tarifa pelos usuários e se esses escolhem outro modo de transporte há uma diminuição da receita auferida pelos concessionários do transporte por ônibus.

A respeito da padronização da aparência da frota, para a RMSP foi escolhido um padrão as linhas comuns e seletivas, o que foi criticado, uma vez que antes se poderia verificar qual seria o destino daquele veículo pelas cores adotadas em seu exterior. A nova escolha, entretanto, traça um padrão para todo o serviço de transporte, sendo de fácil identificação que aquele serviço é metropolitano, independente da cidade/rota a que se destina. Na cidade de São Paulo, como já dito, há a divisão em oito áreas e cada uma delas possui uma cor própria que auxilia na compreensão de qual região aquele veículo serve. Em relação ao município, entendo necessária essa identificação visual pela cor que faz correspondência a uma região. A relação das cores com os destinos são diferentes se analisarmos o transporte municipal e o metropolitano: o transporte municipal é o mais frequente nas ruas e avenidas das cidades, sendo que os metropolitanos significam percentagem inferior, ainda que a frota da RMSP seja a terceira maior do país ${ }^{110}$, visto que servem a mais cidades.

Em relação à percepção da qualidade do serviço, a RMSP tem valores melhores que aqueles observados para a cidade de São Paulo. Segundo pesquisa da ANTP de $2011^{111}$, o percentual de usuários que avaliam o serviço como bom ou excelente é de 51 na RMSP e de 40 na cidade de São Paulo ${ }^{112}$. Apesar de em grande parte do tempo avaliado o transporte da RMSP obter notas melhores que o da rede municipal, em dois anos esse índice foi igual ou muito próximo: 2008, com a nota de 40, e 2010, com nota de 58. Como

${ }^{110}$ Cerca de 5.500 ônibus intermunicipais em circulação diária na RMSP, segundo dados do Consórcio responsável pelo sistema de bilhetagem eletrônica, transportando mais de 5 milhões de passageiros por dia, o que representa o $3^{\circ}$ maior sistema de transporte por ônibus do país, atrás apenas das cidades de São Paulo e do Rio de Janeiro. Informação obtida no site http://www.cartaobom.net/quemsomos.aspx, acessado em $12 / 01 / 2014$

111 Pesquisa disponível no site: http://www.antp.org.br/website/produtos/pesquisa-deimagem/show.asp?ppgCode=143EB347-311A-4414-BA85-B34D2260986C, acessado em 12/01/2014.

${ }^{112}$ Para os corredores de ônibus da capital, o percentual aumenta para 54, superior ao avaliado para a RMSP. 
um comparativo de qualidade, dois outros modais disputam a primeira colocação entre os serviços de transporte da região e do município de São Paulo: o Corredor São Mateus/Jabaquara e o Metrô, com notas de 79 e 74, respectivamente. A partir dessa comparação é possível indicar que há muito a se melhorar no sistema metropolitano para alcançar a qualidade demonstradas nessas notas elevadas.

Ainda em relação a índices de qualidade avaliados pelo usuário, pelo estudo do IQC (Índice de Qualidade de Satisfação do Cliente) realizado pela EMTU, a nota para o ano de 2010 foi de 4,96 em uma escala de 0 a 10, nota inferior àquela verificada nos estudos da ANTP. Num dos atributos verificados, houve um aumento da sensação de segurança nos pontos de ônibus da RMSP que era de 4,4 em 2009 e passou a 6,5 em 2010. A esta informação, deve-se somar o fato da implantação de mais de 100 pontos de ônibus entre esses anos.

Em compensação, houve uma diminuição do atributo segurança em relação a acidentes de trânsito que era avaliado em 6,5 e passou para 4,6. Na RMSP, em 2010, verificou-se o aumento do número de atropelamentos em $28,5 \%$, totalizando o número de 126 atropelamentos contabilizados. Já os acidentes com vítima totalizaram o número de 272 em 2010, significando um aumento de $14 \%$ em relação ao ano anterior ${ }^{113}$.

Dos dados apresentados, há uma variação considerável da avaliação, com alternância em bons resultados e outros nem tão satisfatórios, de forma que não é possível avaliar uma melhora no serviço prestado. Por essa razão, a EMTU faz avaliação da qualidade do serviço com base em outros fatores, como visto acima.

Em alguma medida a situação do transporte público interfere na situação do trânsito atual nas metrópoles. Ainda que se possa considerar o transporte metropolitano como melhor que aquele municipal, muito se deve avançar para que o transporte público tenha uma qualidade tal que incentive aqueles que possuem veículo próprio a deixarem de utilizá-lo.

Alguns desincentivos ao transporte privado como aumento de tributos incidentes sobre os veículos e combustível, são interessantes para auxiliar essa transição. Essas medidas de desincentivo, entretanto, devem ser posteriores à estruturação de um transporte de qualidade e amplo suficiente para realizar seu intento.

113 Os dados expostos da EMTU podem ser visualizados na apresentação situada em: http://www.emtu.sp.gov.br/EMTU/pdf/RMSP.pdf, acessada em 12/01/2014. 
Medidas como a imposição de rodízio têm sido criticada por especialistas ${ }^{114}$ que a classificam como medida paliativa, que deve ser seguida de uma solução definitiva. O rodízio na cidade de São Paulo foi implantado em 1997 com o objetivo de reduzir a quantidade de poluentes lançados na atmosfera e acabou servindo para diminuir os congestionamentos na cidade. Passados mais de 16 anos, a quantidade de veículos emplacados na capital aumentou 37,5\%, passando de 4.735.229 em dezembro de 1997 para 7.577.216 em dezembro de 2013, segundo o DETRAN/SP, e como consequência, verificase diariamente índices enormes de lentidão e congestionamentos infindáveis.

Como a trânsito da Capital é em demasia caótico, o transporte público se perdia diante dos congestionamentos existentes. Com as manifestações de junho de 2013, uma série de medidas foram tomadas pela Prefeitura Municipal para melhorar, ainda que de forma improvisada, a rapidez do transporte público, com a implementação de faixas exclusivas de ônibus.

As faixas são de fácil aplicação, enquanto que corredores de ônibus necessitam de maiores verbas para implementação. Cabe salientar, entretanto, que as referidas ações de implementação melhoram tão somente a fluidez e rapidez das vias, não resolvendo a questão do transporte público. Apenas criar faixas exclusivas, sem introduzir mudanças substanciais na qualidade, regularidade e distribuição dos ônibus, não produzirá a mudança desejada de não apenas propiciar conforto para quem já é usuário, mas também atrair novos usuários, que hoje se deslocam em automóveis.

Deve-se lembrar que, na cidade de São Paulo, os carros particulares transportam apenas $28 \%$ dos paulistanos e ocupam cerca de $80 \%$ do espaço das vias, enquanto que os ônibus de linha e fretados, que transportam $68 \%$ da população, ocupam somente $8 \%$ desse espaço ${ }^{115}$. Diante desse quadro, vale analisar que os investimentos no transporte público são essenciais para reverter o cenário atual de congestionamentos diários e insatisfação da população. O que grande parte da população quer, e foi demonstrado pelas manifestações ocorridas em junho de 2013, é uma melhoria no transporte público, que deve ser de qualidade e acessível financeiramente a todos, bem

\footnotetext{
${ }^{114}$ Vide a crítica realizada por José de Almeida Sobrinho, presidente do conselho deliberativo do Instituto Brasileiro de Ciências do Trânsito, publicada no site: http://noticias.uol.com.br/cotidiano/ultimasnoticias/2014/01/09/rodizio-de-veiculos-e-improviso-afirma-especialista-em-transito.htm, acessado em $12 / 01 / 2014$.

115 Dados apresentados pela professora Raquel Rolnik no artigo publicado no site: http://br.noticias.yahoo.com/blogs/habitat/uma-faixa-exclusiva-\%C3\%B4nibus-incomoda-muita-gente185050379.html, acessado em 13/01/2014.
} 
como deve manter uma regularidade, com a disponibilidade de veículos para evitar a superlotação.

A breve noção de desenvolvimento sustentável explicada acima deve servir de base para que mudanças sejam realizadas na forma de se ver o transporte público, em especial aquele realizado por ônibus. Deve-se inverter o pensamento de que o transporte público é aquele utilizado por pessoas de baixa renda e incentivar sua utilização por todos. Com isso se diminuiria o uso de combustíveis fósseis, de forma que a utilização dos recursos naturais existentes seja feita de maneira sustentável, protegendo o ambiente em que vivemos. 


\section{CONCLUSÕES}

A partir de todo o estudado, conclui-se que o reconhecimento das regiões metropolitanas é a mera legitimação de uma situação de fato e representa uma evolução para o desenvolvimento do território. A competência de criação e gerenciamento inicial das regiões era da União e pode ser visto como uma forma do referido ente de intervir na organização e desenvolvimento dos principais municípios da época. Após alguns anos, porém, tal competência foi passada aos Estados, o que se mantém atualmente. Essa talvez não seja a configuração que melhor atenda às necessidades das regiões, que poderia ser administrada pelos municípios delas integrantes conjuntamente.

Nesse contexto, a Região Metropolitana de São Paulo se destaca dentre as primeiras regiões criadas e é reconhecida como a maior do país com 39 municípios integrantes, sendo que sua estrutura administrativa foi muito alterada ao longo dos anos. Atualmente, a Secretaria de Transportes Metropolitanos é a responsável pela concessão dos transportes na região, o que é feito sob o intermédio da sociedade de economia mista, a EMTU.

Como serviço público, para a concessão do transporte coletivo é necessário licitação e os tipos de contrato a serem estabelecidos são basicamente três: concessão, permissão e concessão patrocinada. Os contratos atuais da Região Metropolitana são contratos de concessão tradicional, que não preveem a contraprestação do Poder Público para sua execução, ainda que tal possa ocorrer a partir da manutenção das tarifas em valores módicos, conforme previsto nos editais e contratos assinados.

A RMSP foi dividida em cinco áreas para a contratação dos serviços a partir de cinco licitações semelhantes. Buscava-se, com isso, a melhoria dos serviços prestados a partir de melhor especialização das empresas contratadas e de fiscalização mais efetiva, com a cobrança de melhores resultados das empresas concessionárias.

O procedimento analisado neste trabalho foi o da Área 1, que abrange os municípios de Juquitiba, São Lourenço da Serra, Embu-Guaçu, Itapecerica da Serra, Embu, Taboão da Serra, Vargem Grande Paulista e Cotia. No referido processo, houve somente um consórcio concorrendo para o serviço, que ganhou a concorrência com o oferecimento do valor mínimo a ser pago a título de outorga. Da abertura do edital até a efetiva 
assinatura do contrato, entretanto, houve determinações de suspensão da concorrência, seja devido a impugnações levadas ao Tribunal de Contas do Estado, seja devido a intervenção do Poder Judiciário.

A expectativa da população quanto à execução do serviço, porém, é superior ao demonstrado mesmo após as contratações atuais. A avaliação dos usuários ainda é aquém do que se deseja e espera para o transporte público. Somente a metade dos usuários considera o serviço bom ou excelente, de forma que é possível concluir que é necessário a cobrança de melhores serviços dentro dos parâmetros contratados.

Deve-se ressaltar que o transporte público é um meio importante para inverter a realidade observada na RMSP, caracterizada pelos altos índices de congestionamentos e insatisfação da população quanto ao trânsito. A tendência atual, observada a partir dos protestos ocorridos em junho de 2013, é que a população exija melhores condições do transporte público, seja na qualidade, seja no preço da tarifa. 


\section{BIBLIOGRAFIA}

ACSElRad, Henri. Discursos da Sustentabilidade Urbana. In Revista Brasileira de Estudos Urbanos e Regionais. N 1. São Paulo, maio/1999.

ACSElRAD, HenRI. A duração das cidades: Sustentabilidade e risco nas políticas urbanas. $2^{a}$ ed. Rio de Janeiro: Lamparina, 2009.

Alochio, Luiz Henrique Antunes. O problema da concessão de serviços públicos em Regiões Metropolitanas: (re)pensando um tema relevante. In. Interesse Público, ano 5, n. 24, mar./abr. 2004. Porto Alegre: Notadez, p. 187-204.

Alonso, Ângela; e Costa, Valeriano. Dinâmica Participação em Questões Ambientais: uma Análise das Audiências Públicas para o Licenciamento Ambiental do Rodoanel, In: Participação e Deliberação: Teoria Democrática e Experiências Institucionais no Brasil Contemporâneo, 2004, p. 290-312.

Alves, AlaÔR CAFFÉ. Regiões Metropolitanas, Aglomerações Urbanas e Microrregiões: Novas Dimensões Constitucionais da Organização do Estado Brasileiro. In: Bittar, Eduardo C. B. (org.), História do Direito Brasileiro: Leituras da Ordem Jurídica Nacional. São Paulo: Atlas, 2003.

Alves, AlaÔR CAFFÉ. Planejamento metropolitano e autonomia municipal no direito brasileiro. São Paulo: Bushatsky: Emplasa, 1981.

Alves, AlaÔR CAFFÉ. A Competência Municipal e o Planejamento Metropolitano - notas sobre a possibilidade jurídica do entrosamento compulsório entre o Estado e os Municípios da Grande São Paulo para o planejamento metropolitano. In Clève, Clèmerson Merlin; Barroso, Luís Roberto (org.). Direito Constitucional: organização do Estado. Vol. III. São Paulo: Revista dos Tribunais, 2011.

Amaral Júnior, Alberto do. Comércio Internacional e a Proteção do Meio Ambiente. São Paulo: Atlas, 2011.

Antunes, Pedro de Bessa. Direito Ambiental. 14ª ed. São Paulo: Atlas, 2012.

Arantes, Otília; Cainer, Carlos; Maricato, Ermínia. A cidade do pensamento único: desmanchando consensos. $5^{\text {a }}$ ed. Petrópolis: Vozes, 2009. 
Associação Internacional de Administradores Municipais. Planejamento Urbano (trad. Modiano, Maria de Lourdes Lima). Série Administração para o Desenvolvimento. Vol. 6. Rio de Janeiro: FGV, 1965.

Associação Nacional de Transportes Públicos. Transporte humano - cidades com qualidade de vida. Coordenadores: Ailton Brasiliense Pires, Eduardo Alcântara Vasconcellos, Ayrton Camargo e Silva. São Paulo: ANTP, 1997.

Azevedo, Eurico De Andrade. Instituição de Regiões Metropolitanas no Brasil. In. Revista de Direito Público. N. 2, Ano I. São Paulo: RT, out/dez de 1967.

Bandeira de Mello, Celso Antônio. Curso de Direito Administrativo. 30a ed. São Paulo: Malheiros, 2013.

Bercovici, GiLberto. Desigualdades Regionais, Estado e Constituição. São Paulo: Max Limonad, 2003.

Bercovici, Gilberto. Soberania e Constituição: Para Uma Crítica do Constitucionalismo. São Paulo: Quartier Latin, 2008.

Berman, Harold J. Direito e Revolução: A formação da Tradição Jurídica Ocidental. São Leopoldo: Editora Unisinos, 2006.

BEYERLiN, UlRICH. "Different Types of Norms in International Environnemtal Law: Policies, Principles and Rules", in Bodansky, Daniel; Brunnée, Jutta e Hey, Ellen, The Oxford Handbook of International Environmental Law, Oxford, Oxford University Press, pp. $425-448$.

BOYLE, Alan. "Relationship between International Environmental Law and Other Branches of Law", in Bodansky, Daniel; Brunnée, Jutta e Hey, Ellen, The Oxford Handbook of International Environmental Law, Oxford, Oxford University Press, pp.125146.

Bucci, Maria Paula Dallari (org.). Políticas Públicas: reflexões sobre o conceito jurídico. São Paulo: Saraiva, 2006.

CANEver, Henrique NunEs. ADI $n^{\circ} 1.842-5 / R J$ e a visão do STF sobre regiões metropolitanas. In. Revista de Direito Público da Economia - RDPE, no 30, ano 8. Belo Horizonte: Fórum, abr./jun. 2010, p. 235-260. 
Cardoso, Carlos Eduardo de Paiva. Análise do Transporte Coletivo Urbano sob a Ótica dos Riscos e Carências Sociais. Tese de doutoramento em Serviço Social apresentada na Pontifícia Universidade Católica de São Paulo. São Paulo: 2008.

Carvalho, Vinícius Marques de. O Direito do Saneamento Básico. São Paulo: Quartier Latin, 2010. pp. 136-171.

CASTRO, MARIA BEATRIZ DE. O bonde na cidade: transportes públicos e desenvolvimento urbano. São Paulo: Annablume, 2007

Comissão de Meio Ambiente e Desenvolvimento das Nações Unidas. Nosso futuro Comum. Rio de Janeiro: FGV, 1988.

Comparato, FÁBio Konder. A Afirmação Histórica dos Direitos Humanos. São Paulo: Saraiva, 2010.

Comparato, FÁbio Konder. Ética - Direito, Moral e Religião no Mundo Moderno. São Paulo: Companhia das Letras, 2006.

Cortés, José Miguel G. Políticas do Espaço: arquitetura, gênero e controle social. São Paulo: Editora Senac São Paulo, 2008.

Costa, Adriano SoARes DA. Isenção, Serviços de Transporte de Passageiros. Características Metropolitanas. In. Revista Tributária e de Finanças Públicas, nº 49, ano 11. São Paulo: RT, março-abril de 2003, p. 115-123.

Costa, Carlos Magno Miqueri Da. Direito Urbanístico comparado: planejamento urbano - das constituições aos tribunais luso-brasileiros. Curitiba: Juruá, 2009.

DAllari, Adilson DE Abreu. Subsídios para a Criação Imediata de Entidades Metropolitanas. In. Revista de Direito Público. N. 12, Ano III. São Paulo: RT, abr/jun de 1970.

Dallari, Adilson de Abreu. O Uso do Solo Metropolitano. In. Revista de Direito Público. N. 14, Ano IV. São Paulo: RT, out/dez de 1970.

Dallari, Adílson Abreu. Parcerias em Transporte Público. In: Sundfeld, Carlos Ari (coord.). Parcerias público-privadas. 2a ed. São Paulo: Malheiros Editores, 2011. p. 380389. 
DÉAK, CsabA. Acumulação entravada no Brasil e a crise dos anos 80. In Espaço \& Debates, Neru, São Paulo, Ano X, nº 32, 1991.

DÉAK, CSABA; SCHIFFER, SUELI RAMOS (org.). O processo de Urbanização do Brasil. $2^{\mathrm{a}}$ ed. São Paulo: EDUSP, 2010.

Dias, Edna CARDOZO. Regiões Metropolitanas. In. Fórum de Direito Urbano e Ambiental, n. 37, ano 7. Belo Horizonte: Fórum, jan./fev. de 2008, p. 15-20.

Fernandes, EdÉsio. O Elo Perdido: o Desafio da Gestão Metropolitana. In: Alfonsin, Betânia de Moraes; Fernandes, Edésio. Direito Urbanístico - Estudos Brasileiros e Internacionais. Belo Horizonte: Del Rey, Lincoln Institute of Land Policy, 2006.

FERnANDES, EdÉSIO (ORG.) Direito Urbanístico. 1ª ed. Belo Horizonte: Del Rey, 1998.

FERNANDES JÚNIOR, EDÉSIO. O Ordenamento Jurídico-Institucional das Regiões Metropolitanas Brasileiras: Avaliação Crítica - Proposta de Reformulação. In. Revista de Direito Público. N. 72, Ano XVII. São Paulo: RT, out/dez de 1984.

Ferraz, Antonio Clóvis "CocA" Pinto e Torres, IsAac Guillermo EsPinosa. Transporte Público Urbano. $1^{\text {a }}$ ed. São Paulo: do Autor, 2001.

FERraZ, SÉRgio. As Regiões Metropolitanas no Direito Brasileiro. In. Revista de Direito Público. N. 37-38, Ano VII. São Paulo: RT, jan/jun de 1976.

Frúgoli Júnior, Heitor; Andrade, Luciana TeiXeira de; PeiXoto, Fernanda ArêAs (org.) As cidades e seus agentes: práticas e representações. Belo Horizonte: PUC Minas/Edusp, 2006.

Furtado, Celso. Formação Econômica do Brasil. São Paulo: Companhia das Letras, 2007.

GORNI, DANIEL. Modelagem para operação de bus rapid transit. Dissertação (Mestrado) Escola Politécnica da Universidade de São Paulo. Departamento de Engenharia de Transportes. São Paulo:2010.

Grau, ERos Roberto. Regiões metropolitanas: regime jurídico. São Paulo: Bushatsky, 1974.

Grau, Eros Roberto. Direito Urbano: regiões metropolitanas, solo criado, zoneamento e controle ambiental. São Paulo: Revista dos Tribunais, 1983. 
Grau, Eros Roberto. A Ordem Econômica na Constituição de 1988. 14ª ed. São Paulo: Malheiros, 2010.

Grau, Eros Roberto. Constituição e Serviço Público, in Grau, Eros Roberto e Guerra Filho, Willis Santiago (coord.), Direito Constitucional, estudos em homenagem a Paulo Bonavides, São Paulo, Melheiros, 2001.

Guimarães, Jackson Rocha; Silva, Gutemberg da Mota E. Serviços Comuns Metropolitanos e Autonomia Municipal. In. Revista de Direito Público. N. 73, Ano XVIII. São Paulo: RT, jan/mar de 1985.

Hardin, GarretT. The Tragedy of the Commons, Science, v. 162, no. 3859 pp. 1243$1248(1968)$.

HAYeK, Friedrich August Von. Competition as a Discovery Process, In: The Quarterly Journal of Austrian Economics, v. 5, no. 3, 2002, pp. 9-23

Holanda, Sérgio Buarque De. Raízes do Brasil. 26a ed. São Paulo: Companhia das Letras, 1995.

Horta, Raul Machado. Direito Constitucional. 5a ed. Belo Horizonte: Del Rey, 2010.

Horta, Raul Machado. Regiões Metropolitanas e Direito Constitucional. In Clève, Clèmerson Merlin; Barroso, Luís Roberto (org.). Direito Constitucional: organização do Estado. Vol. III. São Paulo: Revista dos Tribunais, 2011.

IngRAmi, Mario. Aspetti del Problema delle Grandi Concentrazioni Urbane. Milano: Giuffrè, 1974.

KowARICK, Lúcio. O preço do Progresso: Crescimento Econômico, Pauperização e Espoliação Urbana. In. Moisés, José Alvaro; Kowarick, Lúcio; Valladares, Lícia do Prado; Nunes, Edison; Evers, Tilman; Muller-Plantenberg, Clarita; Spessart, Stefanie; Jacobi, Pedro. Cidade, Povo e Poder. Rio de Janeiro: Paz e Terra, 1982.

Labate, MARCElo Luiz. Transporte Sustentável como fator essencial para a qualidade de vida: o caso de São Paulo. Tese de doutoramento apresentada à Faculdade de Arquitetura e Urbanismo da Universidade de São Paulo. São Paulo: 2006.

LEFEBVRE, HENRI. A Revolução Urbana. Belo Horizonte: UFMG,1999. 
Lima, Paulo B. De AraúJo. As Regiões Metropolitanas e seus aspectos institucionais. In. Revista de Direito Administrativo. Vol. 129. Rio de Janeiro: FVG, jul/set de 1977.

MARICATO, ERMÍNIA. Urbanismo na periferia do mundo globalizado: metrópoles brasileiras. Disponível em http://dx.doi.org/10.1590/S0102-88392000000400004. Acesso em $22 / 11 / 2011$.

MARICATO, ERMiniA. Metrópoles desgovernadas, Estudos Avançados, vol. 25, n. 71, jan/abr de 2011.

Marques, José Roberto. Meio Ambiente Urbano. 2a ed. Rio de Janeiro: Forense Universitária, 2010.

Meirelles, Hely LoPes. Direito Municipal Brasileiro. 14 a ed. São Paulo: Malheiros, 2006.

MeIRELles, Hely LoPES. Direito Administrativo Brasileiro. 35ª ed. São Paulo: Malheiros, 2009.

Mencio, Mariana. Considerações Jurídicas sobre as Constituições Estaduais que introduzem o Plebiscito e o Referendo como instrumentos de Participação Popular no Processo Legislativo de Criação das Regiões Metropolitanas. In. Boletim de Direito Administrativo, ano 28, n. 4, abr. 2012. São Paulo; NDJ, p. 427-446.

MuKAI, ToshIO. Direito e Legislação Urbanística no Brasil: história, teoria, pratica. São Paulo: Saraiva, 1988.

Mukai, Toshio. O Regime Jurídico Municipal e as Regiões Metropolitanas (conforme Emenda Constitucional n. ${ }^{\circ}$ 1/69). $1^{\text {a }}$ ed. São Paulo: Sugestões Literárias, 1976.

Munhoz, DANIEla CORdeIRo DE FARIAS. Regiões Metropolitanas. In. Dallari, Adilson Abreu; Di Sarno, Daniela Campos Libório. Direito Urbanístico e Ambiental. Belo Horizonte: Fórum, 2011.

Nunes, Avelãs. Industrialização e Desenvolvimento - A Economia Política do "Modelo Brasileiro de Desenvolvimento”. São Paulo: Quartier Latin, 2005.

Ostrom, ElinOR. Governing the Commons: The Evolution of Institutions for Collective Action, Cambridge, Cambridge University Press, 1990, pp. 1-28. 
Pedreira, Christina DE AlmeidA. Instrumentos legítimos à Implementação das competências constitucionais administrativas comuns. In. Revista Brasileira de Estudos Constitucionais - RBEC, n. 6, ano 2. Belo Horizonte: Fórum, abr./jun. 2008, p. 19-48.

PhilipPi JR., Arlindo; Alves, AlaÔR CAFFÉ (editores). Curso Interdisciplinar de Direito Ambiental. Barueri: Manole, 2005.

Prado JÚnior, CAIO. Formação do Brasil Contemporâneo (Colônia). 6 ${ }^{\mathrm{a}}$ ed. Ed. Brasiliense, 1961.

RaiA JÚNIOR, ARChIMEdes AZEvedo. Acessibilidade e Mobilidade na estimativa de um índice de potencial de viagens utilizando redes neurais artificiais e sistemas de informações geográficas. Tese (doutorado) - Universidade de São Paulo. São Carlos, 2000.

Reale, Miguel. Política e direito: Ensaios. São Paulo: Saraiva, 2006.

RoncA, Jose LuIz CARuso. Urbanização no Brasil: seus fatores preponderantes, sua interação com o desenvolvimento. Dissertação (mestrado) - Universidade de São Paulo. São Paulo, 1979.

Rosas, Roberto. Perspectiva Jurídica da Região Metropolitana. In. Revista de Direito Público. N. 28, Ano VII. São Paulo: RT, mar/abr de 1974.

SACHS, JEFFREY. Common Wealth: Economics for a Crowded Planet, 2008, pp. 57-137.

SAntos, Gervásio Ferreira DOS. Política energética e desigualdades regionais na economia brasileira. Tese (Doutorado) - Universidade de São Paulo, 2010.

SAntos, Milton. A Urbanização Brasileira. 5ª ed. São Paulo: EDUSP, 2009.

Salomão Filho, CaliXto. Historie Critique des Monopoles: une Perspective Juridique et Économique. 1. ed. Paris: LGDJ, 2010.

Salomão Filho, Calixto; Ferrão, Brisa lopes de Mello; e Ribeiro, IVAn César. Concentração, Estruturas e Desigualdade: As origens coloniais da pobreza e da má distribuição de renda, São Paulo, Idcid, 2006.

SEn, Amatya. Desenvolvimento com o Liberdade. São Paulo: Companhia das Letras, 2000.

Serrano, Pedro Estevam Alves Pinto. Região Metropolitana e seu regime constitucional. São Paulo: Verbatim, 2009. 
Silva, Almiro do Couto E. Região Metropolitana: Fundação criada por Estado e Municípios. In. Revista de Direito Público. N. 28, Ano VII. São Paulo: RT, mar/abr de 1974.

Silva, José Afonso DA. Direito Urbanístico Brasileiro. 6ª ed. São Paulo: Malheiros, 2010.

Silva, José Afonso. Curso de Direito Constitucional Positivo. $35^{\mathrm{a}}$ ed. São Paulo: Malheiros, 2012.

SilveirA, TÁcito PIO DA. Chicago; São Paulo: contribuição ao estudo do transporte coletivo no processo de urbanização. Dissertação de mestrado área de concentração Planejamento Urbano e Regional FAUUSP. Orientadora Klara Anna Maria Kaiser Mori. São Paulo: 2008.

STERn, Nicolas. "Executive Summary of The Economics of Climate Change", disponível no site da internet http://siteresources.worldbank.org/INTINDONESIA/Resources/2262711170911056314/3428109-1174614780539/SternReviewEng.pdf

Taller, Adriana; Antik, AnAlíA. Curso de Derecho Urbanístico. $1^{\mathrm{a}}$ ed. Santa Fé: Rubinzal-Culzoni, 2011.

TeiXeira, Ana CAROlina WANDERley. Região Metropolitana - instituição e gestão contemporânea - dimensão participativa. Belo Horizonte: Fórum, 2005.

VASCONCELlOS, EDUARDO AlCÂNTARA. Circular é preciso, viver não é preciso.A história do trânsito na cidade de São Paulo. São Paulo: Annablume/Fapesp, 1999.

VAsCOnCEllos, EduARDo AlCÂNTARA. Transporte urbano, espaço e equidade: Análise das Políticas Públicas. São Paulo: Annablume, 2001.

Wald, ARnoldo. As áreas Metropolitanas. In. Revista de Direito Público. Ano 5, Vol. 22. São Paulo: RT, out/dez de 1972.

WEISS, EDITH BROWN. "Global environmental change and international law: The introductory framework", in Weiss, Edith Brown (ed.), Environmental Change and International Law - New Challenges and Dimensions, New York, The United Nations University Press, 1992, pp. 3-38. 


\section{RESUMO}

As regiões metropolitanas surgiram a partir do desenvolvimento do modo de produção capitalista do século XX e tiveram seu reconhecimento em textos normativos a partir da Constituição de 1967. A Constituição de 1988 coloca a cargo dos Estados a eventual instituição de regiões metropolitanas. A Região Metropolitana de São Paulo foi criada com a Lei Complementar $n^{\circ}$ 94/74, antes mesmo da atual constituição. A delegação e fiscalização do transporte público metropolitano da região estão a cargo da Secretaria de Transportes Metropolitanos. O transporte público coletivo é considerado um serviço público e, como tal, deve obedecer a algumas regras para sua delegação a terceiros (empresas privadas), o que se pode dar por concessão, permissão ou concessão patrocinada. A remuneração da prestação do serviço público se dá, em geral, pelo pagamento de tarifa, mas pode abranger também um pagamento do Poder Público para viabilizar o negócio. Da mesma forma, pode o concessionário ou permissionário necessitar pagar um valor referente ao custo da outorga e a custos gerenciais. O transporte público é essencial para a circulação nas cidades, o que garante maior acessibilidade e mobilidade principalmente à população de baixa renda. Vários são os modos de transporte público, sendo que o ônibus é o mais comum e que demanda menores investimentos. A delegação do serviço de transporte coletivo na Região Metropolitana de São Paulo foi dividida em cinco áreas para maior controle do Estado sobre a execução dos contratos, sendo que somente quatro delas possuem contratos a partir de licitações iniciadas em 2005. Escolheuse o procedimento realizado para a Área 1 para estudo, em vista da similaridade dos procedimentos referente às demais áreas. Apesar das diversas tentativas de contratação de empresas para a execução do serviço na Área 5, até o momento todas as tentativas foram fracassadas. Por fim, segue-se a uma análise crítica de todo o estudado.

PALAVRAS-CHAVE: transporte público, ônibus, região metropolitana, Região Metropolitana de São Paulo, delegação de serviço público 


\begin{abstract}
The metropolitan regions emerged from the development of the capitalist mode of production of the twentieth century and had its normative recognition in the 1967 Constitution text. The 1988 Constitution places the responsibility of the states to possible imposition of metropolitan regions. The Sao Paolo Metropolitan Region was created by the Complementary Law $n{ }^{\circ} 94 / 74$, even before the current constitution. The delegation and supervision of the metropolitan public transport in the region are made by the Secretariat of Metropolitan Transport. The public transportation is considered a public service and, as such, must obey some rules for its delegation to third parties (private companies), which can be given through a concession, permission or sponsored concession. The remuneration of the public service implementation is made by the bus fare, but may also involve a payment from the Government to enable the business. Likewise, the company may pay an amount related to grant and management costs. Public transport is essential for the movement in the cities, which ensures greater accessibility and mobility mainly to lowincome population. There are several modes of public transportation, and the bus is the most common and lower investment demand. The delegation of the public transport service in Sao Paolo Metropolitan Region is divided into five areas for greater state control over the contracts implementation, and only four of them have contracts from bidding started in 2005. We chose the procedure performed for Area 1 for study in view of the similarity of procedures regarding other areas. Despite several attempts to hiring companies for the execution of the service in Area 5, so far all attempts failed. At the end it's made an critic analysis of what was studied.
\end{abstract}

KEYWORDS: public transportation, bus, metropolitan region, Sao Paolo Metropolitan Region, delegation of public service 